\title{
UTILIZAÇÃO DE DGPS COMO GUIA PARA DISTRIBUIDORES A LANÇO
}

\section{EDMILSON RENATO SILVA RUIZ \\ Engenheiro Agrônomo}

Orientador: Prof. Dr. José Paulo Molin

\begin{abstract}
Dissertação apresentada à Escola
Superior de Agricultura "Luiz de Queiroz", Universidade de São Paulo, para obtenção do título de Mestre em Agronomia. Área de Concentração:

Máquinas Agricolas.
\end{abstract}

PIRACICABA

Estado de São Paulo - Brasil

Agosto - 1999 
Dados Internacionais de Catalogação na Publicação (CIP) DIVISĀO DE BIBLIOTECA E DOCUMENTAÇĀO - Campus "Luiz de OUEiroz"/USP

Ruiz, Edmilson Renato Silva

Utilização de DGPS como guia para distribuidores a lanço / Edimilson Renato Silva Ruiz. - P Piracicaba, 1999.

74 p. : il.

Dissertação (mestrado) - - Escola Superior de Agricultura Luiz de Queiroz, 1999.

Bibliografia.

1. Adubo 2. Agricultura de precisão 3. GPS 4. Insumo agricola 5. Manejo do solo 6. Mecanização agricola 7. Prática cultural I. Titulo

CDD 631.3 


\section{UTILIZAÇÃO DE DGPS COMO GUIA PARA DISTRIBUIDORES A LANÇO}

Aprovada em: Agosto/1999

Comissão Julgadora

Prof. Dr. José Paulo Molin

ESALQ/USP

Prof. Dr. Luiz Antônio Balastreire ESALQ/USP

Prof. Dr. Kléber Pereira Lanças FCA/UNESP

Prof. Dr. José Paulo Molin Orientador 


\title{
DEDIDO
}

\begin{abstract}
Aos meus pais, João Ruiz e Neuza Ruiz, pelo esforço, almejando um futuro brilhante a seus filhos.
\end{abstract}

\begin{abstract}
À minha mãe Neuza Maria da Silva Ruiz, pelo amor, carinho, compreensão, incentivo e por tudo que aprendi para superar todas as dificuldades encontradas nesta vida, $\underline{\boldsymbol{O F E R E C} \boldsymbol{C}}$.
\end{abstract}




\section{AGRADECIMENTOS}

A Deus, por todas as coisas que a vida nos mostra para podermos crescer como pessoa.

Ao Prof. Dr. José Paulo Molin, pela amizade e orientação na realização deste trabalho.

Aos professores responsáveis pelas sugestões e orientação na execução desta Dissertação.

À CAPES, Coordenação e Aperfeiçoamento de Pessoal de Nível Superior, pela concessão de bolsa de estudos.

A todos os professores e funcionários do Departamento de Engenharia Rural, pelos ensinamentos e cordialidade.

Ao grande amigo Juan Bonnin e sua esposa Glória Bonnin, por todos os momentos agradáveis que passamos nesta etapa da vida.

A Dr ${ }^{3}$. Adriana M. M. Pires, pelo companheirismo, incentivo e ajuda na realização deste trabalho, agradeço.

Ao amigo Dr. Dumas V. Casagrandi e Rose A. Casagrandi (in Memorian), pela ajuda e apoio na superação de um obstáculo encontrado.

Aos amigos Fernando Pascholatti, Sérgio Carvalho, Remi Dambrós, Atílio, Ezer, Heitor e Danilo, pela amizade e por tornar o ambiente de trabalho mais agradável.

A todos os colegas do Curso de Máquinas Agrícolas da turma de 1998: Moizéis Nery, Sergio Pereira, Maurício De Leon, Wagner Campaner, João, Tachibana, Ricardo, Pedro, Flávio e Leite.

A Márcia C. Ricci, pelo carinho, compreensão, apoio e por todos os momentos difíceis até a realização deste trabalho.

A todas as pessoas que direta ou indiretamente contribuíram para a realização deste trabalho, agradeço. 


\section{SUMÁRIO}

pág.

1 INTRODUÇÃO

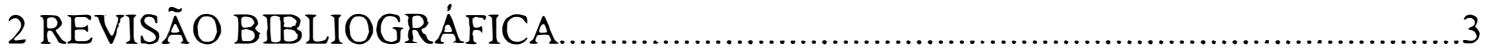

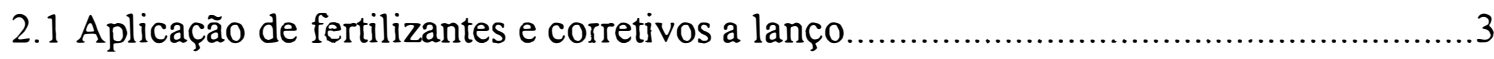

2.2 Caracterização da qualidade de distribuição em máquinas a lanço..............................7

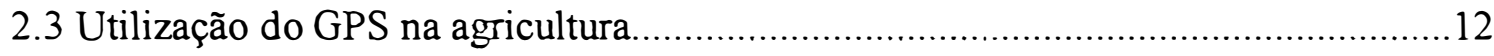

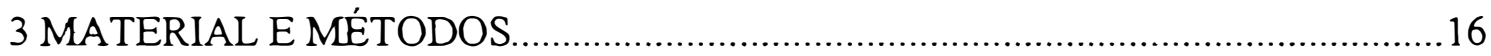

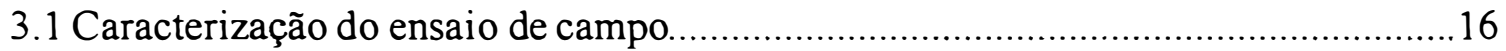

3.2 Ensaios de caracterização de distribuição transversal e longitudinal.........................19

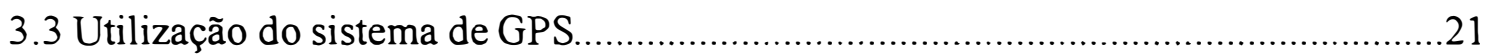

3.4 Interação da análise de erro de percurso ao desempenho da máquina.......................26

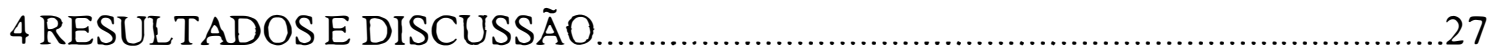

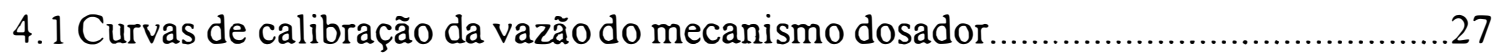

4.2 Caracterização dos fertilizantes e corretivos utilizados...........................................28

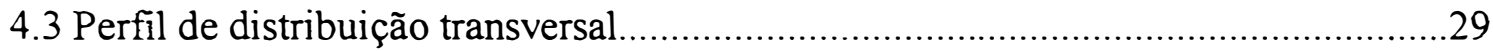

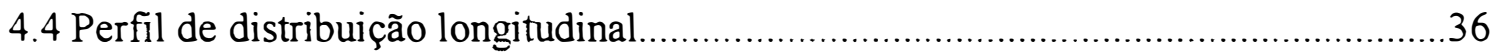

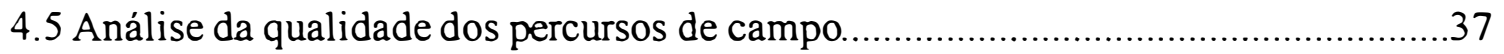

4.6 Análise da influência da qualidade de percurso nas aplicações a lanço......................44

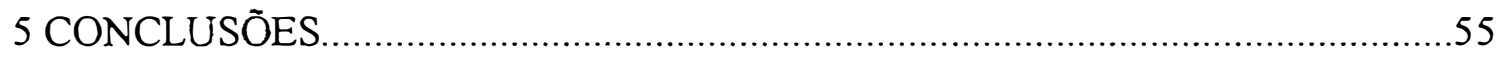

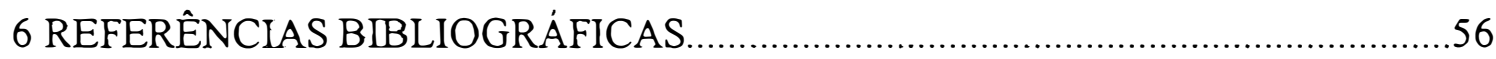

APÊNDICES 


\section{LISTA DE TABELAS}

pág.

TABELA 1. Configuração da barra de luz para os ensaios

TABELA 2. Caracterização básica dos operadores envolvidos nos ensaios. .25

TABELA 3. Quadro de análise de variância dos ensaios de qualidade dos percursos....26

TABELA 4 Características físicas obtidas em laboratório para os fertilizantes e corretivos utilizados nos ensaios.

TABELA 5. Largura efetiva de trabalho em função dos valores fixados para o coeficiente de variação de $12,5 \%, 15,0 \%$ e $20,0 \%$

TABELA 6. Estatística descritiva do perfil de distribuição longitudinal... 37

TABELA 7. Composição da variância do resultado da análise do DGPS. 39

TABELA 8. Média dos erros no deslocamento para as duas velocidades testadas com e sem a barra de luz ativada por DGPS.

TABELA 9. Estatística descritiva da frequência de erro

TABELA 10. Efeito do percurso com e sem o sistema de orientação e do erro assim gerado, nas velocidades de deslocamento de $2,20 \mathrm{~m} \mathrm{~s}^{-1}$ e $3,75 \mathrm{~m} \mathrm{~s}^{-1}$, com probabilidade de $50 \%$ e $90 \%$, na qualidade da distribuição transversal de calcário, expressa pelo seu coeficiente de variação.

TABELA 11. Efeito do percurso com e sem o sistema de orientação e do erro assim gerado, nas velocidades de deslocamento de $2,20 \mathrm{~m} \mathrm{~s}^{-1}$ e $3,75 \mathrm{~m} \mathrm{~s}^{-1}$, com probabilidade de $50 \%$ e $90 \%$, na qualidade da distribuição transversal de adubo, expressa pelo seu coeficiente de variação 48

TABELA 12. Efeito do percurso com e sem o sistema de orientação e do erro assim gerado, nas velocidades de deslocamento de $2,20 \mathrm{~m} \mathrm{~s}^{-1}$ e $3,75 \mathrm{~m} \mathrm{~s}^{-1}$, com 
probabilidade de $50 \%$ e $90 \%$, na qualidade da distribuição transversal de uréia, expressa pelo seu coeficiente de variação.........................................51

TABELA 13. Efeito do percurso com e sem o sistema de orientação e do erro assim gerado, nas velocidades de deslocamento de $2,20 \mathrm{~m} \mathrm{~s}^{-1}$ e $3,75 \mathrm{~m} \mathrm{~s}^{-1}$, com probabilidade de $50 \%$ e $90 \%$, na qualidade da distribuição transversal de aveia, expressa pelo seu coeficiente de variação .53

TABELA 14. Caracterização do ambiente durante a realização dos ensaios 67

TABELA 15. Resultados das medições de deslocamento entre a linha base e a posição em que o trator passou para cada tratamento dos ensaios de percurso com sistema de orientação de DGPS .68

TABELA 16. Resultados das medições de deslocamento entre a linha base e a posição em que o trator passou para cada tratamento dos ensaios de percurso sem sistema de orientação de DGPS

TABELA 17. Média dos posicionamentos do trator em relação a linha base para cada tratamento no ensaio de caracterização do percurso 70 


\section{LISTA DE FIGURAS}

pág.

FIGURA 1. Tipos de percurso de campo: A - Perimétrico; B - Altemado.....................

FIGURA 2. Características do equipamento utilizado nos ensaios.............................. 17

FIGURA 3. Posicionamento padrão das aletas para calcário........................................ 18

FIGURA 4. Posicionamento padrão das aletas para adubos e sementes........................18

FIGURA 5. Passagem do distribuidor sobre os coletores durante os ensaios.................20

FIGURA 6. Componentes utilizados nas aplicações em faixas paralelas de marca

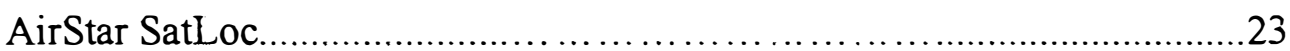

FIGURA 7. Simulação das aplicações em faixas paralelas.........................................23

FIGURA 8. Curvas de calibração de vazão do mecanismo dosador para os quatro

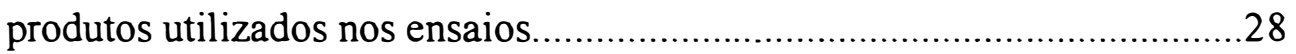

FIGURA 9. Perfil de distribuição transversal dos diferentes tratamentos: distribuição de calcário, adubo, uréia e aveia nas velocidades de $2,20 \mathrm{~m} \mathrm{~s}^{-1}$ e 3,75 $\mathrm{m} \mathrm{s}^{1}$

FIGURA 10. Resultados simulados do coeficiente de variação como função da largura efetiva para os diferentes métodos de percurso possíveis para cada tratamento. 33

FIGURA 11. Perfil de distribuição longitudinal de calcário e adubo granular para as duas velocidades testadas .36

FIGURA 12. Análise da dispersão dos pontos gerados a diferentes tempos de permanência sobre num mesmo ponto. 
FIGURA 13. Desvio do trator em relação à linha desejada com percurso de 2,20 $\mathrm{m} \mathrm{s}^{-1}$

FIGURA 14. Desvio do trator em relação à linha desejada com percurso de 3,75 $\mathrm{m} \mathrm{s}^{-1}$

FIGURA 15. Probabilidade de erro a $2,20 \mathrm{~m} \mathrm{~s}^{-1}$ em relação ao percurso. 43

FIGURA 16. Probabilidade de erro a $3,75 \mathrm{~m} \mathrm{~s}^{-1}$ em relação ao percurso 43

FIGURA 17. Percursos observados pelo operador 1 a velocidade de deslocamento de $2,20 \mathrm{~m} \mathrm{~s}^{-1}$ e $3,75 \mathrm{~m} \mathrm{~s}^{-1}$, com e sem o uso da barra de luz .70

FIGURA 18. Percursos observados pelo operador 2 a velocidade de deslocamento de $2,20 \mathrm{~m} \mathrm{~s}^{-1}$ e $3,75 \mathrm{~m} \mathrm{~s}^{-1}$, com e sem o uso da barra de luz 71

FIGURA 19. Percursos observados pelo operador 3 a velocidade de deslocamento de $2,20 \mathrm{~m} \mathrm{~s}^{-1}$ e $3,75 \mathrm{~m} \mathrm{~s}^{-1}$, com e sem o uso da barra de luz 72

FIGURA 20. Percursos observados pelo operador 4 a velocidade de deslocamento de $2,20 \mathrm{~m} \mathrm{~s}^{-1}$ e $3,75 \mathrm{~m} \mathrm{~s}^{-1}$, com e sem o uso da barra de luz .73

FIGURA 21. Percursos observados pelo operador 5 a velocidade de deslocamento de $2,20 \mathrm{~m} \mathrm{~s}^{-1}$ e $3,75 \mathrm{~m} \mathrm{~s}^{-1}$, com e sem o uso da barra de luz. .74 


\title{
UTILIZAÇÃO DE DGPS COMO GUIA PARA DISTRIBUIDORES A LANÇO
}

\author{
Autor: Edmilson Renato Silva Ruiz \\ Orientador: Prof. Dr. José Paulo Molin
}

\section{RESUMO}

A aplicação de insumos a lanço guiada por barra de luz governada por DGPS é uma prática inédita na agricultura brasileira. O presente trabalho se propõe a quantificar o erro no deslocamento no campo de um conjunto trator mais aplicador a lanço com e sem o uso deste recurso. Os objetivos do trabalho foram: a) levantar as curvas de deposição transversal de um distribuidor a lanço de mercado; b) desenvolver uma metodologia para medir o erro no deslocamento guiado por DGPS e aplicá-la em ensaios de campo; c) quantificar a qualidade de deposição considerando o erro de posicionamento da barra de luz e o sistema convencional sem orientação.

A primeira etapa do trabalho visou caracterizar as curvas de deposição transversal de um distribuidor de arrasto, de mercado, para os quatro produtos: calcário, uréia, aveia e adubo granular. Os ensaios foram realizados seguindo a norma ISO 5690/1, em duas velocidades de trabalho: $2,20 \mathrm{~m} \mathrm{~s}^{-1}$ e $3,75 \mathrm{~m} \mathrm{~s}^{-1}$. Os dados foram obtidos pela passagem do distribuidor sobre os coletores dispostos lado a lado. Com a utilização do programa Adulanço 2.0, foram feitas análises para a determinação do coeficiente de variação como função da largura efetiva. 
A segunda etapa do trabalho visou propor e testar um metodologia de campo para se determinar a qualidade de alinhamento e paralelismo no deslocamento de um trator guiado por DGPS, comparando-o com o deslocamento sem orientação. Para a demarcação dos percursos utilizou-se uma barra porta ferramentas suportando um disco de corte liso que fazia a demarcação do solo. Em percursos de $200 \mathrm{~m}$ o operador se localizava através de uma linha base com estacas a cada $50 \mathrm{~m}$. Após a passagem pela linha base o operador realizava três novas passadas com espaçamento de $5 \mathrm{~m}$, simulando uma aplicação. Após a passagem do conjunto marcando o solo, utilizou-se um teodolito para fazer a marcação de uma reta de $200 \mathrm{~m}$. Com uma trena fez-se marcações a cada 10 $\mathrm{m}$, totalizando 20 pontos. O delineamento experimental utilizado foi de blocos casualizados, utilizando um fatorial $2 \times 2$ para velocidade $\left(2,20 \mathrm{~m} \mathrm{~s}^{-1}\right.$ e $\left.3,75 \mathrm{~m} \mathrm{~s}^{-1}\right) \mathrm{e}$ equipamento (com DGPS e sem DGPS), em cinco blocos representados por 5 operadores e quatro tratamentos, totalizando 20 parcelas.

A terceira etapa consistiu em quantificar a qualidade de deposição dos diferentes produtos com base nas curvas de deposição e erro de deslocamento utilizando ou não a barra de luz.

Através do levantamento das curvas de deposição transversal, observou-se que com o aumento da velocidade de $2,20 \mathrm{~m} \mathrm{~s}^{-1}$ para $3,75 \mathrm{~m} \mathrm{~s}^{-1}$, ocorreu maior variação no perfil de distribuição para adubo e uréia. No caso de calcário e aveia, a velocidade de deslocamento não influenciou no perfil de distribuição. Os resultados mostraram que a barra de luz como guia para aplicações em faixas paralelas, apresentou menor erro no deslocamento durante os percursos em comparação com o sistema sem orientação. No entanto, ambos os sistemas deixaram a desejar em termos de qualidade de alinhamento. Como consequência o coeficiente de variação das faixas de aplicação variaram enormemente, comprometendo a qualidade da aplicação. Um maior treinamento dos operadores e ajustes na barra de luz devem produzir melhores resultados com a utilização desta técnica. 


\title{
DGPS USE AS A GUIDE FOR SPREADER APPLICATORS
}

\author{
Author: Edmilson Renato Silva Ruiz \\ Adviser: Prof. Dr. José Paulo Molin
}

\section{SUMMARY}

The use of a DGPS as a guiding system for ground application is still not in use in the Brazilian agriculture. This work ames to quantify the displacement error of a tractor simulating swath application with and without the use of a light bar as guidance.

The objectives were: i) obtain the transverse curves a spinner box spreader machine with four products; ii) developed a methodology to measure the displacement error when using DGPS as a guidance and test it in the field; iii) quantify product deposition error caused by traveling errors with and without DGPS.

The first stage consisted in characterizing the deposition curves for four products: lime, urea, oat seeds and granular fertilizer. The tests were conducted with a commertial spinner box according to the ISO 5690/1 standard at two speeds: $2,20 \mathrm{~m} \mathrm{~s}^{-1}$ and 3,75 $\mathrm{m} \mathrm{s}^{-1}$. After passing over the collectors the product was waighed and than the data was analised using a program called Adulanço 2.0 to determinate the coefficient of variation as a function of the effective width.

The second part os the work consisted in testing a methodology to determine the alignment quality and parallelism in a tractor guided by DGPS and without any guidance. A flat coulter disk supported by a tool bar was used to mark the soil as the 
tractor passed. The operator simulated swathing applications $5,0 \mathrm{~m}$ wide starting from a base line made of aligured stakes $50 \mathrm{~m}$ aparth $200 \mathrm{~m}$ long lines. After that a theodolit was used to trace a straight line. Every $10 \mathrm{~m}$ its was measured the displacement betwen the two lines (real and theoriction), totalizing 20 points on each line.

A statistical analisys was conducted using a fatorial scheme $2 \times 2$ for speed $(2,20$ $\mathrm{m} \mathrm{s}^{-1}$ and $3,75 \mathrm{~m} \mathrm{~s}^{-1}$ ) and equipment (with DGPS and without DGPS), in five blocks represented by 5 operators.

The third part consisted in quantifing the deposition quality of the four products based on the deposition curves and displacement error for the two guiding conditions. It was observed that increasing for word speed increased the variation in the profile distribution for fertilizer and urea. For lime and oat seeds, speed did not affect the distribution profile. The results showed that DGPS as guidance for applications in parallel swaths, presented smaller displacement error in comparison to the system without orientation. Both systems resulted in high coefficient of variation resulting in low quality applications. Operators with more training and ligth bar setup adjustments may provide better results. 


\section{INTRODUÇÃO}

A aplicação de insumos como corretivos, fertilizantes e sementes em superficie é prática comum na agricultura brasileira. Essa é normalmente executada por vários tipos de máquinas, com diferentes princípios de funcionamento e formas construtivas. A escolha ou a recomendação de uma delas vai depender de vários aspectos relativos à máquina, ao produto a ser aplicado e ao tipo de exploração agrícola.

A produtividade das culturas, como em qualquer setor da produção resulta da atuação integrada de diversos fatores. Os fertilizantes e corretivos são fatores que exercem influência muito significativa na produtividade final. A obtenção de resultados positivos com o uso do calcário agrícola está diretamente associado a alguns fatores básicos como: qualidade do corretivo, época de aplicação, uniformidade de distribuição e incorporação do produto.

Com o avanço tecnológico, os agricultores estão em busca de alternativas para melhorar o aproveitamento do potencial dos solos e consequentemente o aumento da produtividade, através das aplicações de insumos. Tendo surgido como mais uma alternativa de otimização na produção agrícola, a agricultura de precisão, recentemente vem tomando espaço nos países mais desenvolvidos. Trata-se de uma forma de manejo diferenciado do solo e da cultura, para a adequar as diferentes condições encontradas em cada pedaço de lavoura.

A agricultura de precisão teve sua viabilização em escala comercial com a disponibilização do sinal de GPS. O GPS ou "Sistema de Posicionamento Global", desenvolvido pelo Departamento de Defesa dos Estados Unidos como um sistema de navegação por satélites, deixou de ter a importância que tinha ao fim da guerra fria. $O$ 
GPS chegou à agricultura, como uma sofisticada ferramenta de trabalho disponivel e de grande utilidade para proporcionar a acelerada expansão das técnicas de agricultura de precisão. Paralelamente, outras aplicações para o GPS vêm surgindo no meio agrícola. Uma delas é sua utilização como guia para aplicação em faixas paralelas.

A prática da utilização de DGPS como guia em passadas paralelas vem sendo utilizada na aviação agrícola brasileira. Com a popularização da utilização do DGPS e sua disponibilização em propriedades agricolas, especialmente em práticas ligadas à agricultura de precisão, sua adoção poderá ser intensificada em outras aplicações. $\mathrm{O}$ uso de barra de luz como guia em passadas paralelas é uma dessas utilizações alternativas.

Devido a aplicação de insumos a lanço guiada por barra de luz governada por DGPS ser uma prática inédita na agricultura brasileira, o presente trabalho se propõe a explorar sua viabilidade técnica quando aplicada em um conjunto trator mais aplicador de insumos a lanço. Sendo assim, os objetivos principais do trabalho são:

- levantar as curvas de deposição transversal de um distribuidor a lanço de mercado;

- desenvolver uma metodologia para medir o eno no deslocamento guiado por DGPS e aplicá-la em ensaios de campo;

- quantificar a qualidade de deposição considerando o erro de posicionamento do DGPS e o sistema convencional, sem orientação. 


\section{REVISÃO BIBLIOGRÁFICA}

\subsection{Aplicação de fertilizantes e corretivos a lanço.}

Muitos trabalhos que estimam a porcentagem dos custos operacionais da principais lavouras paulistas mostram que os gastos com fertilizantes e corretivos são altos, variando conforme a cultura. Camargo et al. (1981), por exemplo, encontraram resultados que variam de $12 \%$ para o amendoim e $37 \%$ para o sorgo. Já Siqueira (1989), estimou que o custo das principais culturas de grãos variam entre 30 a $50 \%$.

Há uma preocupação em toda as áreas relacionadas com o processo de produção agrícola no sentido de aumentar a eficiência de utilização de diversos insumos (Lopes, et al., 1985). Para reduzir estes gastos, uma opção é melhorar as estimativas das necessidades de adubação e calagem, evitando utilizar estimativas grosseiras da otimização econômica da produção agrícola (Colwell, 1985 e Peres et al., 1985).

Os critérios para recomendação de adubação devem discriminar as situações em que haja resposta à aplicação de fertilizantes. Para muitas culturas a análise de solo fornece parâmetros adequados para a recomendação de fósforo e potássio, porém, para o nitrogênio esta técnica, em geral, não apresenta resultados satisfatórios (Raij, 1981).

Os fertilizantes e corretivos agrícolas constituem insumos fundamentais na exploração agropecuária. A correta aplicação destes na operação comumente denominada "adubação" assume particular significado, tanto pela forma como as plantas respondem essa prática como pelos custos envolvidos ( Milan e Gadanha Jr, 1996). De acordo com Luz (1989), na época estimava-se que $72 \%$ das aplicações de corretivos eram realizadas à lanço e $28 \%$ eram feitas por meio de distribuidores em linha. 
Tourino, (1986) explica que no caso de adubadoras a lanço, a aplicação de quantidades excessivamente altas em uma parte de parcela e quantidades muito baixas em outras partes provocam consideráveis perdas em produtividade, rendimento e qualidade na colheita.

A utilização de corretivos no controle da acidez do solo, segundo Luz (1989), é uma prática que vem se consolidando no meio agrícola. A mecanização dessa operação, se difundiu muito nesses últimos anos. Conforme Carvalho e Chalfoun (1991), a prática da calagem também controla parcialmente a ocorência e severidade das doenças, modificando o meio de tal forma que proporciona um maior ou menor desenvolvimento de microrganismos patogênicos às plantas. $O$ conhecimento dos aplicadores de corretivos é de fundamental importância, visto que existem diferentes opções de equipamentos à disposição do produtor.

Sabe-se que a adubação nitrogenada é essencial para a obtenção de boa produtividade na agricultura (Anghinoni, 1985 e Almeida, et al., 1985). No entanto, há necessidade de uma abordagem mais ampla no estudo do nitrogênio, visando melhor conhecimento do sistema e, com isto, tomar possível um manejo mais adequado dos solos e dos fertilizantes para um aumento na eficiência de sua utilização (França et al., 1985).

A uréia que vem sendo amplamente utilizada como fonte de nitrogenada requer uma atenção especial quanto a forma e época de aplicação, de maneira a assegurar a sua eficiência (Cooke, 1985).

Braga (1991), explica que a granulometria indica a capacidade do corretivo reagir no solo e envolve tanto a velocidade de reação quanto seu efeito residual. A granulometria dos corretivos, define a área de contato e portanto quanto mais fino o corretivo, mais rápida é sua ação (Alcarde, 1985). O efeito residual de um corretivo é o tempo de duração da calagem efetuada (Silva et al., 1991).

Bellingieri et al. (1989) afirmam que o teor de neutralizantes é fundamental, porém, devido a baixa solubilidade em água dos corretivos, a granulometria assume papel importante, uma vez que a sua dissolução fica na dependência do contato com o solo. 
Utilizando dois tipos de calcários, o dolomitico e o dolomitico calcinado, verificaram que com a uilização do calcário dolomitico calcinado houve um aumento de $14 \%$ na produção de grãos, melhorando as propriedades químicas do solo com as granulometrias mais finas (Bellingieri et al., 1992).

Uma maneira de aumentar esta eficiência é fazer um planejamento da aplicação. Por exemplo, para aplicação de calcário Quaggio (1986) cita que a desuniformidade de distribuição e de incorporação dos corretivos são as principais causas que contribuem para menor resposta à calagem no primeiro ano.

Entre as principais máquinas utilizadas para aplicação de fertilizantes e corretivos sólidos são citadas por Gadanha Jr. et al. (1991) como sendo a aplicadora de fertilizantes e corretivos a lanço, de linhas individuais, de linhas conjugadas, aplicador de corretivo em linha e transportadora aplicadora autopropelida de fertilizantes e corretivos.

O mecanismo dosador é o conjunto de elementos que tem por finalidade controlar o fluxo de saída do corretivo do depósito para o mecanismo distribuidor. As máquinas equipadas com mecanismos dosadores volumétricos são aquelas que provem a retirada contínua de um determinado volume de material do reservatório, e cuja vazão é regulada por uma chapa raspadora que limita a altura do produto junto a saída do reservatório. Já para as máquinas montadas, o mecanismo dosador é gravitacional, utilizando aberturas reguláveis com auxílio de um agitador. O mecanismo distribuidor é um conjunto de elementos, que tem por objetivo promover a distribuição do produto, oriundo do dosador. Por se tratar do principal elemento de constituição dos aplicadores de corretivos responsável pela faixa de deposição ou aplicação, o mecanismo distribuidor é o critério usado para agrupar os equipamentos para qualquer finalidade de análise, pois, o comportamento das curvas de aplicação por tipo de distribuição é semelhante (Luz, 1989).

Sabe-se que no Brasil, os mecanismos distribuidores especificos para aplicação de corretivos em superfície, são basicamente os de queda livre, centrifugos de rotores e os pendulares ou inerciais. 
Segundo Gadanha Jr. et al. (1991) os distribuidores centrifugos são caracterizados por utilizarem um ou dois rotores (discos), com aletas fixas ou não para o lançamento do produto.

Parish (1995a) explica que os aplicadores pendulares são considerados como os que oferecem maior vantagem sobre os aplicadores centrifugos, devido melhor uniformidade de distribuição.

Segundo Mialhe (1986) as máquinas para aplicação a lanço são constituídas basicamente por um chassis, reservatório e mecanismos dosador e distribuidor do produto. Estes últimos são os principais componentes dos distribuidores a lanço pois tem a função de dosar e distribuir a quantidade pré-selecionada de produto aplicado.

A forma do disco tem efeito na distribuição centrífuga de calcário seco. O ângulo de posicionamento das aletas afeta o seu desempenho, interferindo na simetria e no coeficiente de variação do perfil de distribuição transversal, assim como na largura de trabalho (Dallmeyer, 1985; ; Hofstee e Huisman, 1995).

A caracterização do desempenho de uma máquina aplicadora de fertilizantes e corretivos a lanço é feita por meio de uma série de ensaios. Dentre eles Mialhe (1996) cita os ensaios das características dimensionais e ponderais, ensaio do equipamento do ponto de vista de segurança, ergonomia e funcionalidade mecânica e ensaios das características de desempenho em laboratório e campo: regularidade da vazão, faixa de distribuição transversal e longitudinal.

De acordo com Balastreire e Coelho (1992) a aplicação mecanizada de corretivos tem como fatores limitantes as características físicas do produto, principalmente no que se refere a granulometria e teor de umidade. Assim sendo, quanto menor o tamanho das partículas e, quanto mais úmido o produto, maior dificuldade as máquinas aplicadoras têm em dosar e distribuir adequadamente o mesmo. Mialhe (1996) explica que as características do material influem no desempenho do equipamento de aplicação e para tanto devem ser avaliadas. Nessas características inclui-se a granulometria, densidade, teor de água e ângulo de repouso.

Hofstee e Huisman (1990) explica que a performance dos distribuidores de fertilizantes e conseqüente a regularidade da aplicação, depende muito das propriedades 
fisicas dos produtos. Com base nesta informação, Hofstee (1992) avaliou métodos para medir o coeficiente de fricção, resistência aerodinâmica e resistência à quebra das partículas. A partir disto, Hofstee e Huisman (1994) avaliaram uma nova técnica de medição da velocidade de partículas de fertilizantes, através da técnica baseada em amplitude instantânea e frequência.

Mialhe (1996), explica que a regularidade da vazão pode ser verificada para diversas regulagens de abertura do mecanismo dosador e com diferentes produtos. Com o reservatório abastecido, aciona-se o mecanismo e coleta-se o material em um período de tempo não menor que 30 segundos. $\mathrm{O}$ material coletado é pesado e calcula-se a vazão. Essa avaliação pode ser efetuada com o reservatório abastecido a diferentes níveis para a verificação da regularidade da vazão em função da quantidade de produto disponivel no reservatório.

A aferição da velocidade operacional é de fundamental importância, pois se a mesma estiver acima da velocidade necessária, para uma dada vazão, a dosagem será menor do que a desejada. Caso contrário, quando a velocidade operacional for menor do que a necessário, para a mesma vazão, a dosagem final será maior do que a desejada (Balastreire e Coelho 1992).

\subsection{Caracterização da qualidade da distribuição em máquinas a lanço.}

Vários autores sugerem metodologias diferentes para a realização de ensaios de caracterização da faixa de distribuição transversal.

O ensaio segundo Mialhe (1996), deve ser efetuado em área com superficie horizontal e plana. No caso de local aberto, recomenda que a velocidade do vento não ultrapasse a $2 \mathrm{~m} / \mathrm{s}$. Os coletores devem apresentar dimensões padronizadas de $1000 \mathrm{x}$ $250 \mathrm{~mm}$ ou $500 \times 500 \mathrm{~mm}$, com profundidade mínima de $150 \mathrm{~mm}$. Devem ser utilizados dispositivos que evitem o ricochete do material na superficie, sendo recomendada a divisão do coletor em células de 50 × $50 \mathrm{~mm}$ ou a colocação de uma cobertura do tipo rede ou um filme plástico, conforme recomenda a norma ISO 5690/1. 
Para autores como Dallmeyer (1985), Fontana et al. (1985), Luz (1986), Spugnoli et al. (1989) e Parish (1996) ensaios de regularidade de distribuição podem ser realizados com diferentes tipos de coletores, tendo diversas dimensões variando entre $400 \times 400 \mathrm{~mm}, 400 \times 600 \mathrm{~mm}, 250 \times 500 \mathrm{~mm}$.

Durante a realização dos ensaios, de acordo com Luz e Tourino (1986), faz-se passar o distribuidor em funcionamento sobre uma fila de coletores, os quais devem ser dispostos lado a lado, de tal modo que fíquem perpendiculares ao eixo de deslocamento do distribuidor.

Whitney et al. (1987), comparando diferentes alturas do mecanismo distribuidor em relação aos coletores dispostos em concreto durante a aplicação de uréia, verificaram que as alturas iguais ou superiores que $0,61 \mathrm{~m}$ não mostraram alterações com o aumento do material nos coletores, devido ao ricochete das partículas.

Whitney et al. (1992) utilizando grama sintética como coletor superficial, observaram maior eficiência quando comparados com os coletores conforme norma da ASAE S341.1.

Parish (1996) através de testes realizados conforme norma da ASAE S341.2 utilizando quatro produtos granulares para determinação na eficiência da coleta, verificou que houve aumento de distribuição nos extremos dos coletores com a utilização de grânulos com partículas maiores.

De acordo com Molin (1991), o uso de abafador ou cortinas para evitar a deriva é válido, porém fixam a largura efetiva de trabalho. Isso não significa que a distribuição sob o abafador estará sendo uniforme.

De acordo com Mialhe (1996) a avaliação da distribuição longitudinal tem como finalidade determinar as características de distribuição do equipamento ao longo da linha de deslocamento da máquina. Os coletores são dispostos em linha simples no sentido de deslocamento da máquina, entre as rodas do conjunto.

Para se ter um bom planejamento de aplicação é essencial a avaliação da deposição cumulativa. Numa determinada aplicação de campo, esta avaliação depende do tipo de percurso adotado no manejo da máquina. Num circuito contínuo, o lado esquerdo, de parte da faixa de deposição numa passada, recobre o lado direito de parte 
da faixa de deposição da passada anterior. No circuito vai e vem, o lado direito de parte a faixa de deposição numa passada, recobre o lado direito de parte da faixa de deposição da passada anterior. O mesmo acontece também com o lado esquerdo, e assim sucessivamente, como mostra a Figura 1.

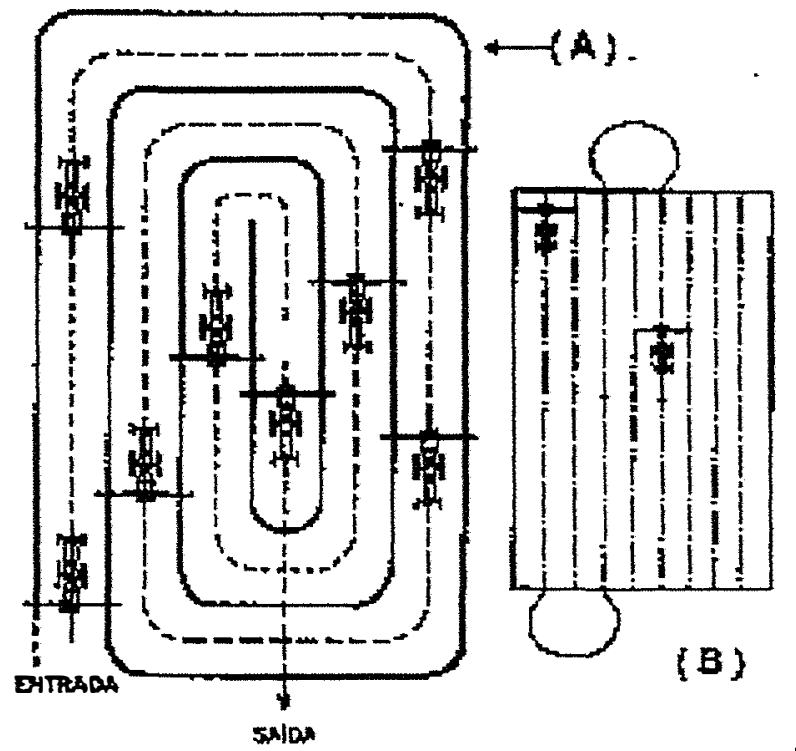

FIGURA 1. Tipos de percurso de campo: A -Perimétrico; B - Alternado; adaptado de Coelho et al. (1992).

O efeito causado em termos de aumento de produtividade ou prejuízo devido a utilização de uma largura irregular de trabalho, podem ser revistos através do coeficiente de variação (England \& Audsley, 1987).

O coeficiente de variação definido como a razão entre o desvio padrão e a média aritmética é uma porcentagem cujo o cálculo é utilizado para comparar o desvio médio e a média. Campos (1984) realizou ensaios agrícolas de campo e afirma que coeficientes de variação entre 10 e 20 \% são considerados normais. Já Pimentel (1987) explica que valores para o coeficiente de variação de $10 \%$ são considerados baixos, entre 10 e $20 \%$ médios e 20 e $30 \%$, altos, e maiores que $30 \%$ muito altos. Pimentel (1991) salienta que o número de repetições influi nos valores de coeficiente de variação, sobretudo pelo fato que, mesmo havendo um coeficiente de variação maior em relação ao outro que, porém, 
possui menor número de repetições, aquele com maior coeficiente de variação seria considerado o mais preciso.

Balastreire e Coelho (1992) explica que para determinar a largura útil, deve-se proceder colocando recipientes padrões (latas de óleo, ou bandejas padronizadas com dimensões conhecidas), espaçadas a cada $50 \mathrm{~cm}$. A partir disto, passar com a máquina operando à velocidade, rotação e abertura do regulador de vazão recomendada, 5 vezes no mesmo sentido. Desta maneira, após gerar gráficos do perfil de distribuição, separar os gráficos em duas metades, colocando-se metade à direita de frente para a metade à esquerda, de forma que as pontas dessas metades se toquem. Em seguida, mover metade da direita sobre metade da esquerda e calcular o coeficiente de variação das quantidades entre os dois centros da faixa até que este esteja ao redor de $30 \%$. Anotando o número de recipientes e multiplicando por $50 \mathrm{~cm}$, resulta na largura útil.

O procedimento normalmente utilizado para a determinação da largura efetiva baseia-se no coeficiente de variação $(\mathrm{CV})$. Para tanto realiza-se a simulação de recobrimentos sucessivos com os valores obtidos nos coletores e calcula-se o CV \% para cada situação de recobrimento simulado para a determinação da largura efetiva. Os valores de $\mathrm{CV} \%$ para as diferentes larguras efetivas simuladas podem ser então plotados. O compromisso entre um valor baixo de $\mathrm{CV} \%$ e um valor prático para a largura é que efetivamente deverá ser utilizada no campo.

Delafosse e Boglian (1989) sugerem outra forma, além do coeficiente de variação, para se avaliar a sobreposição e escolher a que resulta na distribuição mais uniforme. Após a coleta e pesagem do material é feita a simulação de diferentes sobreposições. Consideram que a sobreposição pode ser considerada aceitável quando os resultados da curva de deposição ficam dentro de uma variação de $+/-30 \%$ em torno da média.

Silva et al. (1990) avaliando um distribuidor pendular de fertilizantes, elaboraram um modelo matemático para prever a largura da faixa e a freqüência de distribuição dos fertilizantes. Com isso, em termos gerais o modelo conseguiu simular a faixa de deposição da máquina, embora o pico na extremidade tenha apresentado uma diferença muito grande, entre o valor simulado e o experimental. 
Molin et al. (1992), propuseram um programa desenvolvido principalmente para o processamento dos dados de ensaios da análise de distribuição transversal de material. O ADULANÇO 2.0 é utilizado na análise de dados de máquinas aplicadoras de corretivos, fertilizantes e sementes a lanço, mas pode ser utilizado para simulação de sobreposições nos ensaios de bicos de pulverizadores ou outros similares.

Anderson et al. (1990) desenvolveram um programa para microcomputador onde a partir dos dados obtidos em ensaios de campo simula o desempenho da máquina, verificando a curva de distribuição ideal (largura efetiva) do equipamento. A análise baseia-se na escolha da sobreposição de faixas a qual proporciona uma curva de distribuição com menor coeficiente de variação.

Parish (1995b) sugere que a largura da faixa de aplicação de um aplicador pendular, pode ser calculada adequadamente, simplesmente medindo a largura total da faixa e dividindo por dois.

Yule et al. (1996) utilizando coeficiente de variação de $29 \%$ verificaram sérios problemas com algumas áreas de trigo quando aplicado $40 \%$ a mais de fertilizantes nitrogenados que o recomendado. Observaram que o uso excessivo de fertilizantes pode causar acentuada perda de produtividade.

Spugnoli et al. (1989) em testes de distribuição de fertilizantes, utilizando uréia e fertilizante granular (10.10.21), observaram resultados de coeficiente de variação variando entre 42 a $55 \%$ para faixas de aplicação de 7,0 m. A obtenção de altos valores de coeficiente de variação, foram devido a influencia das características do equipamento testado e as características fisicas dos produtos.

Analisando a uniformidade de semeadura de arroz com um distribuidor centrífugo de disco cônico, Fontana et al. (1985) verificaram que utilizando um coeficiente de variação de $18 \%$, obtiveram uma largura de trabalho de 14,0 m com boa simetria. 


\subsection{Utilização do GPS na agricultura.}

O sistema GPS ou "Global Positioning System" foi desenvolvido pelo Departamento de Defesa dos E.U.A. Trata-se portanto de um sistema militar altamente estratégico, todavia com potencial muito grande para as aplicações civis. O setor civil passou a ter acesso a essa tecnologia a partir de meados da década de setenta, quando universidades e instituições de pesquisa puderam então investigar e inclusive, colaborar no aperfeiçoamento do sistema (Vettorazzi et al., 1994).

O GPS é um sistema que georeferencia o usuário para a sua perfeita localização na superficie da terra. Na agricultura o GPS vem permitindo a utilização de novos conceitos e práticas que deram origem à chamada agricultura de precisão.

Segundo Han et al. (1995), o sistema GPS é formado por uma constelação de 24 satélites, dos quais 21 encontram-se ativos e 3 de reserva, emitindo sinais que são captados em terra por receptores de GPS. Utilizando o processamento de sinais captados, o receptor calcula sua posição.

Balastreire (1998b) explica que os satélites transmitem os sinais para o posicionamento em duas frequências, chamadas de L1 e L2. A portadora L1 é modulada por uma sequência de pulsos que recebe o nome de código C/A ("Coarse/Acquisition"). A portadora L2 gera apenas o código $\mathrm{P}$, sendo utilizado apenas por receptores autorizados. A utilização dos sinais Ll e L2 e os códigos transmitidos por eles gera 0 Serviço de Posicionamento Preciso (PPS) o qual permite aos usuários uma acurácia de posicionamento horizontal de $22 \mathrm{~m}$ e vertical $27,7 \mathrm{~m}$ durante $95 \%$ do tempo. Já para os demais civis utilizam o Serviço de Posicionamento Padrão (SPS) e permite uma acurácia horizontal de $100 \mathrm{~m}$ e vertical de $156 \mathrm{~m}$ durante $95 \%$ do tempo.

A precisão dos receptores hoje disponíveis no mercado e de uso em agricultura de precisão varia em tomo de 1 a 5 metros. No entanto, essa precisão só é possivel com o uso de DGPS (Molin, 1998a). O DGPS ou GPS diferencial é um método largamente utilizado na correção de erros. Esse nada mais é que um sinal adicional de um ponto referencial em uma base fixa. Stafford (1996) explica que os erros de posicionamento dos receptores terrestres incluem o erro de retardo de sinal causados pela ionosfera e 
troposfera, o erro do relógio do satélite, efeméride, órbita e ruído dos receptores. A correção destes erros ou DGPS podem ser em tempo real ou em pós processamento.

Balastreire (1998b) explica que os sinais de correção podem ser transmitidos por pelo menos quatro métodos: estação de rádio "beacon", estação terrestre fixa, estação de rádio via FM e satélites geoestacionários. No Brasil as técnicas de correção diferencial (DGPS), disponíveis até o momento são por meio de uma estação local e via satélite.

Para a correção em pós-processamento, utilizada quando não há comunicação entre os receptores fixo e móvel, os dados dos erros podem ser coleados pelo receptor base e transferidos posteriormente via disquete, para um computador, juntamente com os dados de posições coletadas pelo GPS móvel, a fim de que seja feita a correção diferencial dos dados (Balastreire et al., 1997).

Hoje a utilização do sinal de GPS é extremamente diversificada e chegou a agricultura, proporcionando a acelerada expansão das técnicas de agricultura de precisão. Balastreire (1994) explica que o termo "aplicação localizada de insumos", é utilizado na agricultura de precisão como forma de se caracterizarem ações realizadas sobre pontos específicos da área, cujas coordenadas, latitude e longitude, sejam conhecidas.

A decisão sobre a melhor altemativa de gerenciamento localizado da cultura poderá ser grandemente auxiliada pela utilização de software específicos de Sistemas de Informações Geográficas - GIS, desenvolvidos para agricultura. Esses fornecerão como produto final um mapa de aplicação localizada de insumos, o qual poderá ser lido regulando automaticamente a aplicação da quantidade requerida naquele local (Balastreire, 1998a).

Uma ferramenta útil que utiliza GPS é a chamada barra de luz. Foi desenvolvida para servir como um guia para o operador em aplicação de produtos em faixas paralelas. Foi originalmente concebida para guia em aplicações aéreas, visando eliminar a necessidade de sinalizadores ou bandeirinhas. Porém, já está sendo proposta para substituir o uso de marcadores de espuma ou mesmo discos marcadores em operações como aplicação de defensivos, fertilizantes e corretivos a lanço e semeadura, 
especialmente em plantio direto. Consiste em um sinal luminoso posicionado na frente do operador que o orienta a manter uma dada direção (Molin, 1997).

Fekete (1997) analisando o erro de localização usando DGPS, observou através de testes, que o DGPS pode ser usado para medir a velocidade de deslocamento com um erro máximo de $0,1 \mathrm{~m} / \mathrm{s}$. Além disso, utilizando velocidades de deslocamento que variam de 3,6 a $19 \mathrm{~km} / \mathrm{h}$, observou um desvio lateral de $0,58 \mathrm{~m}$ em percursos em linha reta de $400 \mathrm{~m}$.

Zuydam et al. (1997) realizaram testes para medir a precisão de um sensor de posição. O sistema era composto por um mapa digital que continha todas as coordenadas para descrever o percurso e um sensor para medir a posição atual, calculando o erro de posicionamento. Foi equipado um trator para determinar o erro obtido pelo sensor em movimento. Os testes foram realizados a velocidade de deslocamento de $0,19 \mathrm{~m} / \mathrm{s}$ e os erros obtidos foram de $3,43 \mathrm{~cm}$. Através de testes estacionários, o equipamento mostrou uma consistência dos dados com erros de $8,6 \mathrm{~mm}$.

Outras aplicações de campo com a utilização do DGPS foram desenvolvidas por Balsari e Tamagnobe (1997) e Longo et al. (1997) utilizando um dispositivo eletromecânico para pulverizadores que permite a aplicação precisa de pequenos volumes de produtos químicos em aplicações com velocidade de deslocamento que variam de 4 a 7 $\mathrm{km} / \mathrm{h}$. Como resultado, reduz em $50 \%$ do custo químico e $50 \%$ a quantia aplicada ao meio ambiente.

Buick (1998) em ensaios realizados na Nova Zelândia, comparou técnicas de orientação incluindo marcadores de espuma e dois sistemas guiado por DGPS. Verificou que o marcador de espuma mostrou um desvio médio de $1,61 \mathrm{~m}$, enquanto o sistema guiado por GPS mostrou um desvio médio de $0,57 \mathrm{~m}$.

Testes utilizando DGPS como guia de veículos terrestres foram realizados de acordo com Vetter (1995) para determinar faixas paralelas na aplicação de insumos agrícolas com o uso de barra de luz. A precisão do deslocamento foi determinada utilizando uma câmera de vídeo especial. Os dados foram processados medindo a deriva entre a linha de deslocamento e o alinhamento teórico. Através deste método, a utilização do DGPS apresentou excelentes resultados em aplicações terrestres. Em 50 \% 
do tempo o erro foi menor que $0,38 \mathrm{~m}$ e $90 \%$ do tempo foi menor que $0,89 \mathrm{~m}$. A máxima diferença ou desalinhamento para os $23,0 \mathrm{~km}$ de percurso dos testes, esteve abaixo de $1,88 \mathrm{~m}$.

Um estudo realizado na Colômbia comparou custos de pulverização aérea utilizando o sistema orientado por DGPS versus o custo tradicional do sistema transmitindo sinais com bandeiras na cultura da banana. O sistema orientado com DGPS provou ser a alternativa mais eficiente, tanto economicamente como pelos benefícios ao meio ambiente, evitando, dentre outros os riscos de contaminação dos rios. (Ardila, 1996).

Vetter (1996), utilizando um conjunto de barra de luz para a orientação na aplicação aérea, realizou medições de desvio nas passadas paralelas utilizando uma câmera de vídeo que permitia a medida de precisão no posicionamento. A diferença média entre o eixo desejado de deslocamento e o posicionamento dado pelo DGPS foi de $0,30 \mathrm{~m}$. Em $50 \%$ do percurso essa diferença foi abaixo de $0,43 \mathrm{~m}$ e $90 \%$ do percurso abaixo de $0,94 \mathrm{~m}$. A máxima diferença para os $8,0 \mathrm{~km}$ de percurso dos testes, esteve abaixo de 1,3 m, considerado um excelente resultado para essa aplicação.

Molin (1998b), utilizando uma metodologia para medir a precisão de dois sistemas de orientação para aeronaves agrícolas (bandeiras e DGPS), verificou que o sistema guiado por bandeiras apresentou um erro de 2,9 metros com probabilidade de 50 $\%$ e de $4,4 \mathrm{~m}$ com probabilidade de $90 \%$. Já no sistema guiado por DGPS esse erro foi de $0,5 \mathrm{~m}$ com probabilidade de $50 \%$ e $1,4 \mathrm{~m}$ com probabilidade de $90 \%$. 


\section{MATERIAL E MÉTODOS}

\subsection{Caracterização do ensaio do distribuidor de fertilizantes e corretivos.}

Com o intuito de caracterizar as aplicações de insumos a lanço, a primeira etapa deste trabalho visou caracterizar as curvas de deposição transversal, de um distribuidor de arrasto, de mercado, para quatro produtos: calcário, uréia, aveia e adubo granular.

Os ensaios foram realizados no Departamento de Engenharia Rural da ESALQ/USP, com a finalidade de avaliar o desempenho da distribuição de insumos a lanço, segundo a norma ISO 5690/1.

Foi utilizado um distribuidor de arrasto, modelo DCA 5500 RD, fabricado pela Marchesan Implementos e Máquinas Agrícolas "Tatú" S.A., com depósito troncopiramidal de capacidade volumétrica de 2,3 metros cúbicos, com mecanismo dosador volumétrico e distribuidor centrífugo de disco duplo acionado por tomada de potência a 540 rpm, como mostra a Figura 2. 


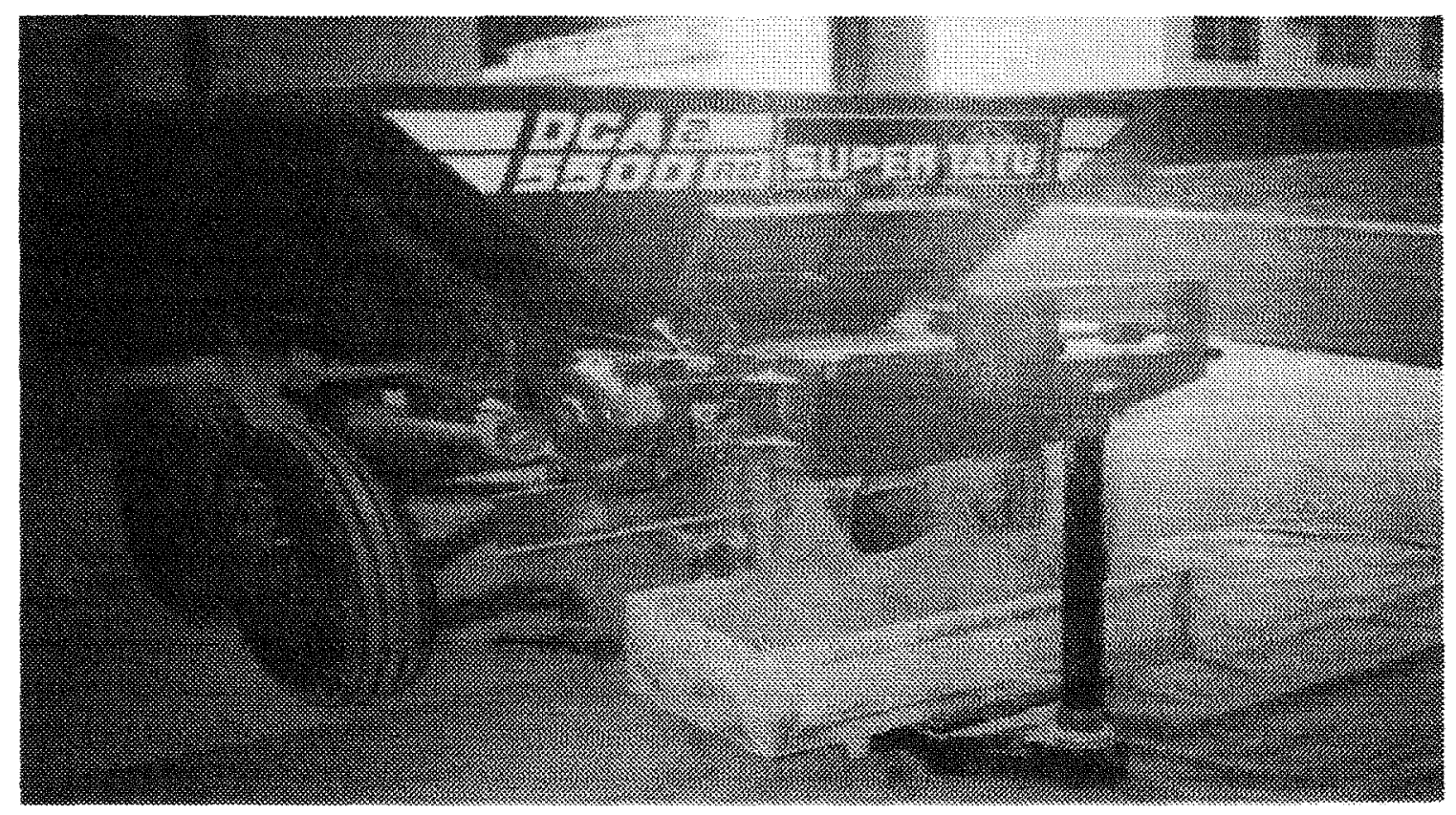

FIGURA 2. Características do equipamento utilizado nos ensaios.

Para seu acionamento foi utilizado um trator Massey Ferguson MF 292. Foram definidas duas velocidades de trabalho: $2,20 \mathrm{~m} \mathrm{~s}^{-1}(8 \mathrm{~km} / \mathrm{h})$ e $3,75 \mathrm{~m} \mathrm{~s}^{-1}(13,5 \mathrm{~km} / \mathrm{h})$. Foram realizados testes para determinação da adequação de marchas do trator a essas velocidades. O procedimento utilizado para a calibração foi cronometrando percurso de 50 metros, para as diferentes marchas, operando a $1900 \mathrm{rpm}$ (540 rpm na TDP).

A máquina foi submetida a uma série de ensaios para caracterização do seu desempenho quanto a distribuição transversal e longitudinal. Para tanto foram utilizados quatro produtos: calcário, adubo granular, uréia e aveia. Inicialmente foi feita a calibração do mecanismo dosador, fazendo variar a posição do regulador de vazão que governa as aberturas do mecanismo. Com o reservatório abastecido a $50 \%$ de sua carga máxima, foi acionado o mecanismo e coletado o material em uma caixa por períodos de 30 segundos. O produto acumulado era então pesado em uma balança com resolução de $0,981 \mathrm{~N}(0,1 \mathrm{kgf})$ e capacidade de $1962 \mathrm{~N}$ (200 kgf). Essa operação foi feita para as 15 posições de abertura do regulador de vazão. Em seguida, a partir dos dados obtidos na coleta e pesagem do produto, determinou-se a curva de calibração da máquina para cada produto testado. 
A Figura 3, determina o posicionamento padrão das aletas dos discos distribuidores para calcário e a Figura 4 determina o posicionamento padrão utilizado para adubos e sementes, conforme especificação do manual do fabricante.

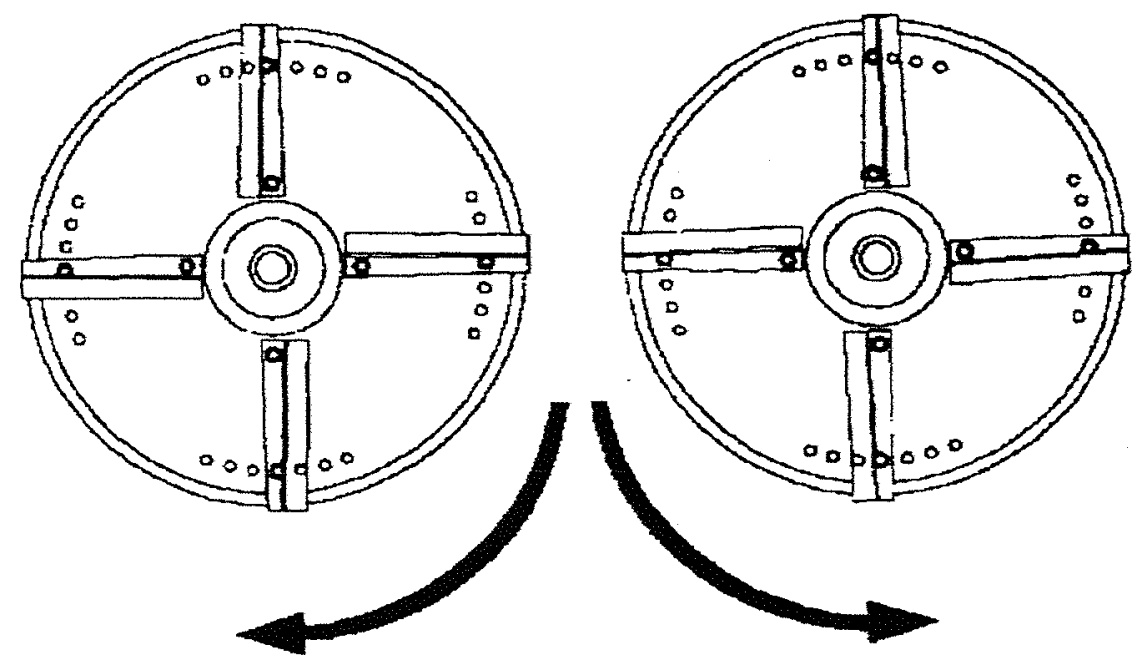

FIGURA 3. Posicionamento padrão das aletas para calcário.
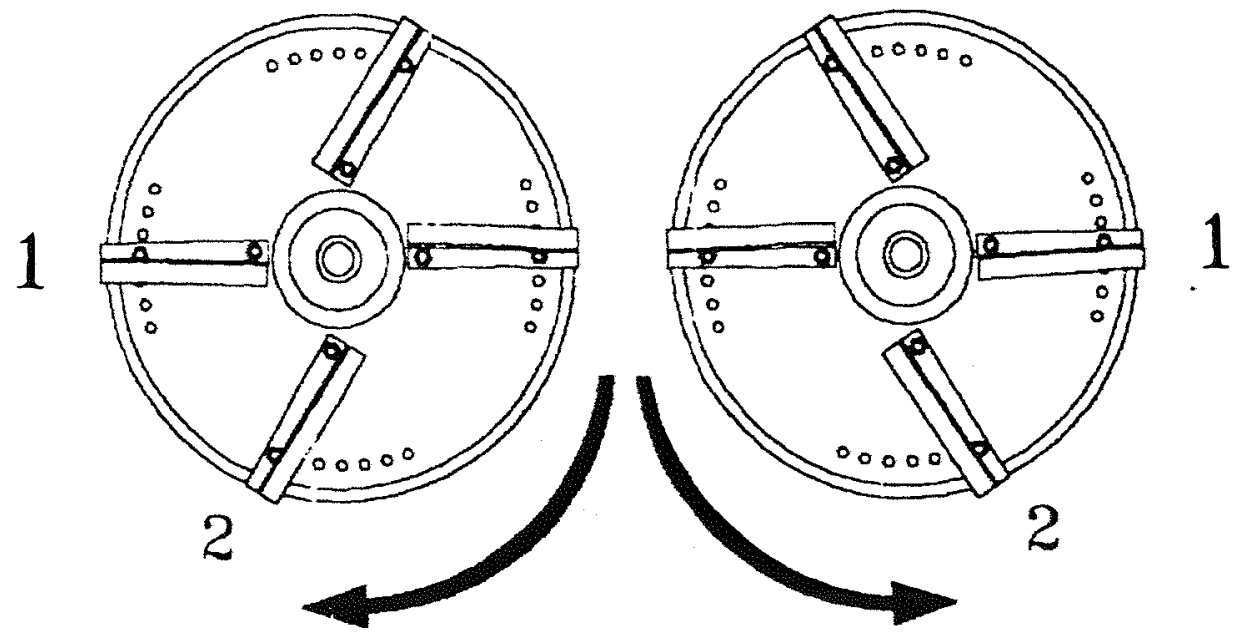

FIGURA 4. Posicionamento padrão das aletas para adubos e sementes. 
Para caracterização dos fertilizantes e corretivos utilizados no ensaio foram feitas determinações de granulometria, conforme norma ISO 5690/1, com amostra de 9,81 N (1 kgf) do produto, retirado do lote antes de passar pelos mecanismos da máquina. Foram utilizadas peneiras com malhas de $0,10 \mathrm{~mm}, 0,50 \mathrm{~mm}, 1,00 \mathrm{~mm}, 2,00 \mathrm{~mm}$ e 4,00 $\mathrm{mm}$, com tempo mínimo de 5 minutos de agitação.

Para a determinação da densidade dos produtos foi utilizado um cilindro com 71 $\mathrm{mm}$ de altura e diâmetro de $65 \mathrm{~mm}$. Após a colocação do produto no recipiente, este foi pesado em uma balança analítica de precisão de $1 \times 10^{-5} \mathrm{kgf}$. A densidade foi obtida através da relação entre a massa e o volume da amostra.

A umidade do produto foi obtida através de amostras colocadas por 24 horas em estufa a temperatura de $105^{\circ} \mathrm{C}$ e determinando a umidade com base seca.

O ângulo de repouso foi determinado através de um dispositivo específico, semelhante ao sugerido por Kurashi et al. (1986) no qual despeja-se o produto que acomoda-se formando uma superficie inclinada e pode-se ler a dimensão dos dois catetos do triângulo formado.

\subsection{Ensaios de caracterização da distribuição transversal e longitudinal.}

Os ensaios foram realizados seguindo-se a norma ISO 5690/1 (1982). Para a coleta do produto aplicado, foram utilizados coletores padronizados, com dimensões de 1000 X $250 \mathrm{~mm}$ X $150 \mathrm{~mm}$ (comprimento, largura e altura), dispostos em superfície horizontal e plana. Os dados foram obtidos pela passagem do distribuidor sobre os coletores dispostos lado a lado. Após 4 passagens do distribuidor sobre os coletores foi recolhido o produto acumulado e colocado em sacos de papel para posterior pesagem em balança analítica de precisão de $1 \times 10^{-5} \mathrm{kgf}$. Foram utilizados plásticos sobre cada coletor para evitar o ricochete da partícula de produto durante a deposição nos ensaios, podendo ser visualizados na Figura 5. 


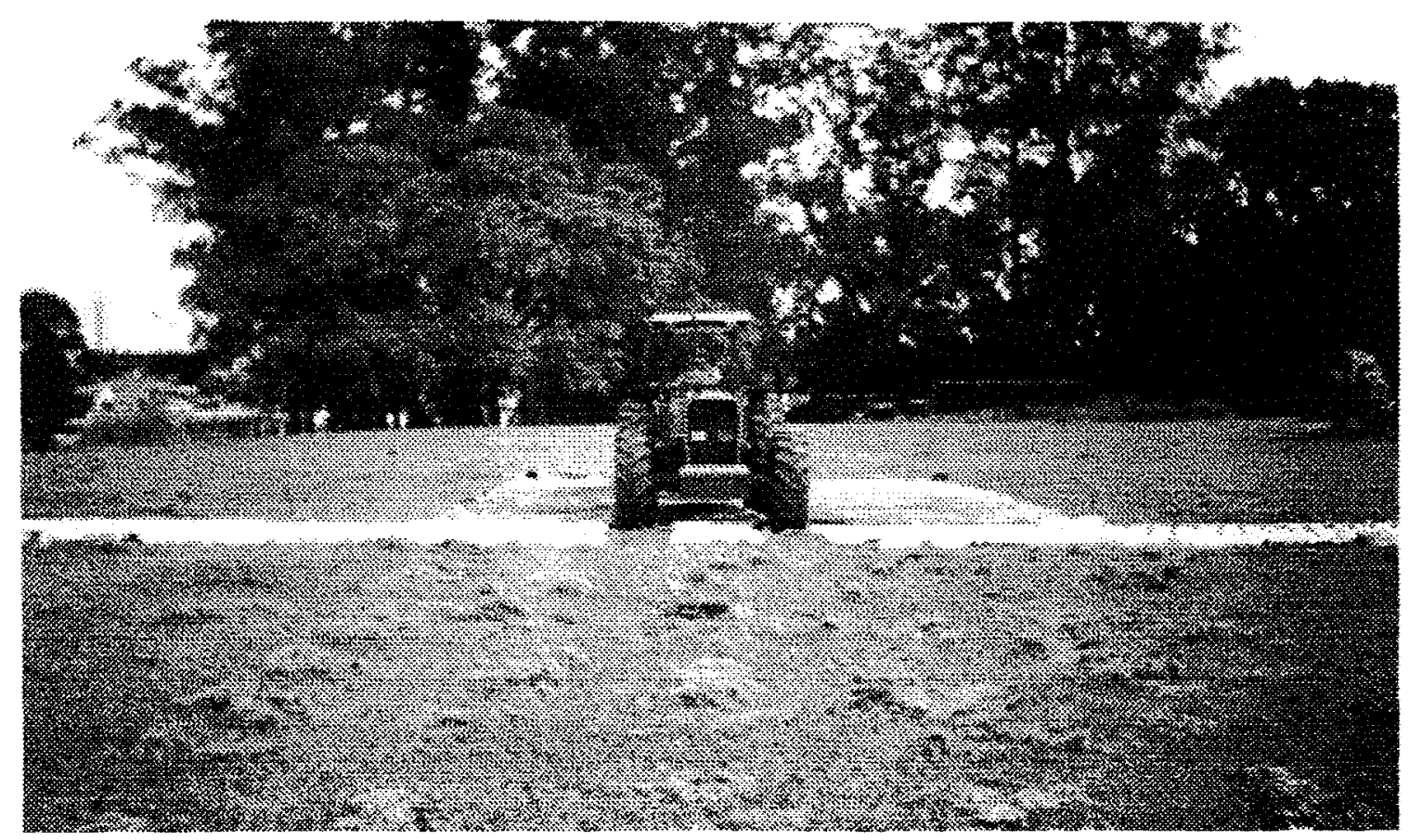

FIGURA 5. Passagem do distribuidor sobre os coletores durante os ensaios.

Por ocasião dos ensaios foi monitorada a velocidade do ar com um anemômetro. Estes foram realizados com velocidade que não ultrapassasse $2 \mathrm{~m} \mathrm{~s}^{-1}$. Através de um psicrômetro foram monitoradas a umidade relativa do ar e a temperatura ambiente. Para verificar o efeito da velocidade de deslocamento nas aplicações, foram utilizadas velocidades de $2,20 \mathrm{~m} \mathrm{~s}^{-1}(8 \mathrm{~km} / \mathrm{h})$ e $3,75 \mathrm{~m} \mathrm{~s}^{-1}(13,5 \mathrm{~km} / \mathrm{h})$.

Para a fixação da vazão utilizada no mecanismo dosador para cada produto durante os ensaios, foi adotada a largura efetiva sugerida pelo fabricante e uma dosagem usual. Para calcário a dosagem estipulada foi de $3.000 \mathrm{kgf} / \mathrm{ha}$, com largura útil de 7,00 metros. Isso resultou numa vazão de 4,55 kgf/s para velocidade de $2,20 \mathrm{~m} \mathrm{~s}^{-1}$ e 8,02 $\mathrm{kgf} / \mathrm{s}$ para a velocidade de $3,75 \mathrm{~m} \mathrm{~s}^{-1}$. O ensaio com calcário foi efetuado com esteira própria (de taliscas). Após o término do ensaio de calcário, realizou-se a troca de esteira utilizando-se outra especifica para baixas dosagens. Para adubo granular a dosagem estipulada foi de $535 \mathrm{kgf} / \mathrm{ha}$, com largura útil de 10,00 metros. Com isso, obteve-se uma vazão de $1,19 \mathrm{kgf} / \mathrm{s}$ para a velocidade de $2,20 \mathrm{~m} \mathrm{~s}^{-1}$ e $2,01 \mathrm{kgf} / \mathrm{s}$ para a velocidade de $3,75 \mathrm{~m} \mathrm{~s}^{-\mathrm{J}}$. 
Para uréia a dosagem foi de $170 \mathrm{kgf} / \mathrm{ha}$, com largura útil de 10,00 metros, conforme especificação do fabricante. A partir disso, resultou numa vazão de $0,37 \mathrm{kgf} / \mathrm{s}$ para a velocidade de $2,20 \mathrm{~m} \mathrm{~s}^{-1}$ e $0,76 \mathrm{kgf} / \mathrm{s}$ para a velocidade de $3,75 \mathrm{~m} \mathrm{~s}^{-1}$.

No caso da aveia, na velocidade de $2,20 \mathrm{~m} \mathrm{~s}^{-1}$, a dosagem estipulada foi de 120 $\mathrm{kgf} / \mathrm{ha}$, com largura útil de 10,00 metros. Com isso, resultou numa vazão de 0,29 kgf/s e $0,44 \mathrm{kgf} / \mathrm{s}$ para a velocidade de $3,75 \mathrm{~m} \mathrm{~s}^{-1}$.

A passagem do distribuidor em funcionamento sobre os coletores foi realizada com quatro passadas sucessivas para posterior coleta do produto acumulado. A partir disto, os dados foram digitados em planilha EXCEL para obtenção dos gráficos de perfil de distribuição transversal. Este mesmo procedimento foi utilizado para obtenção dos gráficos do perfil de distribuição longitudinal, entretanto, para estes ensaios foram utilizados apenas calcário e adubo granular. Com a utilização do programa Adulanço 2.0 foram feitas as análises para determinação do coeficiente de variação como função da largura efetiva. Foram então plotados os resultados de largura efetiva versos coeficiente de variação em cada tratamento para posterior análise e definição da largura efetiva como função de um coeficiente de variação. Este valor pré-estabelecido foi de $15 \%$, considerado aceitável para este tipo de aplicação.

Com a finalidade de determinar as características de distribuição do equipamento ao longo da linha da máquina, 40 coletores foram dispostos longitudinalmente, perfazendo uma distância de 10 metros. Seguindo o mesmo padrão do perfil de distribuição transversal, foram colocados plásticos nos coletores para evitar o ricochete das partículas.

\subsection{Utilização do sistema de GPS.}

A segunda etapa do trabalho visou propor e testar uma metodologia de campo para se determinar a qualidade do alinhamento e paralelismo no deslocamento de um veículo de terra quando guiado por barra de luz governada por DGPS e comparando-o com o deslocamento sem orientação. 
Inicialmente foi realizado um ensaio para verificar a qualidade do equipamento de GPS e do receptor de sinal diferencial. Foram monitorados os valores de PDOP (diluição da precisão), buscando valores menores que 2. Com as antenas (GPS e receptor de sinal diferencial) instaladas sobre o ponto de coordenadas desconhecidas a aferição do equipamento foi realizada em 4 repetições e através destas obteve-se uma média das leituras de latitude e longitude. Para cada repetição foram efetuadas 180 leituras que, para análise, foram segmentadas em sequências de 30 leituras. Cada leitura foi obtida a intervalos de 1,5 segundos, com 270 segundos de coleta de dados para cada repetição.

Para a demarcação dos percursos utilizou-se uma barra porta ferramentas suportando um disco de corte liso que fazia a marcação no solo. Em percursos de 200 metros o operador se localizava através de uma linha base com estacas a cada 50 metros. Após a passagem pela linha base, o operador realizava três novas passadas com espaçamento de 5 metros, simulando uma aplicação.

Nos ensaios foi utilizada uma barra de luz instalada sobre o trator. O conjunto de marca AirStar utilizado é destinado a aplicação em faixas paralelas aéreas. É fornecido pela empresa SatLoc e é composto por uma fonte de potência (1), CPU com drive PCMCIA (2), GPS (3), teclado (4), visor (5), barra de luz (6) e conectado a um receptor OmniStar para alimentação de sinal diferencial (DGPS) via satélite. O equipamento utilizado para realização destes ensaios são apresentados na Figura 6. 
(2)
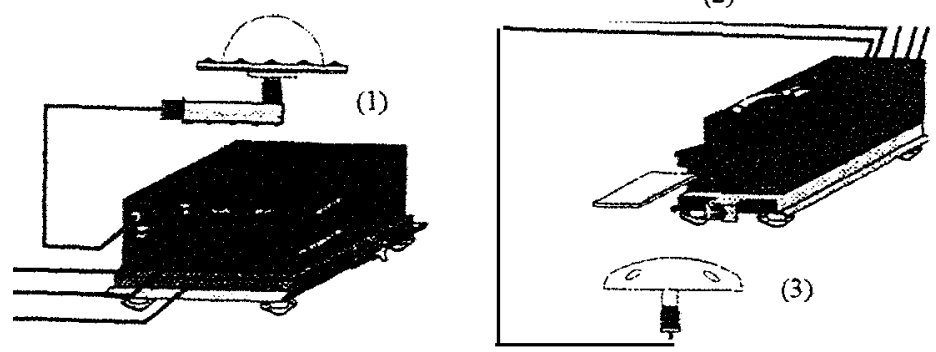

(4)

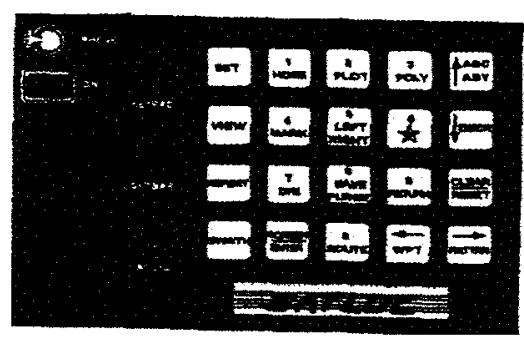

(6)

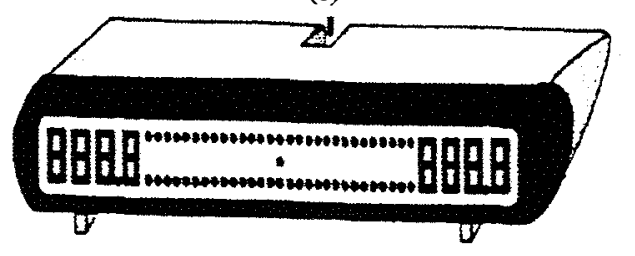

RGT BK-BT WATT - GPS

- I- R $000010 F 0403.5$

GNI 5000/TRK 235

$>B 0000$ - ISPEED 085

$5,5 \equiv=7$

FIGURA 6. Componentes utilizados nas aplicações em faixas paralelas de marca AirStar SatLoc.

(1) - fonte de potência; (2) - CPU com drive PCMCIA; (3) - antena de GPS; (4) - teclado; (5) - visor e (6) barra de luz.

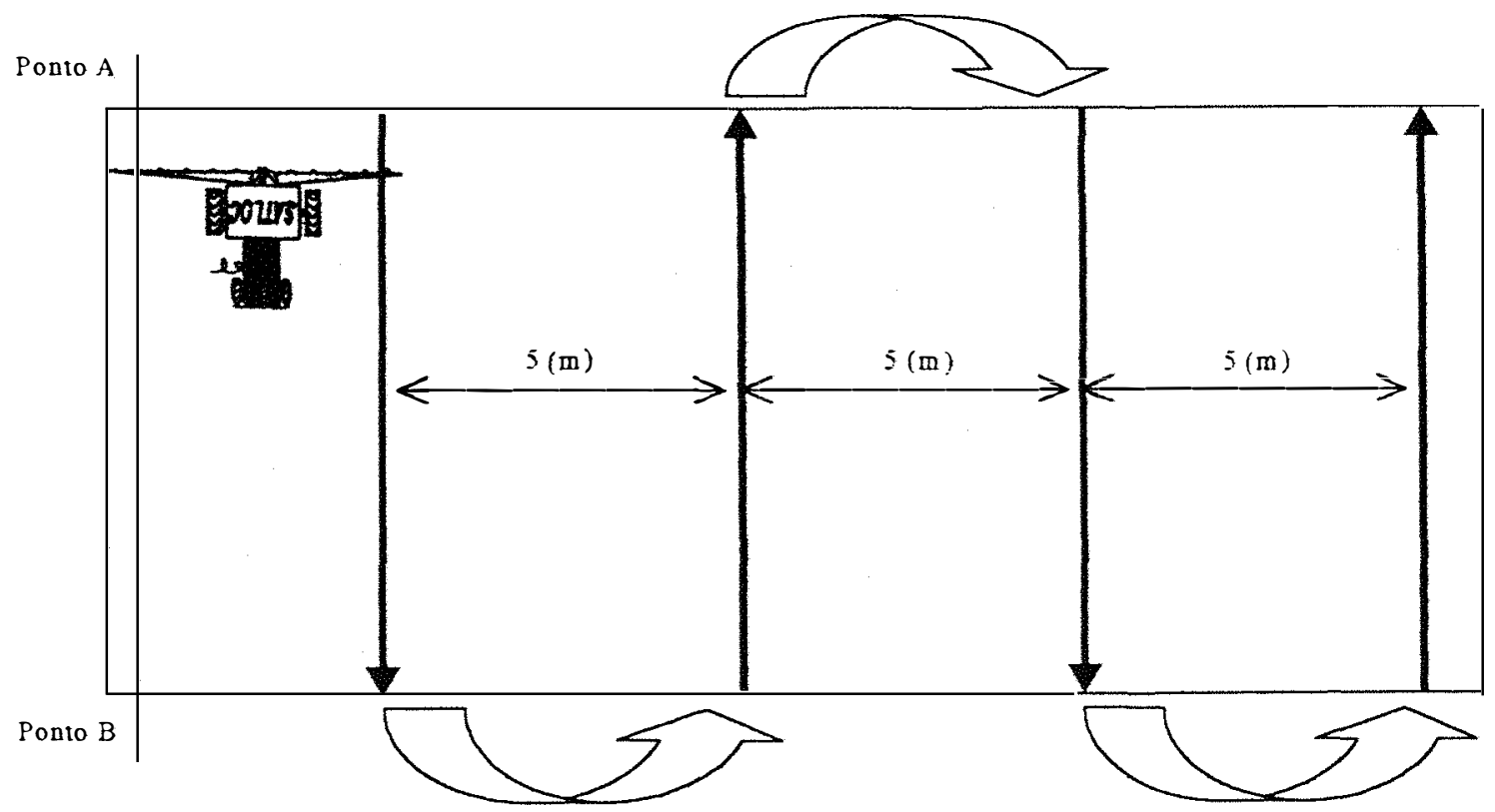

FIGURA 7. Simulação das aplicações em faixas paralelas. 
A barra de luz, posicionada na frente do operador, é uma ferramenta que tem como objetivo orienta-lo a se guiar por uma linha reta. Essa barra de luz é um conjunto de pequenas lâmpadas (led) que acendem a medida que a máquina se afasta do alinhamento pré determinado. A mesma contém 2 mostradores digitais, com duas fileiras de leds disposta horizontalmente, contendo 28 leds cada e uma fileira vertical no centro contendo 3 leds.

A fileira superior de leds indica a distância da linha central em pés ou metros. Os leds vermelhos indicam o erro de posicionamento a esquerda e os verdes indicam o erro de posicionamento para a direita. Os leds amarelos, dispostos verticalmente, indicam um posicionamento correto da linha central. Possui ainda, dois mostradores digitais nas extremidades, um indicando a direção do erro (direito ou esquerdo) e outro indicando o número da passada.

O alinhamento é gerado pelo operador na primeira passada e as demais serão sempre paralelas à primeira com distância equivalente à largura de uma faixa de aplicação, nesse caso, de 5 metros.

O operador deslocava-se com o trator, seguindo a informação dos sinais luminosos da barra de luz. A medida que desviava para a esquerda, acendiam luzes vermelhas a esquerda da barra, indicando a necessidade de correção para a direita para manter o alinhamento. A medida que desviava para a direita, acendiam luzes verdes a direita da barra, indicando a necessidade de correção da posição do trator para a esquerda.

O equipamento foi programado de forma que a barra de luz acendesse um led a cada deslocamento pré determinado da linha central, conforme apresentado na Tabela 1.

TABELA 1. Configuração da barra de luz para os ensaios.

\begin{tabular}{llllllllllllllll}
\hline Números de leds & 1 & 2 & 3 & 4 & 5 & 6 & 7 & 8 & 9 & 10 & 11 & 12 & 13 & 14 & 15 \\
\hline Deslocamento (m) & 0,3 & 0,6 & 0,9 & 1,2 & 1,5 & 2 & 2,5 & 3 & 4 & 5 & 6 & 8 & 10 & 12 & 15 \\
\hline
\end{tabular}

Após a passagem do conjunto marcando o solo utilizou-se um teodolito para fazer a marcação da reta de 200 metros, por onde o mesmo deveria ter passado. Com 
uma trena de 50 metros esticada ao solo, fez-se marcações a cada 10 metros com uma baliza. Nestas marcações, obteve-se o desvio ocorrido através da diferença entre a linha imaginária e a leitura real, num total de 20 pontos ao longo de cada alinhamento.

As informações assim obtidas foram analisadas e sintetizadas na forma de gráficos de frequência e probabilidade de erro.

Os tratamentos consistiram na combinação de duas velocidades $\left(2,20 \mathrm{~m} \mathrm{~s}^{-1} \mathrm{e}\right.$ $3,75 \mathrm{~m} \mathrm{~s}^{-1}$ ) utilizando-se a orientação guiada por DGPS e o método convencional, sem qualquer referência.

Procurando eliminar interferências pessoais os ensaios foram realizados com 5 operadores, com diferentes graus de escolaridade e de experiênçia com operação de máquinas e implementos. O perfil básico dos diferentes operadores é apresentado na Tabela 2.

TABELA 2. Caracterização básica dos operadores envolvidos nos ensaios.

\begin{tabular}{cccc}
\hline Operador & Idade & Anos de experiência como operador & Atividade ocupacional \\
\hline 1 & 26 & 1 & Estudante \\
2 & 33 & 20 & Operador de Máquinas \\
3 & 43 & 21 & Operador de Máquinas \\
4 & 49 & 25 & Operador de Máquinas \\
5 & 45 & 18 & Operador de Máquinas \\
\hline
\end{tabular}

O delineamento experimental utilizado foi de blocos casualizados, utilizando um fatorial $2 \times 2$, em cinco blocos e quatro tratamentos, totalizando 20 parcelas. As médias foram comparadas pelo teste de Tukey ao nivel de $1 \%$ de probabilidade (Pimentel, 1987). 
TABELA 3. Quadro de análise de variância dos ensaios de qualidade dos percursos.

\begin{tabular}{cc}
\hline Causas de variação & G.L. \\
\hline Blocos (Operadores) & 4 \\
Velocidade $\left(2,2 \mathrm{~m} \mathrm{~s}^{-1}\right.$ e $\left.3,75 \mathrm{~m} \mathrm{~s}^{-1}\right)$ & 1 \\
Equipamento (com e sem DGPS) & 1 \\
Velocidade X Equipamento & 1 \\
Resíduo & 12 \\
\hline Total & 19 \\
\hline
\end{tabular}

\subsection{Integração da análise de erro de percurso ao desempenho da máquina.}

O objetivo maior do trabalho foi de permitir a quantificação da qualidade de deposição dos diferentes produtos com base nas curvas de deposição e do erro no deslocamento utilizando ou não o DGPS.

A partir das curvas de coeficiente de variação versus a largura efetiva, fixou-se a largura útil de trabalho dos diversos produtos utilizados nos ensaios. Após estabelecida a largura de trabalho adicionou-se o erro de deslocamento quantificando-se sua influência no coeficiente de variação. Com isso, pôde-se determinar a qualidade do serviço em campo como consequência da largura efetiva acrescida do erro de deslocamento, verificando assim, qual a alteração no coeficiente de variação. 


\section{RESULTADOS E DISCUSSĀO}

\subsection{Curvas de calibração da vazão do mecanismo dosador.}

Através das diversas regulagens de abertura do mecanismo dosador obteve-se as curvas de vazão para os quatro produtos utilizados nos ensaios, conforme mostra a Figura 8.

Com base nessa curva, pode-se determinar o fluxo de material a ser aplicado no solo, através da adequação do posicionamento do regulador de vazão.

As curvas de calibração da vazão do mecanismo dosador apresentaram boa regularidade de vazão com uma tendência linear em função do posicionamento do regulador de vazão para os quatro produtos ensaiados. A partir disto, pode-se determinar o ponto de regulagem de acordo com a largura especificada pelo fabricante para cada produto em função das velocidades pré estabelecidas. Para calcário esta regulagem fícou entre os pontos 5 e 11. Com adubo, a largura de trabalho especificada pelo fabricante resultou no posicionamento de regulagem entre 3 e 9 . Já com uréia, a largura de trabalho estabelecida resultou na regulagem de posicionamento entre os pontos 1 e 2 . No caso da aveia, a variação da posição do regulador de vazão, ficou entre os pontos 3 e 5. 
VAZĀo - CALCÁRIO

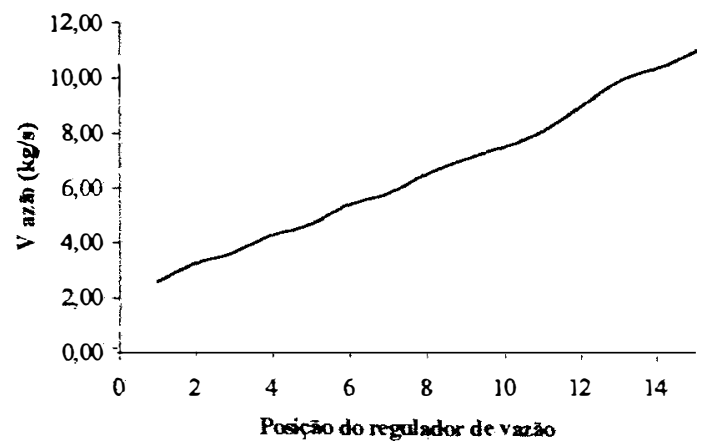

VAZĀO - URÉIA

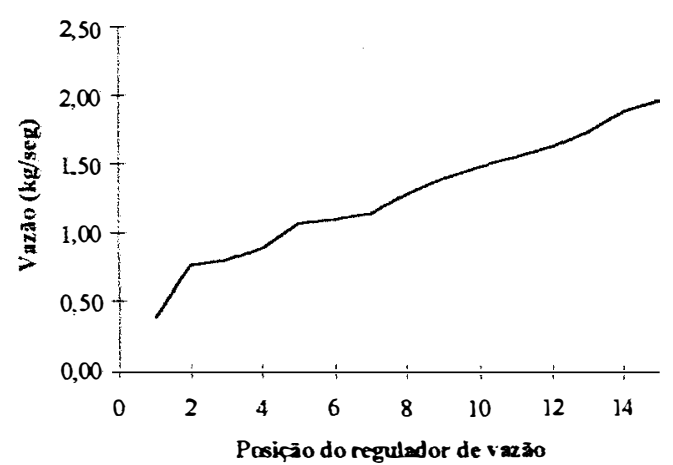

VAZĀO - ADUBO GRANULAR

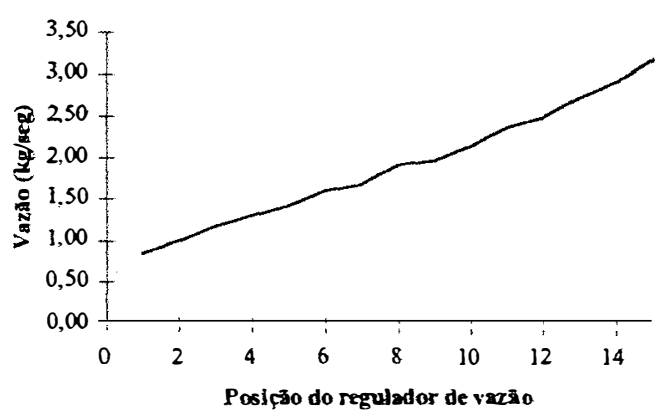

VAZÃO - AVEIA

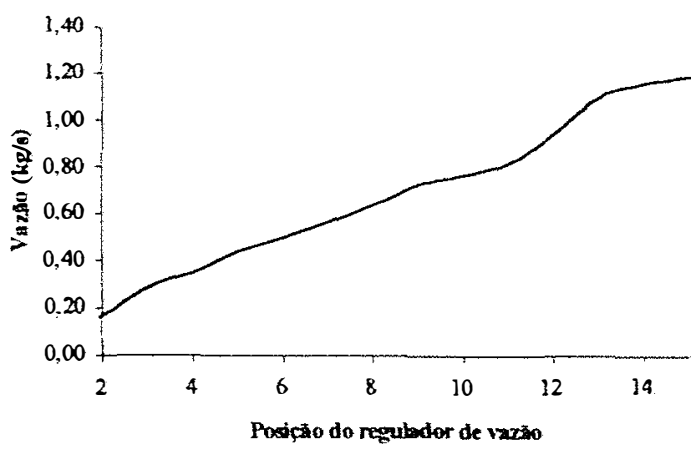

FIGURA 8. Curvas de calibração da vazão do mecanismo dosador para os quatro produtos utilizados nos ensaios.

\subsection{Caracterização dos fertilizantes e corretivos utilizados.}

A análise das características físicas dos insumos obtidas em laboratório constituiu na determinação da granulometria, densidade, umidade e ângulo de repouso.

A Tabela 4, mostra a caracterização dos fertilizantes e corretivos utilizados. Os resultados obtidos das amostras dos diferentes produtos apresentam grandes variações granulométricas. Observa-se de uma maneira geral, que o comportamento de deposição das partículas tendem a concentrar-se ao centro da aplicação com partículas finas. Do mesmo modo, as partículas grosseiras tendem a concentrar-se nas extremidades da largura de aplicação. Entretanto, tal fato não exerceu influência sobre o trabalho da 
máquina: Além disso, os produtos ensaiados apresentaram boa porcentagem de umidade além de boas características de escoamento.

TABELA 4. Características físicas obtidas em laboratório para os fertilizantes, corretivo e aveia utilizados nos ensaios.

\begin{tabular}{|c|c|c|c|c|c|}
\hline \multirow[b]{3}{*}{ Parâmetro } & \multirow[b]{3}{*}{ n. ${ }^{\circ}$ malha } & \multicolumn{4}{|c|}{ Produto } \\
\hline & & Calcário & Adubo & Uréia & Aveia \\
\hline & & \multicolumn{4}{|c|}{ retido na peneira } \\
\hline \multirow{8}{*}{ Granulometria } & $\mathrm{mm}$ & . & -------- & - & -1.-. \\
\hline & 0,0 & 28,78 & 3,10 & 0,00 & 13,28 \\
\hline & 0,1 & 44,76 & 10,25 & 12,80 & -....- \\
\hline & 0,5 & 18,25 & 2,66 & 6,38 & $\ldots$ \\
\hline & 1,0 & 7,05 & 19,33 & 32,13 & -.---- \\
\hline & 2,0 & 0,96 & 64,42 & 47,96 & ....... \\
\hline & 4,0 & 0,00 & 0,24 & 0,73 & 25,94 \\
\hline & 4,5 & -..-- & -...-. & -...... & 60,78 \\
\hline Densidade $\left(\mathrm{g} / \mathrm{cm}^{3}\right)$ & $\ldots$ & 1,89 & 1,37 & 0,89 & 0,64 \\
\hline Umidade (\%) & $\cdots$ & 6,4 & 3,48 & 1,51 & 9,4 \\
\hline Ângulo de repouso $\left({ }^{\circ}\right)$ & -....... & 34 & 29 & 33 & 28 \\
\hline
\end{tabular}

\subsection{Perfil de distribuição transversal.}

Os ensaios foram conduzidos entre 10/02/1998 e 24/03/1998. No ensaio realizado para calcário a temperatura ambiente ficou em tomo de $24{ }^{\circ} \mathrm{C}$, com umidade relativa do ar a $70 \%$ e velocidade do vento variando de 0,1 a $1,2 \mathrm{~m} \mathrm{~s}^{-1}$. O ensaio realizado com adubo granular a temperatura estava em torno de $33{ }^{\circ} \mathrm{C}$, com umidade relativa do ar a $56 \%$ e velocidade do vento variando de 0,1 a $0,8 \mathrm{~m} \mathrm{~s}^{-1}$. Para uréia, a temperatura ficou por volta de $34^{\circ} \mathrm{C}$, com umidade relativa do ar a $69 \%$ e velocidade do 
vento variando de 0,0 a $0,1 \mathrm{~m} \mathrm{~s}^{-1}$. Já no ensaio de aveia, a temperatura média fícou em tomo dos $30^{\circ} \mathrm{C}$ com umidade relativa do ar a $56 \%$ e velocidade do vento variando de 0,0 a $0,8 \mathrm{~m} \mathrm{~s}^{-1}$.

A partir dos dados obtidos após pesagem do material coletado, observam-se na Figura 9, os diferentes perfis de distribuição transversal para os diversos tratamentos. 


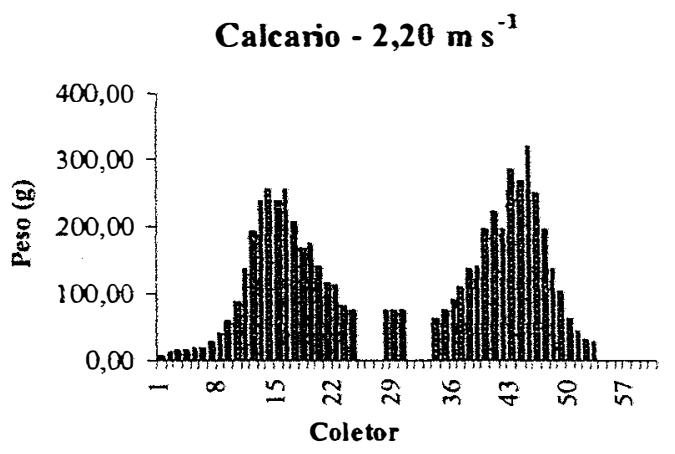

Adubo granular $-2,20 \mathrm{~m} \mathrm{~s}^{-1}$
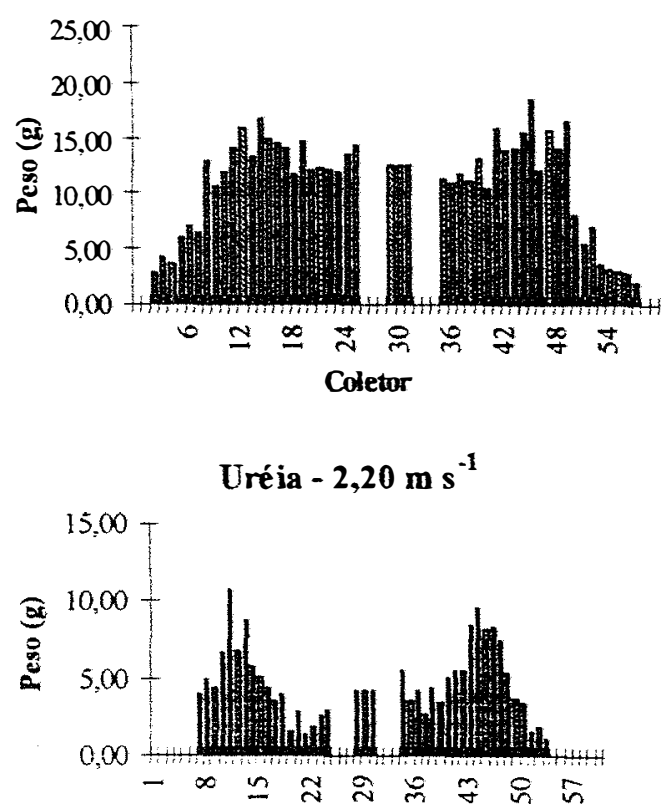

Coletor

Aveia $-2,20 \mathrm{~m} \mathrm{~s}^{-1}$

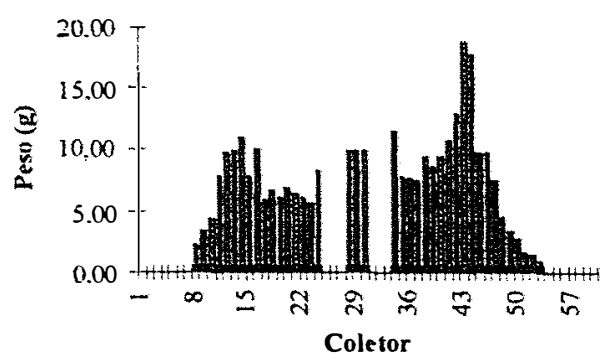

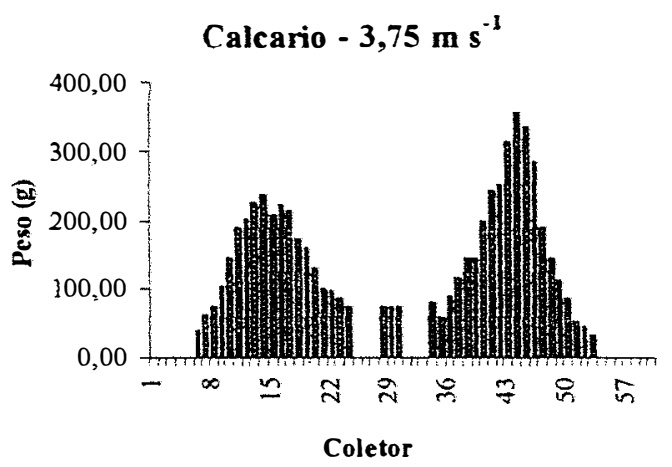

Adubo granular $-3,75 \mathrm{~m} \mathrm{~s}^{-1}$

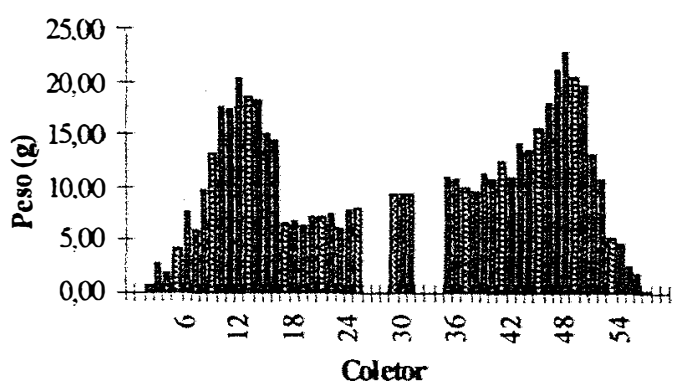

Uréia $-3,75 \mathrm{~m} \mathrm{~s}^{-1}$

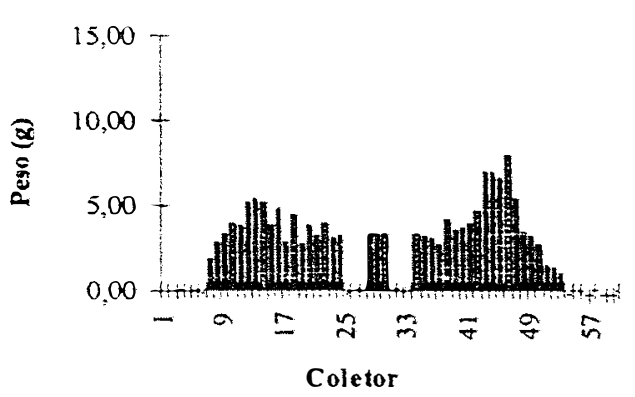

Aveia $-3,75 \mathrm{~m} \mathrm{~s}^{-1}$

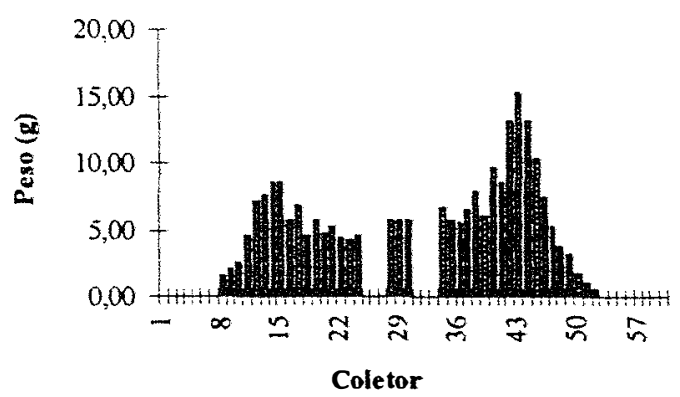

FIGURA 9. Perfil de distribuição transversal dos diferentes tratamentos: distribuição de calcário, adubo, uréia e aveia nas velocidades de $2,20 \mathrm{~m} \mathrm{~s}^{-1}$ e $3,75 \mathrm{~m} \mathrm{~s}^{-1}$. 
Analisando os gráficos do perfil de distribuição transversal do calcário e da aveia observa-se que a velocidade de deslocamento não teve grande influência no perfil. Para calcário a quantidade de deposição basicamente se equivaleu, apresentando o mesmo formato nas duas velocidades. Entretanto para aveia a quantidade de deposição resultou em maior acúmulo de material na velocidade de $2,20 \mathrm{~m} \mathrm{~s}^{-1}$. Para o perfil de distribuição do adubo granular e da uréia, observa-se maior variação entre as duas velocidades ensaiadas.

Os resultados de perfil de distribuição transversal foram analisados utilizando-se o programa ADULANÇO 2.0 para a obtenção das relações entre coeficiente de variação e largura efetiva dos diversos tratamentos. Esses resultados podem ser visualizados na Figura 10, onde é apresentada a largura de trabalho como função do coeficiente de variação em percurso: perimétrico e altemado. 

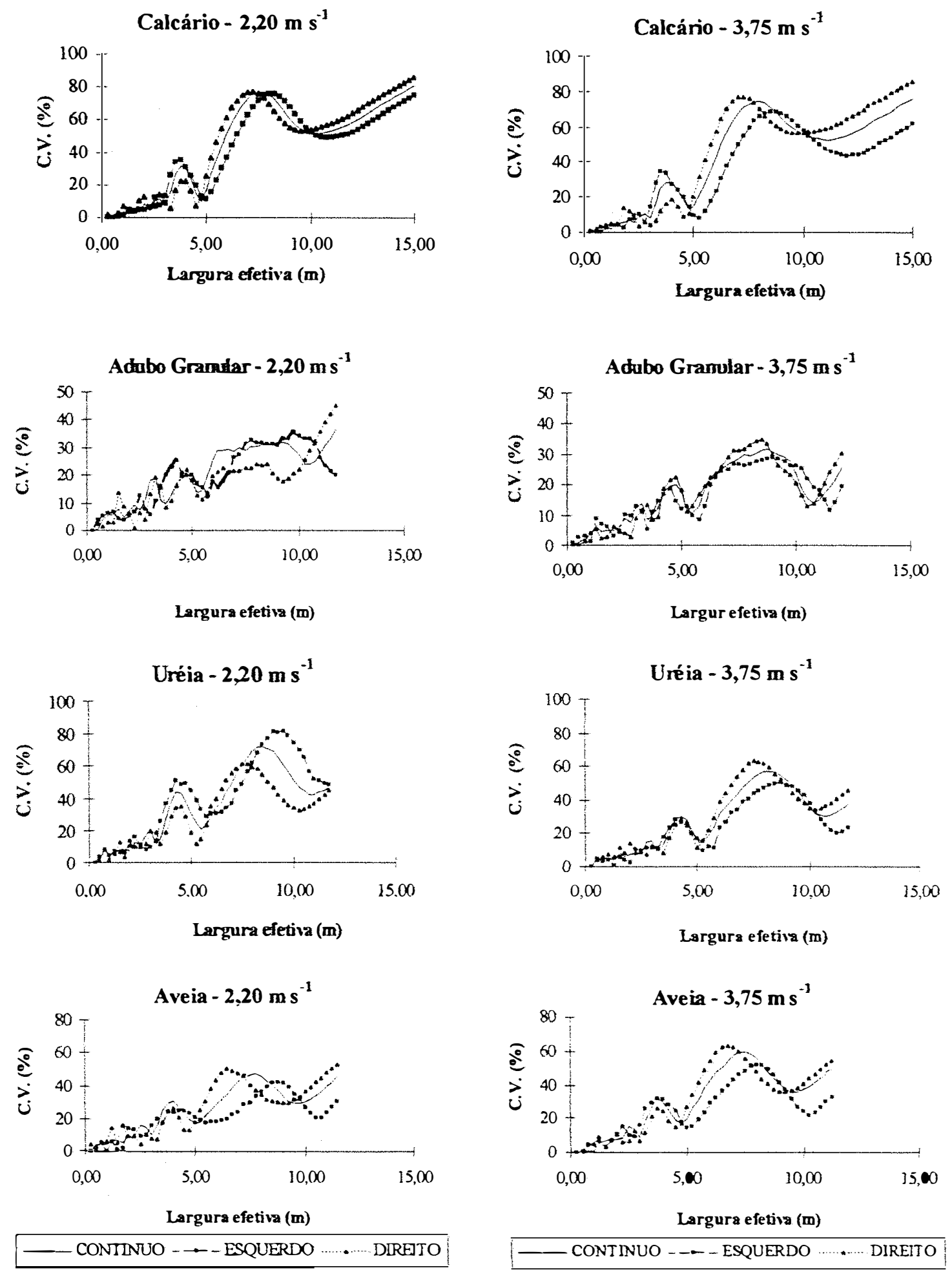

FIGURA 10. Resultados simulados do coeficiente de variação como função da largura efetiva para os diferentes métodos de percurso possíveis para cada tratamento. 
Para efeito da análise da largura efetiva, atribuíram-se valores de coeficiente de variação de referência de $12,5,15,0$ e 20,0 \% com base em estudos realizados por outros autores como Dallmeyer (1985) e Fontana et al. (1985). Os coeficiente de variação fixados para a determinação da largura efetiva de trabalho são considerados valores normais para ensaios agricolas de campo, conforme Campos (1984). Os resultados são apresentados na Tabela 5.

TABELA 5. Largura efetiva de trabalho em função dos valores fixados para o coeficiente de variação de $12,5 \% ; 15,0 \%$ e $20,0 \%$.

\begin{tabular}{cccccccc}
\hline \multicolumn{7}{c}{ Largura efetiva (m) } \\
Velocidades $\left(\mathrm{m} \mathrm{s}^{-1}\right)$ & \multicolumn{5}{c}{ Percurso } \\
\hline \multirow{2}{*}{ Produtos } & C.V. (\%) & Continuo & Esquerdo & Direito & Continuo & Esquerdo & Direito \\
\hline \multirow{2}{*}{ Calcário } & 12,50 & 5,00 & 5,00 & 4,80 & 3,00 & 5,60 & 5,00 \\
& 15,00 & 5,00 & 5,00 & 5,00 & 5,00 & 5,60 & 5,00 \\
& 20,00 & 5,00 & 5,00 & 5,20 & 5,00 & 5,80 & 5,00 \\
\hline \multirow{3}{*}{ Adubo } & 12,50 & 4,00 & 5,50 & 6,00 & 5,80 & 11,50 & 10,50 \\
& 15,00 & 4,00 & 6,30 & 6,00 & 11,00 & 11,80 & 11,00 \\
& 20,00 & 5,60 & 6,50 & 9,50 & 11,60 & 12,00 & 11,30 \\
\hline \multirow{2}{*}{ Uréia } & 12,50 & 2,30 & 3,30 & 5,30 & 3,50 & 5,80 & 5,00 \\
& 15,00 & 3,50 & 3,30 & 5,50 & 5,00 & 6,00 & 5,30 \\
& 20,00 & 3,60 & 3,80 & 5,60 & 5,50 & 6,00 & 5,50 \\
\hline \multirow{2}{*}{ Aveia } & 12,50 & 3,00 & 3,50 & 4,80 & 3,00 & 5,00 & 3,30 \\
& 15,00 & 3,30 & 3,80 & 5,00 & 3,00 & 5,00 & 5,00 \\
& 20,00 & 5,00 & 10,50 & 5,00 & 5,00 & 5,50 & 5,00 \\
\hline
\end{tabular}

Analisando-se primeiramente os resultados de largura efetiva obtidos para calcário na velocidade de deslocamento de $2,20 \mathrm{~m} \mathrm{~s}^{-1}$, observa-se pouca variação na largura efetiva em relação aos coeficientes pré fixados. A largura efetiva resultou entre 
4,80 e 5,20 m. Entretanto, observa-se que a utilização da sobreposição do lado direito, apresentou a maior largura de trabalho. Para velocidade de deslocamento de $3,75 \mathrm{~m} \mathrm{~s}^{-1}$, a largura de trabalho variou de 3,00 a $5,80 \mathrm{~m}$.

Os resultados de largura efetiva obtidos para adubo granular a $2,20 \mathrm{~m} \mathrm{~s}^{-1}$, apresentaram grande variação na largura efetiva através dos valores de coeficiente de variação prefixados. Observa-se ainda, que as sobreposições contínuas, com coeficiente de variação menor que $20 \%$, apresentam resultados indesejáveis de largura efetiva. Já para velocidades de $3,75 \mathrm{~m} \mathrm{~s}^{-1}$ ocorreu pouca variação quanto a utilização do coeficiente de variação de 15 a $20 \%$, variando de 11,00 a 12,00 m de largura efetiva.

A uréia, que vem sendo amplamente utilizada nas aplicações a lanço, resultou em grande variação de largura efetiva na velocidade de deslocamento de $2,20 \mathrm{~m} \mathrm{~s}^{-1}$, entre os coeficientes de variação prefixados. A largura máxima de aplicação $(5,60 \mathrm{~m})$ foi obtida com coeficiente de variação de $20 \%$, sendo consideradas inviáveis as aplicações com largura efetiva referente aos coeficientes de variação menores. Para velocidade de 3,75 $\mathrm{m} \mathrm{s}^{-1}$ as aplicações ficaram em tomo de 5,0 a $6,0 \mathrm{~m}$, confrontando com as especificações do fabricante, que para adubos e sementes, indicam uma largura efetiva de trabalho de 10,0 m. Em trabalhos anteriormente desenvolvidos, embora em condições diferentes, Spugnoli et al. (1989) utilizando largura de trabalho de 7,00 m obtiveram valores relativamente altos de coeficiente de variação (entre 42 a $55 \%$ ).

Para aveia, verifica-se grande variação através dos métodos de sobreposições e os coeficiente de variação. $\mathrm{Na}$ velocidade de deslocamento de $2,20 \mathrm{~m} \mathrm{~s}^{-1}$, obteve-se melhor resultado utilizando um coeficiente de variação de $20 \%$ e sobreposição do lado esquerdo, com largura útil de trabalho de $10,50 \mathrm{~m}$. Os valores obtidos com velocidade de $3,75 \mathrm{~m} \mathrm{~s}^{-1}$, resultaram em aumento da largura efetiva com a utilização de coeficiente de variação de $20 \%$. 


\subsection{Perfil de distribuição longitudinal.}

Na Figura 11, são apresentados os perfis longitudinais de distribuição para calcário e adubo granular para as velocidades de deslocamento de $2,20 \mathrm{~m} \mathrm{~s}^{-1}$ e 3,75 $\mathrm{m} \mathrm{s}^{-1}$ e na Tabela 6 são apresentados parâmetros estatísticos relacionados a essas distribuições.
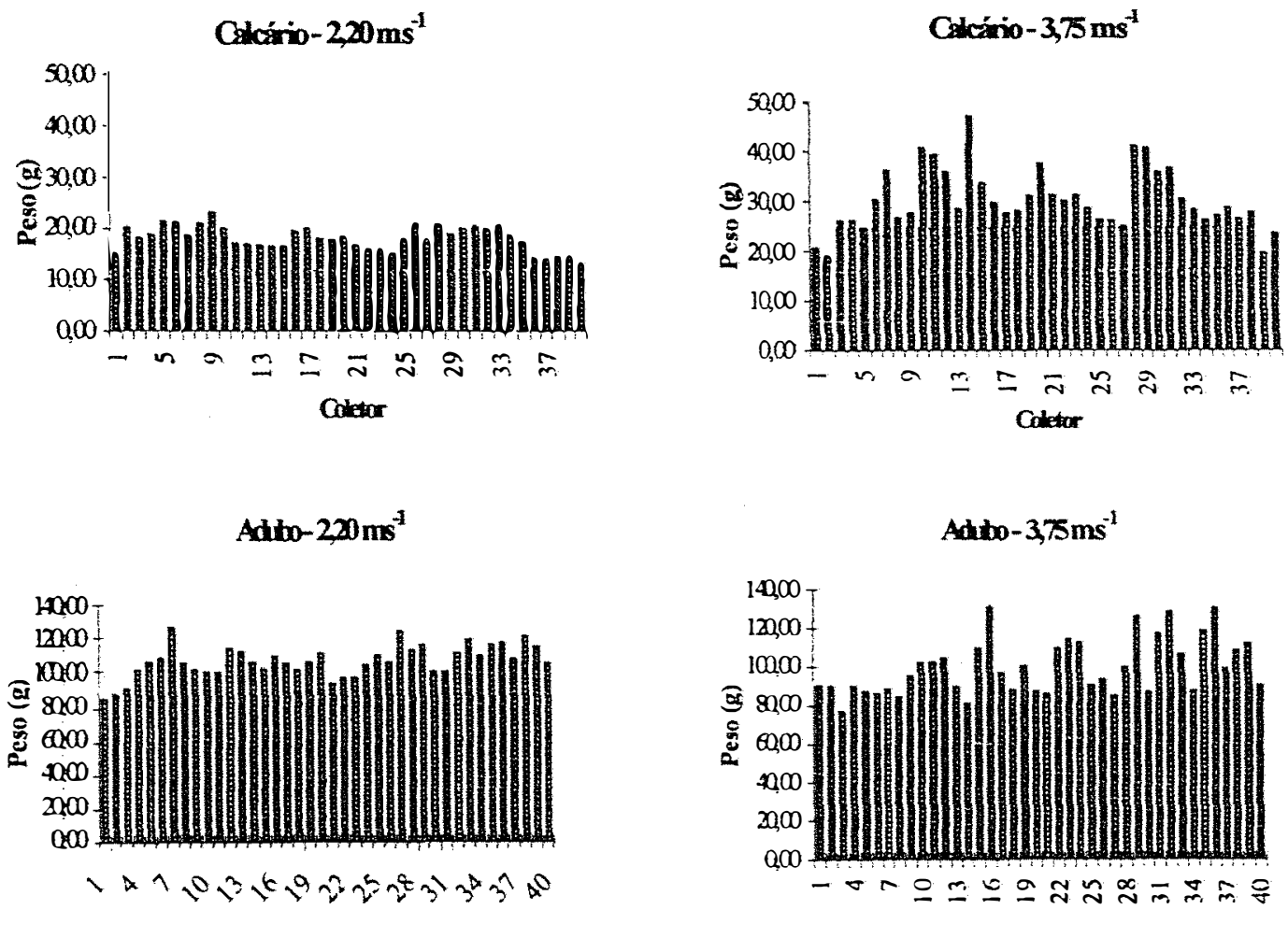

Cletar

Coldor

FIGURA 11. Perfil de distribuição longitudinal de calcário e adubo granular para as duas velocidades testadas.

Analisando os resultados do perfil de distribuição longitudinal de calcário verifica-se aumento na variação do perfil de distribuição com o aumento de velocidade de $2,20 \mathrm{~m} \mathrm{~s}^{-1}$ para $3,75 \mathrm{~m} \mathrm{~s}^{-1}$. Pode-se supor que, com o aumento na velocidade, ocorreram alterações na distribuição que causaram acréscimo no coeficiente de variação de $13,1 \%$ para $21,0 \%$. Já para a distribuição longitudinal de adubos essa variação foi menor, fazendo variar o coeficiente de variação de $8,6 \%$ para $14,4 \%$ com o acréscimo na velocidade de $2,20 \mathrm{~m} \mathrm{~s}^{-1}$ para $3,75 \mathrm{~m} \mathrm{~s}^{-1}$. 
TABELA 6. Valores de média de deposição e coeficiente de variação do perfil de distribuição longitudinal obtidos para os diferentes produtos ensaiados.

\begin{tabular}{ccccc}
\hline Parâmetro & \multicolumn{2}{c}{ Calcário } & \multicolumn{2}{c}{ Adubo } \\
& $2,20 \mathrm{~m} \mathrm{~s}^{-1}$ & $3,75 \mathrm{~m} \mathrm{~s}^{-1}$ & $2,20 \mathrm{~m} \mathrm{~s}^{-1}$ & $3,75 \mathrm{~m} \mathrm{~s}^{-1}$ \\
\hline Média & 17,9 & 30,1 & 108,7 & 99,6 \\
Coeficiente de Variação (\%) & 13,1 & 21,0 & 8,6 & 14,4 \\
\hline
\end{tabular}

\subsection{Análise da qualidade dos percursos de campo.}

Os resultados do ensaio preliminar que visava caracterizar a qualidade do equipamento de DGPS são mostrados resumidamente na Figura 12. Observa-se que a máxima diferença obtida pela posição dada pelo DGPS através das coordenadas $\mathrm{x}$ e y foi de $0,14 \mathrm{~m}$. A partir dos dados apresentados, pode-se comparar a posição das coordenadas médias, verificando a magnitude da variabilidade das leituras. Com isso, verifica-se que o equipamento apresenta uma certa repetibilidade, embora isso não caracterize sua acurácia. 


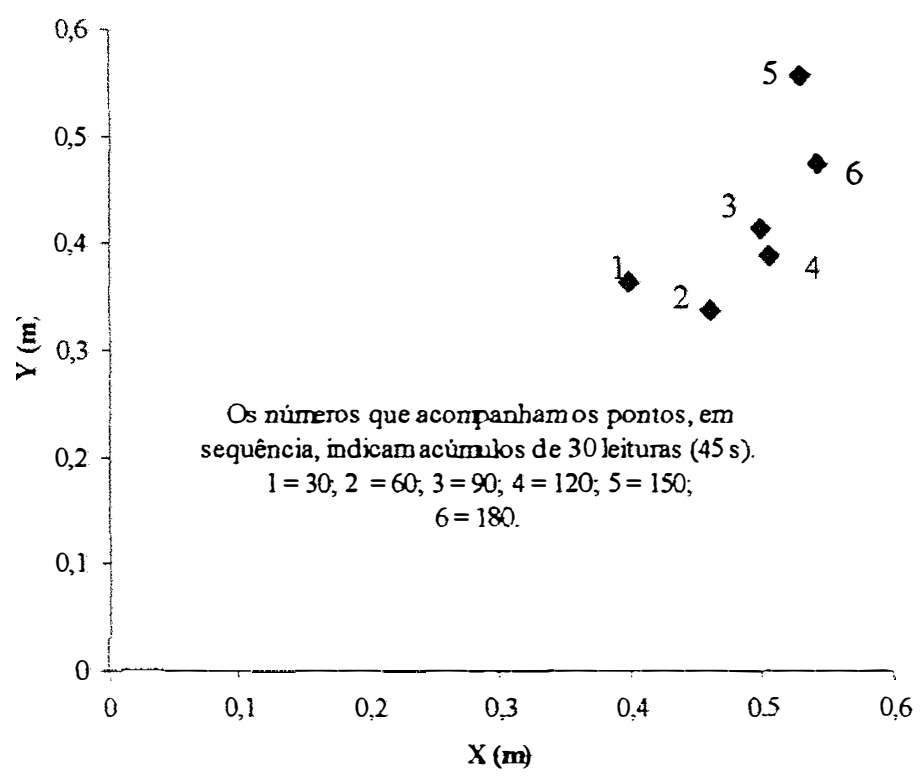

FIGURA 12. Análise da dispersão dos pontos gerados a diferentes tempos de permanência sobre um mesmo local.

O método de marcação dos percursos no campo e medição dos desvios mostrouse eficiente, possibilitando a perfeita visualização da passagem do disco marcador no solo. Dessa forma foi possível determinar com exatidão os desvios ocorridos ao longo dos percursos.

A partir dos resultados da análise da variância apresentados na Tabela 7, pode-se afirmar que o equipamento foi o fator que mais contribuiu em termos relativos. Observase também que a interação velocidade $\mathrm{X}$ equipamento não foi significativa. $\mathrm{A}$ velocidade, por sua vez, mostrou ter influência significativa ao nível de $1 \%$ de probabilidade. Outro fator importante que influenciou nos ensaios foram os blocos representados pelos operadores, contribuindo significativamente para a variabilidade do resultado final. 
TABELA 7 Composição da variância do resultado do ensaio de quantificação do erro de percurso com e sem a utilização da barra de luz governada por DGPS ${ }^{1}$.

\begin{tabular}{cc}
\hline Causas de variação & teste $\mathbf{F}$ \\
\hline Blocos (Operadores) & $6,08^{*}$ \\
Velocidades $\left(2,20 \mathrm{~m} \mathrm{~s}^{-1}\right.$ e $\left.3,75 \mathrm{~m} \mathrm{~s}^{-1}\right)$ & $21,17^{*}$ \\
Equipamento (com e sem DGPS) & $292,30^{*}$ \\
Velocidade X Equipamento & 0,74 \\
\hline - Resultado da análise de variância seguidas de * diferem entre si pelo teste F a 1 \% de probabilidade.
\end{tabular}

Na Tabela 8 são apresentados os erros médios de desvios. O erro médio na velocidade de deslocamento de $2,20 \mathrm{~m} \mathrm{~s}^{-1}$ com a utilização da barra de luz, difere estatisticamente dos demais tratamentos ao nivel de $1 \%$ de probabilidade. Observa-se ainda que as médias de erros obtidas sem a utilização da barra de luz nas duas velocidades ensaiadas, não diferem estatisticamente entre si. Verifica-se que com a utilização da barra de luz, o aumento da velocidade resultou em um menor erro, tendo um desvio médio de $0,91 \mathrm{~m}$ da linha teórica para velocidade de $3,75 \mathrm{~m} \mathrm{~s}^{-1}$ contra $1,42 \mathrm{~m}$ para velocidade de deslocamento de $2,20 \mathrm{~m} \mathrm{~s}^{-1}$. Já para os tratamentos sem a barra de luz, o desvio médio resultante foi de $2,92 \mathrm{~m}$ para a velocidade de $2,20 \mathrm{~m} \mathrm{~s}^{-1}$ e $2,57 \mathrm{~m}$ para a velocidade de $3,75 \mathrm{~m} \mathrm{~s}^{-1}$.

TABELA 8. Média dos erros no deslocamento para as duas velocidades testadas com e sem a barra de luz ativada por DGPS ${ }^{1}$.

\begin{tabular}{cccc}
\hline Velocidade & Barra de luz & Desvio Padrão & Média \\
\hline $\mathbf{m ~ s}^{-\mathbf{1}}$ & & $\mathbf{( m )}$ & $\mathbf{( m )}$ \\
2,20 & Sem & 2,1698 & $2,9195 \mathrm{a}$ \\
3,75 & Sem & 2,0268 & $2,5728 \mathrm{a}$ \\
2,20 & Com & 1,2848 & $1,4159 \mathrm{~b}$ \\
3,75 & Com & 0,7131 & $0,9105 \mathrm{c}$ \\
\hline
\end{tabular}

${ }^{1}$ - Médias seguidas de mesma letra na vertical não diferem entre si (Tukey $1 \%$ ).

A Tabela 9 apresenta os parâmetros estatísticos de frequência de erro com e sem a utilização de DGPS. 
TABELA 9. Estatística descritiva da frequência de erro.

\begin{tabular}{|c|c|c|c|c|}
\hline Parâmetro & $\begin{array}{c}\text { Com DGPS } \\
2,20 \mathrm{~m} \mathrm{~s}^{-1}\end{array}$ & $\begin{array}{c}\text { Com DGPS } \\
3,75 \mathrm{~m} \mathrm{~s}^{-1}\end{array}$ & $\begin{array}{c}\text { Sem DGPS } \\
2,20 \mathrm{~m} \mathrm{~s}^{-1}\end{array}$ & $\begin{array}{c}\text { Sem DGPS } \\
3,75 \mathrm{~m} \mathrm{~s}^{-1}\end{array}$ \\
\hline Média (m) & 1,42 & 0,91 & 2,92 & 2,57 \\
\hline Coeficiente de variação (\%) & 90,14 & 78,02 & 74,32 & 78,99 \\
\hline Desvio padrão (m) & 1,28 & 0,71 & 2,17 & 2,03 \\
\hline Assimetria $\left({ }^{\circ}\right)$ & 1,49 & 1,28 & 0,64 & 0,75 \\
\hline Curtose $\left(^{\circ}\right)$ & 2,68 & 1,62 & $-0,61$ & $-0,38$ \\
\hline
\end{tabular}

Os resultados dos ensaios de campo são reportados como apêndice deste trabalho nas Tabelas de 15 a 17 e figuras de 17 a 21.

A frequência de erro tem como objetivo determinar o desvio promovido com e sem a utilização do DGPS em relação à linha teórica, ao longo do seu percurso. A partir disto, são apresentados nas Figuras 13 e 14 os desvios do trator nas duas velocidades testadas.

A dispersão dos desvios obtidos com a utilização de DGPS teve tendência de erro para à direita do deslocamento. Nos percursos sem a utilização de DGPS observa-se um erro com tendência à esquerda da linba desejada.

Os desvios observados com a utilização de DGPS foram menores que aqueles obtidos sem um método de orientação. No entanto esses desvios podem ser considerados muito elevados e alguns fatores devem ter influenciado a obtenção de tais resultados. Primeiramente deve-se inferir que os operadores não foram treinados. O equipamento foi apresentado e foram feitas algumas demonstrações preliminares para a realização dos ensaios. Desta maneira, os operadores não estavam suficientemente familiarizados com o equipamento. Outro fator pode ter sido a programação da barra de luz que foi configurada para desvios em espaçamentos de $30 \mathrm{~cm}$, nos primeiros 5 leds. Esse valor demonstrou ser muito baixo para a acurácia do sistema.

Mesmo com os desvios maiores que o esperado, os resultados obtidos com a utilização da barra de luz foram melhores do que sem o uso de DGPS. Portanto, a 
utilização de DGPS como guia nas aplicações em faixas paralelas, resulta em maior precisão no alinhamento.

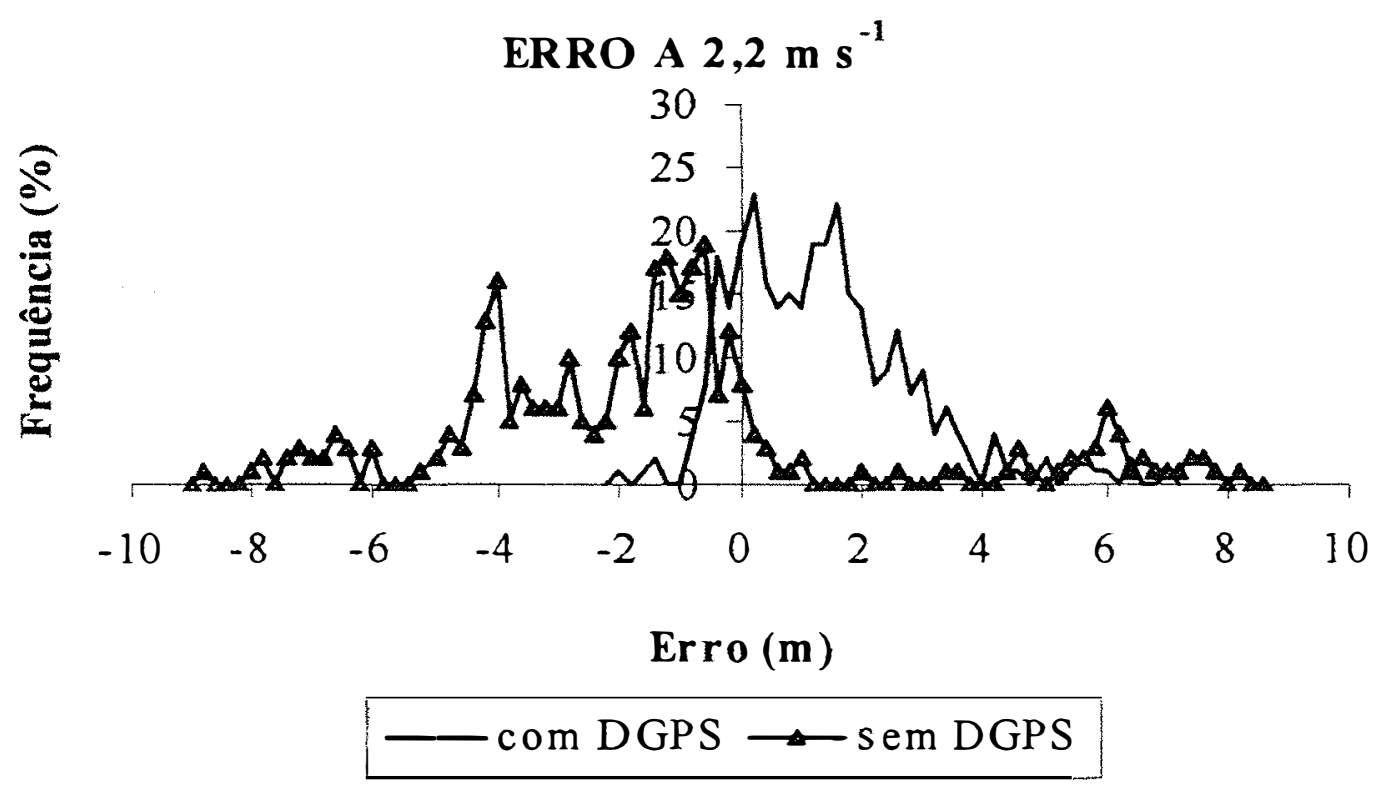

FIGURA 13. Desvio do trator em relação à linha desejada à velocidade de $2,20 \mathrm{~m} \mathrm{~s}^{-1}$.

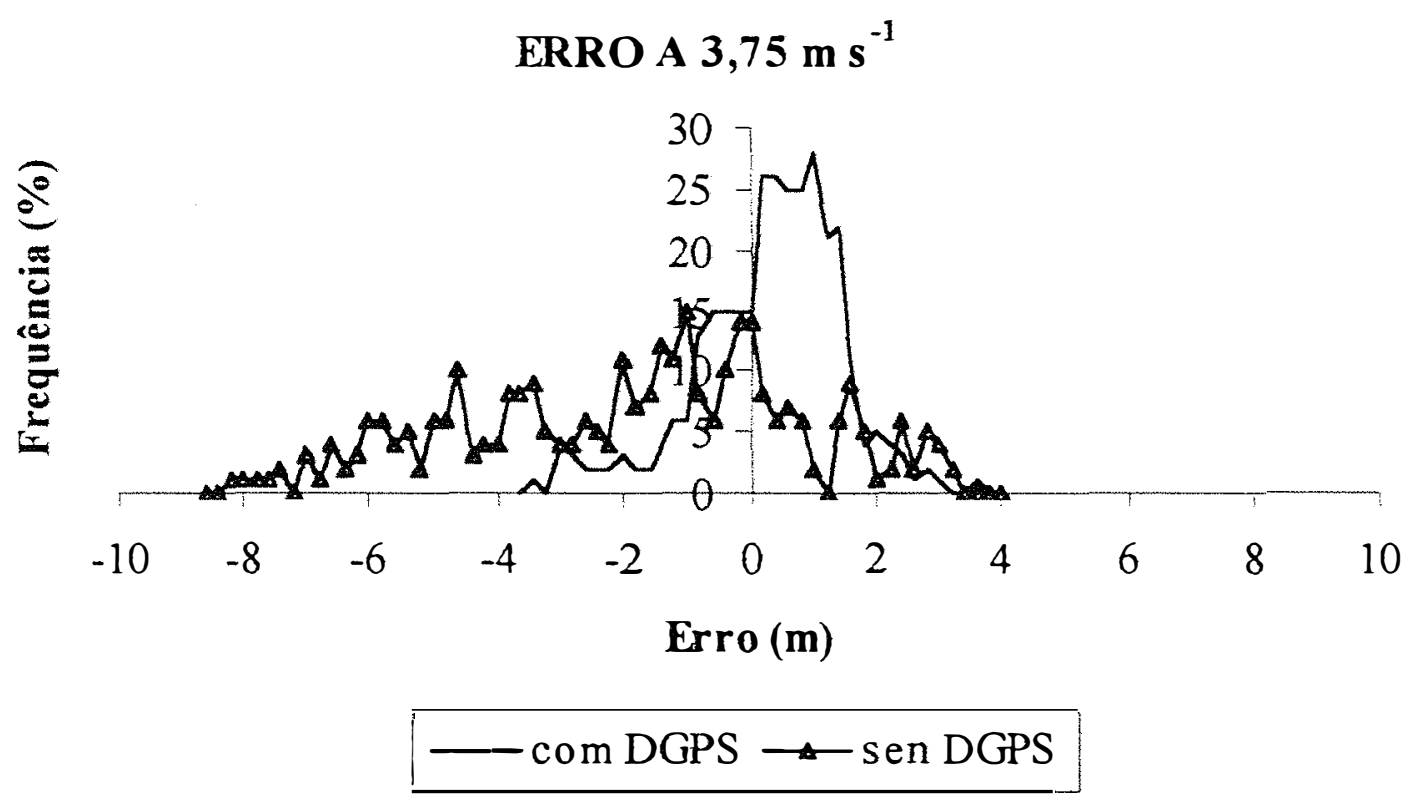

FIGURA 14. Desvio do trator em relação à linha desejada à velocidade de $3,75 \mathrm{~m} \mathrm{~s}^{-1}$. 
As Figuras 15 e 16, mostram as probabilidades de erro para as duas velocidades de deslocamento, com e sem a utilização de DGPS, na orientação de passadas paralelas. Com a utilização do DGPS a velocidade de $2,20 \mathrm{~m} \mathrm{~s}^{-1}$, verifica-se que em $50 \%$ do percurso, o erro obtido foi inferior a $1,65 \mathrm{~m}$ e em $90 \%$ do percurso esse erro manteve-se inferior a 2,50 $\mathrm{m}$ da linha teórica. O ensaio feito sem a utilização do DGPS, mostra que em $50 \%$ do percurso o erro obtido foi inferior a $3,25 \mathrm{~m}$ e em até $90 \%$ do percurso, o erro manteve-se abaixo de 5,70 $\mathrm{m}$ da linha teórica.

Com velocidade de deslocamento de $3,75 \mathrm{~m} \mathrm{~s}^{-1}$, utilizando DGPS, a probabilidade de erro de $50 \%$ ficou inferior a $1,75 \mathrm{~m}$ e em $90 \%$ do percurso, o erro foi inferior a 2,10 $\mathrm{m}$ da linha teórica. A mesma análise feita com os resultados obtidos sem a utilização do DGPS como guia, mostra que em $50 \%$ do percurso, o erro obtido foi menor que $2,80 \mathrm{~m}$ e em $90 \%$ do percurso, o erro manteve-se abaixo de 4,0 m da linha teórica.

Em trabalhos anteriores com metodologia e condições diferentes, foram obtidos resultados com as mesmas tendências, porém bem melhores. Vetter (1995) utilizando DGPS como guia de em veículo verificou que em $50 \%$ do percurso o erro foi inferior a 0,38 metros e em $90 \%$ do percurso esse erro foi menor que 0,94 metros. Utilizando o DGPS como guia para aplicações aéreas, Vetter (1996) verificou que em $50 \%$ do percurso, o erro foi abaixo de 0,43 metros e em $90 \%$ do percurso, o erro foi abaixo de 0,94 metros. Por sua vez, Buick (1998) comparando técnicas de orientação incluindo marcadores de espuma e dois tipos de sistemas guiados por DGPS, verificou que os sistemas guiado por DGPS, resultaram em desvio de 0,57 metros da linha central.

Molin (1998b), medindo a precisão de dois sistemas de orientação para aeronaves agrícolas (bandeiras e DGPS), verificou um erro acumulado médio de 9,7 m com bandeiras, enquanto que para a orientação com DGPS o erro foi de $0,9 \mathrm{~m}$.

Observa-se que a utilização de DGPS como guia em aplicações de faixas paralelas, mostrou maior precisão no alinhamento quando comparada com o sistema sem orientação, evidenciando assim, uma aplicação mais uniforme, que resulta em economia nas aplicações, além de diminuir os danos ao meio ambiente. 


\section{PROBABILIDADE DE ERRO DE $2,20 \mathrm{~m} \mathrm{~s}^{-1}$}

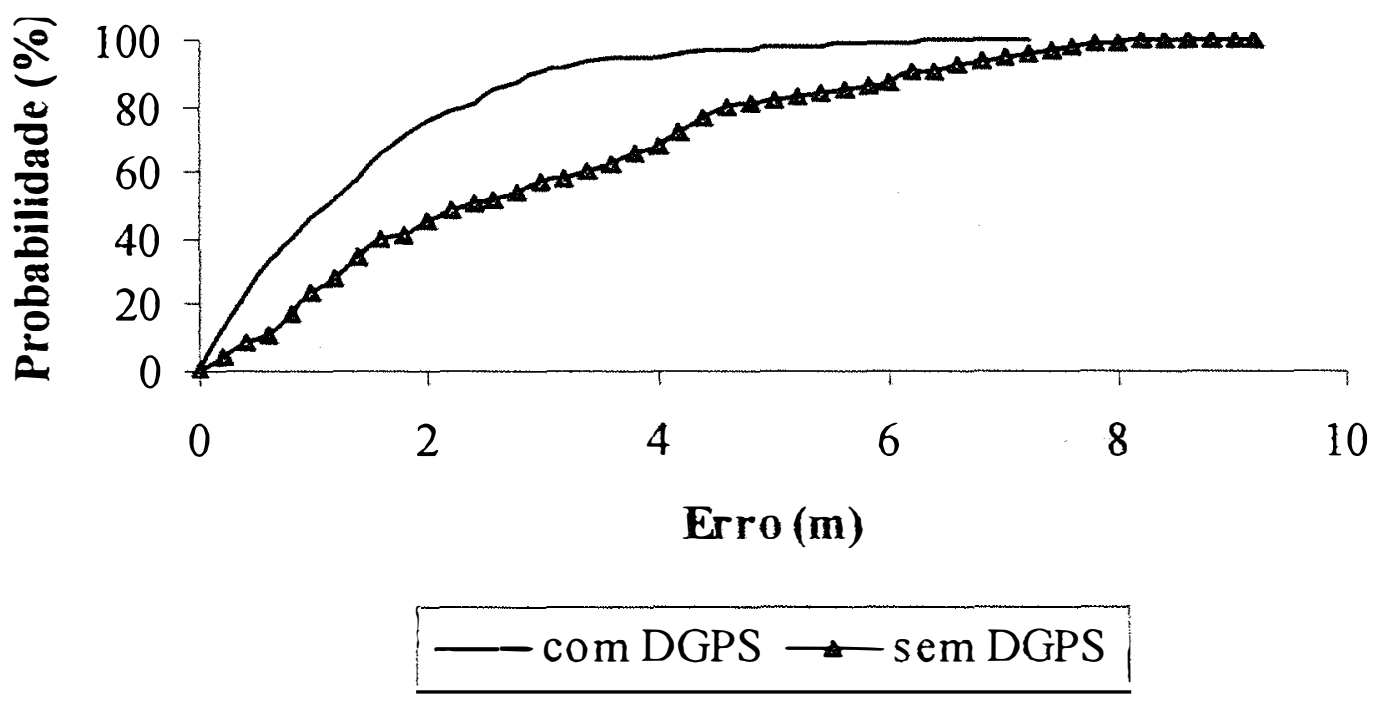

FIGURA 15. Probabilidade de erro de percurso em relação à linha teórica à velocidade de $2,20 \mathrm{~m} \mathrm{~s}^{-1}$.

\section{PROBAB ILIDADE DE ERROA $3,75 \mathrm{~m} \mathrm{~s}^{-1}$}

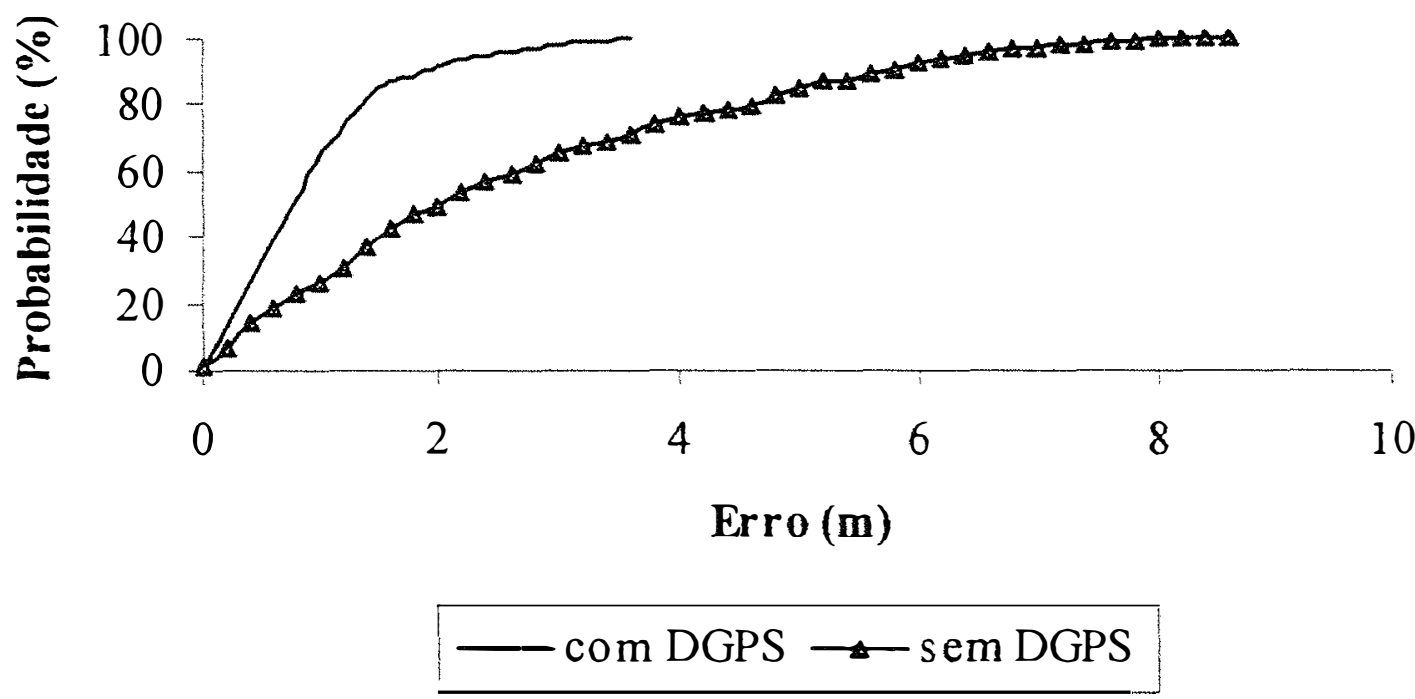

FIGURA 16. Probabilidade de erro de percurso em relação à linha teórica à velocidade de $3,75 \mathrm{~m} \mathrm{~s}^{-1}$. 
De um modo geral, verifica-se que com a utilização de DGPS a velocidade de deslocamento de $2,20 \mathrm{~m} \mathrm{~s}^{-1}$, o máximo desvio ocorrido foi de $6,90 \mathrm{~m}$. Já sem a utilização do DGPS, o máximo desvio ocorrido foi de $8,93 \mathrm{~m}$. Para a velocidade deslocamento de $3,75 \mathrm{~m} \mathrm{~s}^{-1}$, o máximo desvio ocorrido com a utilização do DGPS foi de $3,48 \mathrm{~m}$ e sem a utilização do DGPS, o máximo desvio foi de 8,33 m.

Independentemente da utilização do equipamento, a velocidade de deslocamento de $2,20 \mathrm{~m} \mathrm{~s}^{-1}$, resultou em maior erro ao longo do percurso quando comparada com a velocidade de deslocamento de $3,75 \mathrm{~m} \mathrm{~s}^{-1}$.

\subsection{Análise da influência da qualidade de percurso nas aplicações a lanço.}

Nesta etapa buscou-se quantificar a qualidade de deposição com base nos resultados de distribuição transversal, para os quatro produtos analisados nos ensaios, utilizando o erro no deslocamento gerado com e sem a utilização de DGPS como guia.

Os resultados desse estudo, apresentados nas Tabelas 10 a 13, mostram através de probabilidades de erro de 50 e $90 \%$, o efeito causado no coeficiente de variação sobre a largura efetiva de trabalho. Para tanto, utilizando-se a largura efetiva relativa a um coeficiente de variação de $15 \%$, e incerindo-se o erro de percurso aos níveis de probabilidade de 50 e $90 \%$, obteve-se os novos coeficientes de variação para cada nova largura efetiva.

Os resultados obtidos nos ensaios com calcário, são apresentados na Tabela 10. Com a utilização de DGPS, na velocidade de $2,20 \mathrm{~m} \mathrm{~s}^{-1}$, observa-se que ao acrescentar um erro com probabilidade de $50 \%(1,65 \mathrm{~m})$ sobre a largura de trabalho, o coeficiente de variação aumenta em tomo de quatro vezes em relação ao coeficiente de variação original. 
TABELA 10. Efeito do percurso com e sem sistemas de orientação e do erro assim gerado nas velocidades de deslocamento de $2,20 \mathrm{~m} \mathrm{~s}^{-1}$ e $3,75 \mathrm{~m} \mathrm{~s}^{-1}$, com probabilidades de 50 e $90 \%$, na qualidade da distribuição transversal de calcário, expressa pelo seu coeficieste de variação.

\begin{tabular}{|c|c|c|c|c|c|c|c|c|}
\hline \multirow{4}{*}{ Percurso } & \multicolumn{8}{|c|}{ Velocidade de $2,20 \mathrm{~m} \mathrm{~s}^{-1}$} \\
\hline & \multicolumn{8}{|c|}{ Probabilidade de erro de $50 \%$ com DGPS } \\
\hline & \multicolumn{4}{|c|}{ Acréscimo de $1,65 \mathrm{~m}$} & \multicolumn{4}{|c|}{ Decréscimo de $1,65 \mathrm{~m}$} \\
\hline & $\begin{array}{r}\text { Larg. Ef. } \\
\text { original }\end{array}$ & $\begin{array}{c}\text { C.V. } \\
\text { original }\end{array}$ & $\begin{array}{c}\text { Larg. Ef. } \\
\text { nova }\end{array}$ & $\begin{array}{l}\mathrm{C} . \mathrm{V} . \\
\text { novo }\end{array}$ & $\begin{array}{l}\text { Larg. Ef. } \\
\text { original }\end{array}$ & $\begin{array}{c}\mathrm{C} . \mathrm{V} . \\
\text { original }\end{array}$ & $\begin{array}{c}\text { Larg. E } \\
\text { nova }\end{array}$ & $\begin{array}{l}\text { C.V. } \\
\text { novo }\end{array}$ \\
\hline & (m) & $(\%)$ & (m) & $(\%)$ & $(\mathrm{m})$ & $(\%)$ & $(\mathrm{m})$ & $(\%)$ \\
\hline Continuo & 5,0 & 15,0 & 6,7 & 66,1 & 5,0 & 15,0 & 3,4 & 21,3 \\
\hline Esquerdo & 5,0 & 15,0 & 6,7 & 66,1 & 5,0 & 15,0 & 3,4 & 15,1 \\
\hline \multirow[t]{3}{*}{ Direito } & 5,0 & 15,0 & 6,7 & 64,3 & 5,0 & 15,0 & 3,4 & 26,6 \\
\hline & \multicolumn{8}{|c|}{ Probabilidade de erro de $90 \%$ com DGPS } \\
\hline & \multicolumn{4}{|c|}{ Acréscimo de $2,50 \mathrm{~m}$} & \multicolumn{4}{|c|}{ Decréscimo de $2,50 \mathrm{~m}$} \\
\hline Continuo & 5,0 & 15,0 & 7,5 & 75,5 & 5,0 & 15,0 & 2,5 & 7,0 \\
\hline Esquerdo & 5,0 & 15,0 & 7,5 & 72,2 & 5,0 & 15,0 & 2,5 & 9,1 \\
\hline \multirow[t]{4}{*}{ Direito } & 5,0 & 15,0 & 7,5 & 77,9 & 5,0 & 15,0 & 2,5 & 3,4 \\
\hline & \multicolumn{8}{|c|}{ Velocidade de $3,75 \mathrm{~m} \mathrm{~s}^{-1}$} \\
\hline & \multicolumn{8}{|c|}{ Probabilidade de erro de $50 \%$ com DGPS } \\
\hline & \multicolumn{4}{|c|}{ Acréscimo de $1,75 \mathrm{~m}$} & \multicolumn{4}{|c|}{ Decréscimo de $1,75 \mathrm{~m}$} \\
\hline Continuo & 5,1 & 15,0 & 6,8 & 64,3 & 5,0 & 15,0 & 3,3 & 13,7 \\
\hline Esquerdo & 5,6 & 15,0 & 7,8 & 53,9 & 6,0 & 15,0 & 4,3 & 19,1 \\
\hline \multirow[t]{3}{*}{ Direito } & 5,8 & 15,0 & 7,8 & 72,7 & 6,0 & 15,0 & 4,3 & 12,1 \\
\hline & \multicolumn{8}{|c|}{ Probabilidade de erro de $90 \%$ com DGPS } \\
\hline & \multicolumn{4}{|c|}{ Acréscimo de $2,10 \mathrm{~m}$} & \multicolumn{4}{|c|}{ Decréscimo de $2,10 \mathrm{~m}$} \\
\hline Continuo & 5,1 & 15,0 & 7,1 & 66,1 & 5,0 & 15,0 & 2,9 & 11,4 \\
\hline Esquerdo & 5,6 & 15,0 & 8,1 & 58,6 & 6,0 & 15,0 & 3,9 & 17,5 \\
\hline \multirow[t]{4}{*}{ Direito } & 5,8 & 15,0 & 8,1 & 72,1 & 6,0 & 15,0 & 3,9 & 10,4 \\
\hline & \multicolumn{8}{|c|}{ Velocidade de $2,20 \mathrm{~m} \mathrm{~s}^{-1}$} \\
\hline & \multicolumn{8}{|c|}{ Probabilidade de erro de $50 \%$ sem DGPS } \\
\hline & \multicolumn{4}{|c|}{ Acréscimo de $3,25 \mathrm{~m}$} & & Decréscin & de 3,25 & \\
\hline Continuo & 5,0 & 15,0 & 8,3 & 67,5 & 5,0 & 15,0 & 1,8 & 2,9 \\
\hline Esquerdo & 5,0 & 15,0 & 8,3 & 62,2 & 5,0 & 15,0 & 1,8 & 2,9 \\
\hline Direito & 5,0 & 15,0 & 8,3 & 73,6 & 5,0 & 15,0 & 1,8 & 2,5 \\
\hline & & & Probabil & de de e & de $90 \% \mathrm{~s}$ & DGPS & & \\
\hline & & Acréscim & de $5,70 \mathrm{~m}$ & & & Decréscir & de 5,70 & \\
\hline Continuo & 5,0 & 15,0 & 10,7 & 50,4 & 5,0 & 15,0 & $-0,7$ & $\ldots$ \\
\hline Esquerdo & 5,0 & 15,0 & 10,7 & 49,1 & 5,0 & 15,0 & $-0,7$ & $\ldots$ \\
\hline Direito & 5,0 & 15,0 & 10,7 & 51,1 & 5,0 & 15,0 & $-0,7$ & $\ldots$ \\
\hline & & & & locidac & $\mathrm{e} 3,75 \mathrm{~m} \mathrm{~s}$ & & & \\
\hline & & & Probabil & de de e & $\mathrm{de} 50 \% \mathrm{~s}$ & DGPS & & \\
\hline & & Acréscim & de $\overline{2,80 \mathrm{~m}}$ & & & Decréscir & de 2,80 & \\
\hline Contínuo & 5,1 & 15,0 & 7,8 & 73,8 & 5,0 & 15,0 & 2,2 & 6,0 \\
\hline Esquerdo & 5,6 & 15,0 & 8,8 & 58,2 & 6,0 & 15,0 & 3,2 & 11,6 \\
\hline Direito & 5,8 & 15,0 & 8,8 & 76,4 & 6,0 & 15,0 & 3,2 & 4,5 \\
\hline & & & Probabil & de de e & de $90 \% \mathrm{~s}$ & DGPS & & \\
\hline & & Acréscim & $\mathrm{de} 4,00 \mathrm{~m}$ & & & Decréscir & de 4,00 & \\
\hline Contínuo & 5,1 & 15,0 & 9,0 & 66,9 & 5,0 & 15,0 & 1,0 & 2,5 \\
\hline Esquerdo & 5,6 & 15,0 & 10,0 & 51,2 & 6,0 & 15,0 & 2,0 & 6,2 \\
\hline Direito & 5,8 & 15,0 & 10,0 & 70,4 & 6,0 & 15,0 & 2.0 & 2,5 \\
\hline
\end{tabular}


Ao se subtrair este erro com uma probabilidade de $50 \%$ (1,65 m), observa-se um aumento no coeficiente de variação, mesmo com a diminuição da largura efetiva. Este aumento é devido a grande alteração no coeficiente de variação como função da largura de trabalho, como demonstrado na Figura 10.

Quando comparou-se um acréscimo de erro com probabilidade de $90 \%(2,50 \mathrm{~m})$ sobre a largura de trabalho, o incremento no coeficiente de variação foi ainda maior. Ao considerar-se um decréscimo de erro com probabilidade de $90 \%$ (2,50 m), observa-se valores reduzidos no coeficiente de variação, em função da largura efetiva de trabalho ter sido reduzida pela metade.

Para a velocidade de deslocamento de $3,75 \mathrm{~m} \mathrm{~s}^{-1}$, acrescentando-se um erro com probabilidade de $50 \%(1,75 \mathrm{~m})$, ocorreu pouca alteração no coeficiente de variação se comparada com a probabilidade de erro relativa a velocidade de deslocamento de 2,20 $\mathrm{m} \mathrm{s}^{-1}$. Já, subtraindo-se este erro da largura de trabalho, verifica-se aumento no coeficiente de variação. Para a sobreposição do lado esquerdo da máquina, o coeficiente de variação cresce de $15 \%$ para $19,1 \%$.

Com a utilização de um erro com probabilidade de $90 \%(2,10 \mathrm{~m})$ sobre a largura de trabalho, encontram-se valores semelhantes aos observados com a utilização de erro com probabilidade de $50 \%$. No entanto as larguras efetivas são fortemente afetadas em ambos os casos.

Sem a utilização de DGPS, na velocidade de $2,20 \mathrm{~m} \mathrm{~s}^{-1}$, acrescentando-se um епто com probabilidade de $50 \%(3,25 \mathrm{~m})$ sobre a largura de trabalho, o coeficiente de variação aumentou, em média para $67,5 \%$. Ao subtrair este erro sobre a largura de trabalho, o coeficiente de variação foi reduzido para valores entre 2,5 e $2,9 \%$, dependendo do tipo de percurso utilizado. Ao acrescer um erro com probabilidade de 90 $\%$ (5,70 m), observa-se uma redução no coeficiente de variação em relação ao erro com probabilidade de $50 \%(3,25 \mathrm{~m})$, refletindo a grande alteração nas curvas obtidas de coeficiente de variação como função da largura efetiva de trabalho. Entretanto, ao subtrair-se um erro com probabilidade de $90 \%$ (5,70 m), encontram-se valores de larguras efetivas negativas. 
$\mathrm{Na}$ velocidade de deslocamento de $3,75 \mathrm{~m} \mathrm{~s}^{-1}$, verifica-se o mesmo comportamento do coeficiente de variação ao comparar um erro com probabilidade de $50 \%(2,80 \mathrm{~m})$, com um erro com probabilidade de $90 \%(4,00 \mathrm{~m})$. É interessante ressaltar que quando se compara a influência ao diminuir o erro, tanto para a probabilidade de $50 \%(2,80 \mathrm{~m})$ como para a probabilidade de $90 \%(4,00 \mathrm{~m})$, observa-se valores baixos de coeficiente de variação, porém, com larguras efetivas de trabalho inviáveis para este tipo de aplicação.

$\mathrm{Na}$ Tabela 11, são apresentados os resultados obtidos referente ao efeito do percurso com e sem sistemas de orientação na análise de distribuição transversal de adubo. Com a utilização de DGPS como guia, na velocidade de deslocamento de 2,20 $\mathrm{m} \mathrm{s}^{-1}$, acrescentando-se um erro com probabilidade de $50 \%$, houve pouca alteração no coeficiente de variação. Com isso, a largura efetiva de trabalho aumentou de um intervalo de 4,0 a 6,3 m para 5,7 a 7,7 m. Já, quando este erro foi decrescido, observamse valores semelhantes de coeficiente de variação a aqueles obtidos com o acréscimo de erro, ocorrendo uma diminuição na largura efetiva para o intervalo entre 2,4 a 4,4 m, dependendo do sistema de percurso utilizado. Para um erro com probabilidade de $90 \%$, o coeficiente de variação aumenta em até duas vezes. Ao diminuir este erro com probabilidade de $90 \%$, o coeficiente de variação variou de 5,1 a 17,6\%, entretanto, a largura efetiva de trabalho reduziu para 1,5 a 3,5 m, dependendo do tipo de percurso.

$\mathrm{Na}$ velocidade de deslocamento de $3,75 \mathrm{~m} \mathrm{~s}^{-1}$, ocorreu um aumento de duas vezes na largura efetiva obtida em relação a velocidade de deslocamento de $2,20 \mathrm{~m} \mathrm{~s}^{-1}$. Isso não seria esperado, uma vez que, com o aumento de velocidade a largura efetiva não deveria ter sido alterada. Além disso, ao acrescer ou decrescer o erro independente da probabilidade, os valores de coeficiente de variação foram semelhantes. 
TABELA 11. Efeito do petcurso com e sem sistemas de orientação e do erro assim getado nas velocidades de deslocamento de $2,20 \mathrm{~m} \mathrm{~s}^{-1}$ e $3,75 \mathrm{~m} \mathrm{~s}^{-1}$, com probabilidades de $50 \%$ e $90 \%$, na qualidade da distribuição transversal de adubo, expressa pelo seu coeficiente de variação.

\begin{tabular}{|c|c|c|c|c|c|c|c|c|}
\hline \multirow{4}{*}{ Percurso } & \multicolumn{8}{|c|}{ Velocidade de $2,20 \mathrm{~m} \mathrm{~s}^{-1}$} \\
\hline & \multicolumn{8}{|c|}{ Probabilidade de erro de $50 \%$ com DGPS } \\
\hline & \multicolumn{4}{|c|}{ Acréscimo de $1,65 \mathrm{~m}$} & \multicolumn{4}{|c|}{ Decréscimo de $1,65 \mathrm{~m}$} \\
\hline & $\begin{array}{c}\text { Larg. Ef. } \\
\text { original }\end{array}$ & $\begin{array}{c}\text { C.V. } \\
\text { original }\end{array}$ & $\begin{array}{c}\text { Larg. Ef. } \\
\text { nova }\end{array}$ & $\begin{array}{l}\text { C.V. } \\
\text { novo }\end{array}$ & $\begin{array}{l}\text { Larg. Ef. } \\
\text { original }\end{array}$ & $\begin{array}{c}\mathrm{C} . \mathrm{V} . \\
\text { original }\end{array}$ & $\begin{array}{c}\text { Larg. E } \\
\text { nova }\end{array}$ & $\begin{array}{l}\text { C.V. } \\
\text { novo }\end{array}$ \\
\hline & (m) & $(\%)$ & (m) & $(\%)$ & $(\mathrm{m})$ & $(\%)$ & $(\mathrm{m})$ & $(\%)$ \\
\hline Contínuo & 4,0 & 15,0 & 5,7 & 19,1 & 4,0 & 15,0 & 2,4 & 8,6 \\
\hline Esquerdo & 6,3 & 15,0 & 7,7 & 26,7 & 6,0 & 15,0 & 4,4 & 17,0 \\
\hline \multirow[t]{3}{*}{ Direito } & 6,0 & 15,0 & 7,7 & 17,9 & 6,0 & 15,0 & 4,4 & 22,1 \\
\hline & \multicolumn{8}{|c|}{ Probabilidade de erro de $90 \%$ com DGPS } \\
\hline & \multicolumn{4}{|c|}{ Acréscimo de $2,50 \mathrm{~m}$} & \multicolumn{4}{|c|}{ Decréscimo de 2,50 m } \\
\hline Contínuo & 4,0 & 15,0 & 6,5 & 21,7 & 4,0 & 15,0 & 1,5 & 5,1 \\
\hline Esquerdo & 6,3 & 15,0 & 8,5 & 31,0 & 6,0 & 15,0 & 3,5 & 13,8 \\
\hline \multirow[t]{4}{*}{ Direito } & 6,0 & 15,0 & 8,5 & 19,6 & 6,0 & 15,0 & 3,5 & 17,6 \\
\hline & \multicolumn{8}{|c|}{ Velocidade de $3,75 \mathrm{~m} \mathrm{~s}^{-1}$} \\
\hline & \multicolumn{8}{|c|}{ Probabilidade de erro de $50 \%$ com DGPS } \\
\hline & \multicolumn{4}{|c|}{ Acréscimo de $1,75 \mathrm{~m}$} & \multicolumn{4}{|c|}{ Decréscimo de $1,75 \mathrm{~m}$} \\
\hline Contínuo & 11,0 & 15,0 & 12,8 & 25,4 & 11,0 & 15,0 & 9,3 & 25,8 \\
\hline Esquerdo & 11,8 & 15,0 & 13,8 & 19,5 & 12,0 & 15,0 & 10,3 & 26,8 \\
\hline \multirow[t]{3}{*}{ Direito } & 10,9 & 15,0 & 12,8 & 30,0 & 11,0 & 15,0 & 9,3 & 28,1 \\
\hline & \multicolumn{8}{|c|}{ Probabilidade de erro de $90 \%$ com DGPS } \\
\hline & \multicolumn{4}{|c|}{ Acréscimo de $2,10 \mathrm{~m}$} & \multicolumn{4}{|c|}{ Decréscimo de $2,10 \mathrm{~m}$} \\
\hline Contínuo & 11,0 & 15,0 & 13,1 & 25,4 & 11,0 & 15,0 & 8,9 & 25,8 \\
\hline Esquerdo & 11,8 & 15,0 & 14,1 & 19,3 & 12,0 & 15,0 & 9,9 & 21,6 \\
\hline \multirow[t]{4}{*}{ Direito } & 10,9 & 15,0 & 13,1 & 30,2 & 11,0 & 15,0 & 8,9 & 27,9 \\
\hline & \multicolumn{8}{|c|}{ Velocidade de $2,20 \mathrm{~m} \mathrm{~s}^{-1}$} \\
\hline & \multicolumn{8}{|c|}{ Probabilidade de erro de $50 \%$ sem DGPS } \\
\hline & \multicolumn{4}{|c|}{ Acréscimo de $3,25 \mathrm{~m}$} & & Decréscir & de 3,25 & \\
\hline Continuo & 4,0 & 15,0 & 7,3 & 25,1 & 4,0 & 15,0 & 0,8 & 0,8 \\
\hline Esquerdo & 6,3 & 15,0 & 9,3 & 36,2 & 6,0 & 15,0 & 2,8 & 9,8 \\
\hline Direito & 6,0 & 15,0 & 9,3 & 22,5 & 6,0 & 15,0 & 2,8 & 12,1 \\
\hline & & & Probabil & de de e & de $90 \% \mathrm{~s}$ & DGPS & & \\
\hline & & Acréscin & de $5,70 \mathrm{~m}$ & & & Decrésci & de 5,70 & \\
\hline Contínuo & 4,0 & 15,0 & 9,7 & 32,0 & 4,0 & 15,0 & $-1,7$ & $\cdots$ \\
\hline Esquerdo & 6,3 & 15,0 & 11,7 & 47,2 & 6,0 & 15,0 & 0,3 & 1,4 \\
\hline Direito & 6,0 & 15,0 & 11,7 & 28,9 & 6,0 & 15,0 & 0,3 & 0,5 \\
\hline & & & & locidac & $\mathrm{le} 3,75 \mathrm{~m} \mathrm{~s}$ & & & \\
\hline & & & Probabil & de de e & de $50 \% \mathrm{~s}$ & DGPS & & \\
\hline & & Acréscin & de $2,80 \mathrm{~m}$ & & & Decrésci & de 2,80 & \\
\hline Continuo & 11,0 & 15,0 & 13,8 & 25,3 & 11,0 & 15,0 & 8,2 & 25,9 \\
\hline Esquerdo & 11,8 & 15,0 & 14,8 & 18,9 & 12,0 & 15,0 & 9,2 & 21,9 \\
\hline Direito & 10,9 & 15,0 & 13,8 & 30,6 & 11,0 & 15,0 & 8,2 & 27,5 \\
\hline & & & Probabi & de de e & de $90 \% \mathrm{~s}$ & DGPS & & \\
\hline & & Acréscin & de $4,00 \mathrm{~m}$ & & & Decrésci & de 4,00 & \\
\hline Continuo & 11,0 & 15,0 & 15,0 & 25,1 & 11,0 & 15,0 & 7,0 & 26,0 \\
\hline Esquerdo & 11,8 & 15,0 & 16,0 & 18,3 & 12,0 & 15,0 & 8,0 & 25,3 \\
\hline Direito & 10,9 & 15,0 & 15,0 & 31,2 & 11,0 & 15,0 & 7,0 & 26,8 \\
\hline
\end{tabular}


Sem a utilização de DGPS como guia, na velocidade de deslocamento de 2,20 $\mathrm{m} \mathrm{s}^{-1}$, e acrescentando-se um erro com probabilidade de $50 \%$ (3,25 m) sobre a largura de trabalho, o coeficiente de variação foi alterado para o intervalo de 22,5 a $36,2 \%$, dependendo do tipo de percurso. Com a diminuição deste erro, o coeficiente de variação foi reduzido de 0,8 a $12,1 \%$; entretanto, as larguras efetivas de trabalho, tomaram-se inviáveis.

Para um erro com probabilidade de $90 \%(5,70 \mathrm{~m})$, o coeficiente de variação aumentou em até três vezes se comparado com o valor encontrado com a largura efetiva original. Porém, com o decréscimo deste erro, encontraram-se valores de largura efetiva baixos e até nulos, dependendo do sistema de percurso utilizado.

Com a velocidade de deslocamento de $3,75 \mathrm{~m} \mathrm{~s}^{-1}$, os valores de coeficiente de variação foram de 18,9 a 30,6 \%, e a largura efetiva de trabalho aumentou de 10,9 a 11,8 m para 13,1 a 14,1 m. Com a diminuição deste erro obteve-se valores semelhantes de coeficiente de variação, mas com larguras efetivas reduzidas para valores entre 8,2 a 9,2 $\mathrm{m}$.

Analisando um erro com probabilidade de $90 \%(4,00 \mathrm{~m})$, verifica-se praticamente os mesmos valores de coeficiente de variação. Entretanto, as larguras efetivas de trabalho resultaram em valores entre 15,0 e $16,0 \mathrm{~m}$ ao acrescer este erro e larguras efetivas de 7,0 a 8,0 m ao diminuir este erro sobre a largura original.

O aumento da velocidade de $2,20 \mathrm{~m} \mathrm{~s}^{-1}$ para $3,75 \mathrm{~m} \mathrm{~s}^{-1}$, resultou na duplicação do valor de largura efetiva. Este aumento decorre da granulometria do produto que permite que este seja lançado a maiores distâncias do que os demais para uma mesma regulagem da máquina. A influência da granulometria do produto na eficiência de aplicação já foi citada por outros autores, como Balastreire e Coelho (1992) e Mialhe (1996).

Os resultados obtidos nos ensaios com uréia, são apresentados na Tabela 12. Para a velocidade de deslocamento de $2,20 \mathrm{~m} \mathrm{~s}^{-1}$, com a utilização de DGPS, acrescentandose um erro com probabilidade de $50 \%$, o novo coeficiente de variação resultou em valores entre 22,1 e $29,4 \%$. Já com o decréscimo deste erro, obteve-se valores de coeficiente de variação de 6,0 a $17,3 \%$. Neste caso, a utilização de um valor baixo de 
coeficiente de variação implicaria na obtenção de uma largura efetiva inviável para este tipo de aplicação.

Ao acrescer um erro com probabilidade de $90 \%$ sobre a largura de trabalho, obteve-se valores de coeficiente de variação duas vezes maiores que o coeficiente de variação original. A largura de trabalho, variou de 5,5 a 8,0 m, dependendo do tipo de percurso. Subtraindo-se o erro com probabilidade de $90 \%$, resultou em decréscimo nos valores de coeficiente de variação e valor de largura efetiva insatisfatórios.

$\mathrm{Na}$ velocidade de $3,75 \mathrm{~m} \mathrm{~s}^{-1}$, ao acrescer um erro com probabilidade de $50 \%$ $(1,75 \mathrm{~m})$, observa-se um aumento no coeficiente de variação de 1,1 a $14,8 \%$ em relação ao coeficiente de variação original. Este fato também pode ser observado para um erro com probabilidade de $90 \%$. Ao subtrair-se este erro, tanto para probabilidade de $50 \%$ como de $90 \%$, os valores de coeficiente de variação são semelhantes.

Sem a utilização de DGPS, na velocidade de $2,20 \mathrm{~m} \mathrm{~s}^{-1}$, ao acrescer um erro com probabilidade de $50 \%$, obteve-se valores de coeficiente de variação duas vezes maiores do que os encontrados com o coeficiente de variação original. Já ao acrescer o erro com probabilidade de $90 \%$, o coeficiente de variação aumentou em três vezes e a largura efetiva de trabalho aumentou para valores entre 5,5 e 11,2 m. Subtraindo-se os valores referentes aos erros sobre a largura de trabalho, obteve-se valores de coeficiente de variação nulos.

$\mathrm{Na}$ velocidade de $3,75 \mathrm{~m} \mathrm{~s}^{-1}$, ao acrescer um erro tanto com probabilidade de 50 $\%$ como de $90 \%$, observou-se valores de coeficiente de variação semelhantes. Entretanto, na largura de trabalho com probabilidade de $90 \%$, os resultados foram mais satisfatórios. Com a subtração deste erro, obteve-se valores de coeficiente de variação baixos, porém com larguras de trabalho inviáveis. 
TABELA 12. Efeito do percurso com e sem sistemas de orientação e do erro assim gerado nas velocidades de deslocamento de $2,20 \mathrm{~m} \mathrm{~s}^{-1}$ e $3,75 \mathrm{~m} \mathrm{~s}^{-1}$, com probabilidades de $50 \%$ e $90 \%$, na qualidade da distribuição transversal de uréia, expressa pelo seu coeficiente de variação.

\begin{tabular}{|c|c|c|c|c|c|c|c|c|}
\hline \multirow{4}{*}{ Percurso } & \multicolumn{8}{|c|}{ Velocidade de $2,20 \mathrm{~m} \mathrm{~s}^{-1}$} \\
\hline & \multicolumn{8}{|c|}{ Probabilidade de erro de $50 \%$ com DGPS } \\
\hline & \multicolumn{4}{|c|}{ Acréscimo de $1,65 \mathrm{~m}$} & \multicolumn{4}{|c|}{ Decréscimo de $1,65 \mathrm{~m}$} \\
\hline & $\begin{array}{c}\text { Larg. Ef. } \\
\text { original }\end{array}$ & $\begin{array}{c}\text { C.V. } \\
\text { original }\end{array}$ & $\begin{array}{c}\text { Larg. Ef. } \\
\text { nova }\end{array}$ & $\begin{array}{l}\text { C.V. } \\
\text { novo }\end{array}$ & $\begin{array}{r}\text { Larg. Ef. } \\
\text { original }\end{array}$ & $\begin{array}{c}\mathrm{C} . \mathrm{V} . \\
\text { original }\end{array}$ & $\begin{array}{c}\text { Larg. Ef. } \\
\text { nova }\end{array}$ & $\begin{array}{l}\text { C.V. } \\
\text { novo }\end{array}$ \\
\hline & (m) & $(\%)$ & (m) & $(\%)$ & (m) & $(\%)$ & (m) & $(\%)$ \\
\hline Continuo & 3,5 & 15,0 & 5,2 & 22,1 & 3,5 & 15,0 & 1,9 & 7,6 \\
\hline Esquerdo & 3,4 & 15,0 & 4,7 & 22,4 & 3,0 & 15,0 & 1,4 & 6,0 \\
\hline \multirow[t]{3}{*}{ Direito } & 5,5 & 15,0 & 7,2 & 29,4 & 5,5 & 15,0 & 3,9 & 17,3 \\
\hline & \multicolumn{8}{|c|}{ Probabilidade de erro de $90 \%$ com DGPS } \\
\hline & \multicolumn{4}{|c|}{ Acréscimo de $2,50 \mathrm{~m}$} & \multicolumn{4}{|c|}{ Decréscimo de $2,50 \mathrm{~m}$} \\
\hline Continuo & 3,5 & 15,0 & 6,0 & 25,9 & 3,5 & $15, \overline{0}$ & 1,0 & 3,9 \\
\hline Esquerdo & 3,4 & 15,0 & 5,5 & 26,6 & 3,0 & 15,0 & 0,5 & 1,8 \\
\hline \multirow[t]{4}{*}{ Direito } & 5,5 & 15,0 & 8,0 & 32,5 & 5,5 & 15,0 & 3,0 & 14,2 \\
\hline & \multicolumn{8}{|c|}{ Velocidade de $3,75 \mathrm{~m} \mathrm{~s}^{-1}$} \\
\hline & \multicolumn{8}{|c|}{ Probabilidade de erro de $50 \%$ com DGPS } \\
\hline & \multicolumn{4}{|c|}{ Acréscimo de $1,75 \mathrm{~m}$} & \multicolumn{4}{|c|}{ Decréscimo de $1,75 \mathrm{~m}$} \\
\hline Contínuo & 5,1 & 15,0 & 6,8 & 20,3 & 5,0 & 15,0 & 3,3 & 11,5 \\
\hline Esquerdo & 5,9 & 15,0 & 7,8 & 16,1 & 6,0 & 15,0 & 4,3 & 8,3 \\
\hline \multirow[t]{3}{*}{ Direito } & 5,3 & 15,0 & 6,8 & 29,8 & 5,0 & 15,0 & 3,3 & 16,1 \\
\hline & \multicolumn{8}{|c|}{ Probabilidade de erro de $90 \%$ com DGPS } \\
\hline & \multicolumn{4}{|c|}{ Acréscimo de $2,10 \mathrm{~m}$} & \multicolumn{4}{|c|}{ Decréscimo de $2,10 \mathrm{~m}$} \\
\hline Continuo & 5,1 & 15,0 & 7,1 & 21,2 & 5,0 & 15,0 & 2,9 & 10,6 \\
\hline Esquerdo & 5,9 & 15,0 & 8,1 & 16,9 & 6,0 & 15,0 & 3,9 & 7,5 \\
\hline \multirow[t]{4}{*}{ Direito } & 5,3 & 15,0 & 7,1 & 31,2 & 5,0 & 15,0 & 2,9 & 14,7 \\
\hline & \multicolumn{8}{|c|}{ Velocidade de $2,20 \mathrm{~m} \mathrm{~s}^{-1}$} \\
\hline & \multicolumn{8}{|c|}{ Probabilidade de erro de $50 \%$ sem DGPS } \\
\hline & \multicolumn{4}{|c|}{ Acréscimo de $3,25 \mathrm{~m}$} & & Decréscir & de $3,25 n$ & \\
\hline Contínuo & 3,5 & 15,0 & 6,8 & 30,4 & 3,5 & 15,0 & 0,3 & - \\
\hline Esquerdo & 3,4 & 15,0 & 6,3 & 31,6 & 3,0 & 15,0 & $-0,3$ & $\cdots$ \\
\hline Direito & 5,5 & 15,0 & 8,8 & 36,2 & 5,5 & 15,0 & 2,3 & 10,5 \\
\hline & & & Probabi & de de e & de $90 \%$ s & DGPS & & \\
\hline & & Acréscim & de $5,70 \mathrm{~m}$ & & & Decréscir & de $5,70 \mathrm{n}$ & \\
\hline Continuo & 3,5 & 15,0 & 9,2 & 40,0 & 3,5 & 15,0 & $-2,2$ & $-\cdots$ \\
\hline Esquerdo & 3,4 & 15,0 & 8,7 & 42,4 & 3,0 & 15,0 & $-2,7$ & - \\
\hline Direito & 5,5 & 15,0 & 11,2 & 44,2 & 5,5 & 15,0 & $-0,2$ & $\ldots$ \\
\hline & & & & locidac & e $3,75 \mathrm{~m} \mathrm{~s}$ & & & \\
\hline & & & Probabi & de de e & de $50 \% s$ & DGPS & & \\
\hline & & Acréscim & de $2,80 \mathrm{~m}$ & & & Decréscir & de $2,80 \mathrm{r}$ & \\
\hline Continuo & 5,1 & 15,0 & 7,8 & 22,9 & 5,0 & 15,0 & 2,2 & 8,9 \\
\hline Esquerdo & 5,9 & 15,0 & 8,8 & 18,5 & 6,0 & 15,0 & 3,2 & 5,9 \\
\hline Direito & 5,3 & 15,0 & 7,8 & 33,9 & 5,0 & 15,0 & 2,2 & 12,0 \\
\hline & & & Probabi & de de e & de $90 \%$ s & DGPS & & \\
\hline & & Acréscim & de $4,00 \mathrm{~m}$ & & & Decréscir & de $4,00 \mathrm{r}$ & \\
\hline Continuo & 5,1 & 15,0 & 9,0 & 25,9 & 5,0 & 15,0 & 1,0 & 5,9 \\
\hline Esquerdo & 5,9 & 15,0 & 10,0 & 25,9 & 6,0 & 15,0 & 2,0 & 3,2 \\
\hline Direito & 5,3 & 15,0 & 9,0 & 38,7 & 5,0 & 15,0 & 1,0 & 7,2 \\
\hline
\end{tabular}


A Tabela 13 apresenta os resultados obtidos nos ensaios com aveia. Com a utilização de DGPS, na velocidade de $2,20 \mathrm{~m} \mathrm{~s}^{-1}$, observa-se que ao acrescer um erro com probabilidade de $50 \%$, o coeficiente de variação aumentou em até duas vezes em relação ao coeficiente original.

Subtraindo da largura efetiva o valor equivalente ao erro, o coeficiente de variação foi reduzido em média para $10 \%$. Porém a largura efetiva resultou insatisfatória. Analisando um erro com probabilidade de $90 \%$, observa-se um coeficiente de variação com sobreposição do lado direito de $24,3 \%$, com largura efetiva aumentando para 7,5 m. Ao subtrair este erro, obtém-se os resultados semelhantes de coeficiente de variação ao apresentados com probabilidade de $50 \%$. Estes resultados podem ser devido a grande alteração nos resultados simulados do coeficiente de variação como função da largura efetiva obtidos a partir dos ensaios de distribuição transversal. Outro fator que provavelmente poderia influenciar nestes resultados é quanto a granulometria do produto aplicado, já que para autores como Hofstee e Huisman (1990), a performance dos distribuidores depende muito das características físicas dos produtos.

Para a velocidade de deslocamento de $3,75 \mathrm{~m} \mathrm{~s}^{-1}$, com um acréscimo ou subtração de larguras de erro tanto para as probabilidades de $50 \%$ como de $90 \%$, os valores observados são semelhantes.

Sem a utilização de DGPS, o efeito do erro de percurso, causou grande alteração no coeficiente de variação para as duas velocidades testadas. Além disso, a largura de trabalho variou bastante quando acrescidos os valores equivalentes aos erros e com a subtração dos mesmos, observam-se valores nulos de largura efetiva. 
TABELA 13. Efeito do percurso com e sem sistemas de orientação e do erro assim gerado nas velocidades de deslocamento de $2,20 \mathrm{~m} \mathrm{~s}^{-1}$ e $3,75 \mathrm{~m} \mathrm{~s}^{-1}$, com probabilidades de $50 \%$ e $90 \%$, na qualidade da distribuição transversal de aveia, expressa pelo seu coeficiente de variação.

\begin{tabular}{|c|c|c|c|c|c|c|c|c|}
\hline \multirow{4}{*}{ Percurso } & \multicolumn{8}{|c|}{ Velocidade de $2,20 \mathrm{~m} \mathrm{~s}^{-1}$} \\
\hline & \multicolumn{8}{|c|}{ Probabilidade de erro de $50 \%$ com DGPS } \\
\hline & \multicolumn{4}{|c|}{ Acréscimo de $1,65 \mathrm{~m}$} & \multicolumn{4}{|c|}{ Decréscimo de $1,65 \mathrm{~m}$} \\
\hline & $\begin{array}{r}\text { Larg. Ef. } \\
\text { original }\end{array}$ & $\begin{array}{l}\text { C.V. } \\
\text { original }\end{array}$ & $\begin{array}{c}\text { Larg. Ef. } \\
\text { nova }\end{array}$ & $\begin{array}{l}\text { C.V. } \\
\text { novo }\end{array}$ & $\begin{array}{l}\text { Larg. Ef. } \\
\text { original }\end{array}$ & $\begin{array}{l}\text { C.V. } \\
\text { original }\end{array}$ & $\begin{array}{c}\text { Larg. Ef } \\
\text { nova }\end{array}$ & $\begin{array}{l}\text { C.V. } \\
\text { novo }\end{array}$ \\
\hline & (m) & $(\%)$ & (m) & $(\%)$ & (m) & $(\%)$ & (m) & $(\%)$ \\
\hline Continuo & 3,3 & 15,0 & 4,7 & 31,3 & 3,0 & 15,0 & 1,4 & 11,0 \\
\hline Esquerdo & 3,8 & 15,0 & 5,7 & 27,5 & 4,0 & 15,0 & 2,4 & 9,3 \\
\hline \multirow[t]{3}{*}{ Direito } & 4,9 & 15,0 & 6,7 & 21,6 & 5,0 & 15,0 & 3,4 & 10,9 \\
\hline & \multicolumn{8}{|c|}{ Probabilidade de erro de $90 \%$ com DGPS } \\
\hline & \multicolumn{4}{|c|}{ Acréscimo de $2,50 \mathrm{~m}$} & \multicolumn{4}{|c|}{ Decréscimo de $2,50 \mathrm{~m}$} \\
\hline Contínuo & $\overline{3,3}$ & 15,0 & 5,5 & 36,5 & 3,0 & 15,0 & 0,5 & 5,7 \\
\hline Esquerdo & 3,8 & 15,0 & 6,5 & 32,2 & 4,0 & 15,0 & 1,5 & 4,6 \\
\hline \multirow[t]{4}{*}{ Direito } & 4,9 & 15,0 & 7,5 & 24,3 & 5,0 & 15,0 & 2,5 & 8,2 \\
\hline & \multicolumn{8}{|c|}{ Velocidade de $3,75 \mathrm{~m} \mathrm{~s}^{-1}$} \\
\hline & \multicolumn{8}{|c|}{ Probabilidade de erro de $50 \%$ com DGPS } \\
\hline & \multicolumn{4}{|c|}{ Acréscimo de $1,75 \mathrm{~m}$} & \multicolumn{4}{|c|}{ Decréscimo de $1,75 \mathrm{~m}$} \\
\hline Contínuo & 3,2 & 15,0 & 4,8 & 21,8 & 3,0 & 15,0 & 1,3 & 4,8 \\
\hline Esquerdo & 5,3 & 15,0 & 6,8 & 34,5 & 5,0 & 15,0 & 3,3 & 16,0 \\
\hline \multirow[t]{3}{*}{ Direito } & 4,6 & 15,0 & 6,8 & 25,0 & 5,0 & 15,0 & 3,3 & 10,5 \\
\hline & \multicolumn{8}{|c|}{ Probabilidade de erro de $90 \%$ com DGPS } \\
\hline & \multicolumn{4}{|c|}{ Acréscimo de $2,10 \mathrm{~m}$} & \multicolumn{4}{|c|}{ Decréscimo de $2,10 \mathrm{~m}$} \\
\hline Continuo & 3,2 & 15,0 & 5,1 & 23,5 & 3,0 & 15,0 & 0,9 & 3,1 \\
\hline Esquerdo & 5,3 & 15,0 & 7,1 & 36,4 & 5,0 & 15,0 & 2,9 & 14,1 \\
\hline \multirow[t]{4}{*}{ Direito } & 4,6 & 15,0 & 7,1 & 26,4 & 5,0 & 15,0 & 2,9 & 9,0 \\
\hline & \multicolumn{8}{|c|}{ Velocidade de $2,20 \mathrm{~m} \mathrm{~s}^{-1}$} \\
\hline & \multicolumn{8}{|c|}{ Probabilidade de erro de $50 \%$ sem DGPS } \\
\hline & \multicolumn{4}{|c|}{ Acréscimo de $3,25 \mathrm{~m}$} & & Decréscir & de $3,25 \mathrm{r}$ & \\
\hline Continuo & 3,3 & 15,0 & 6,3 & 42,8 & 3,0 & 15,0 & $-0,3$ & $\ldots$ \\
\hline Esquerdo & 3,8 & 15,0 & 7,3 & 38,9 & 4,0 & 15,0 & 0,8 & $\ldots$ \\
\hline Direito & 4,9 & 15,0 & 8,3 & 27,6 & 5,0 & 15,0 & 1,8 & 4,9 \\
\hline & & & Probabil & de de e & de $90 \%$ s & DGPS & & \\
\hline & & Acréscim & de $5,70 \mathrm{~m}$ & & & Decrésci & de $5,70_{1}$ & \\
\hline Continuo & 3,3 & 15,0 & 8,7 & 33,5 & 3,0 & 15,0 & $-2,7$ & $\ldots$ \\
\hline Esquerdo & 3,8 & 15,0 & 9,7 & 20,2 & 4,0 & 15,0 & $-1,7$ & $\ldots$ \\
\hline Direito & 4,9 & 35,0 & 10,7 & 45,3 & 5,0 & 15,0 & $-0,7$ & -.... \\
\hline & & & & locidac & e $3,75 \mathrm{~ms}$ & & & \\
\hline & & & Probabi & de de e & $\operatorname{de} 50 \%$ & DGPS & & \\
\hline & & Acréscim & de $2,80 \mathrm{~m}$ & & & Decrésci & de 2,80 & \\
\hline Continuo & 3,2 & 15,0 & 5,8 & 26,9 & 3,0 & 15,0 & 0,2 & $\ldots$ \\
\hline Esquerdo & 5,3 & 15,0 & 7,8 & 40,1 & 5,0 & 15,0 & 2,2 & 10,4 \\
\hline Direito & 4,6 & 15,0 & 7,8 & 29,3 & 5,0 & 15,0 & 2,2 & 3,2 \\
\hline & & & Probabi & de de e & de $90 \%$ & DGPS & & \\
\hline & & Acréscim & de $4,00 \mathrm{~m}$ & & & Decréscir & de $4,00 \mathrm{r}$ & \\
\hline Continuo & 3,2 & 15,0 & 7,0 & 32,7 & 3,0 & 15,0 & $-1,0$ & $-\cdots$ \\
\hline Esquerdo & 5,3 & 15,0 & 9,0 & 46,4 & 5,0 & 15,0 & 1,0 & 4,0 \\
\hline Direito & 4,6 & 15,0 & 9,0 & 34,3 & 5,0 & 15,0 & 1,0 & 1,2 \\
\hline
\end{tabular}


De maneira geral, com e sem a utilização de DGPS como guia nas aplicações em faixas, percebe-se uma influência fortemente negativa na qualidade das aplicações. Pode-se, então, constatar que em campo a utilização de DGPS como guia nas aplicações em faixas paralelas tem melhores resultados com adubos, uréia e aveia. Entretanto, para calcário foram obtidos resultados semelhantes nas duas condições. Porém, de maneira geral, a utilização de DGPS como guia de aplicação de faixas paralelas, proporcionou maior precisão no alinhamento, sendo interessante a fim de minimizar o erro de percurso, tomando as aplicações em faixas paralelas retas mais eficientes.

É importante ressaltar que os erro de percurso causam excesso ou falta de produto aplicado. Nos locais em que são aplicados em excesso, causam além dos danos ao meio ambiente, aumento nos custos. Já aplicações em menor quantidade que as necessárias provocam considerável perda em produtividade (Tourino, 1986).

Através dos resultados obtidos na análise da influência da qualidade de percurso nas aplicações a lanço, observa-se grande alteração na largura efetiva. Com o acréscimo de erro sobre a largura efetiva original, resulta num aumento da nova largura efetiva. Entretanto, para calcário, este aumento resulta na obtenção de coeficiente de variação com valores entre 49,1 e 77,9 \%, considerados muito altos (acima de $30 \%$ ) conforme Pimentel (1987). Já para adubo, uréia e aveia, este aumento no coeficiente de variação como função da largura efetiva variou na ordem de 16,1 a 46,4\%, dependendo do sistema de percurso utilizado.

A subtração do erro de percurso com a utilização de DGPS, resultou na obtenção de larguras efetivas muito baixas e como consequência coeficiente de variação baixos. No caso dos resultados sem a utilização de DGPS, a largura efetiva chegou à valores negativos. Portanto, pode-se inferir que os erros de percurso obtidos nos ensaios são fatores que influem fortemente na qualidade das aplicações a lanço. Desta maneira é justificável o aprofundamendo nos estudo dos erros de percurso, visto que estes possuem importância econômica e ambiental. A partir disso, novos estudos devem ser realizados com outros produtos e outras máquinas. 


\section{CONCLUSÕES}

A partir dos resultados obtidos neste estudo, pode-se concluir que com o aumento da velocidade de deslocamento do distribuidor a lanço de $2,20 \mathrm{~m} \mathrm{~s}^{-1}$ para $3,75 \mathrm{~m} \mathrm{~s}^{-1}$, ocorreu maior variação no perfil de distribuição para adubo e uréia. No caso de calcário e aveia, a velocidade de deslocamento não teve maior influência no perfil de distribuição transversal.

A metodologia proposta de utilização de um disco de corte para traçar o percurso do trator marcando o solo, apresentou resultados satisfatórios, sendo possível a obtenção de leituras de desvios nos percursos com precisão centimétrica.

Além do coeficiente de variação, o erro de percurso é um fator importante que deve ser analisado, a fim de melhorar a qualidade das aplicações a lanço.

A qualidade dos percursos guiados por barra de luz provavelmente tenha sido afetada pela falta de treinamento dos operadores. Mesmo assim, a utilização da barra de luz como guia para aplicações em faixas paralelas, apresentou menor erro de deslocamento durante o percurso e foi sensível à velocidade, decrescendo o erro com o aumento da velocidade de 2,20 para $3,75 \mathrm{~m} \mathrm{~s}^{-1}$. Já sem o sistema de orientação, os erros de percurso resultaram em menor largura efetiva de trabalho, agravando-se ainda mais à velocidade mais baixa.

Ambos os sistemas apresentaram erros bastante elevados. Como consequência, foram observadas grandes variações no coeficiente de variação das faixas de aplicação comprometendo em muito a qualidade das aplicações.

Um maior treinamento dos operadores e configuração mais adequada da barra de luz devem produzir melhores resultados. 


\section{REFERÊNCIAS BIBLIOGRÁFICAS}

ALCARDE, J. C. A avaliação da qualidade dos corretivos da acidez do solo. Piracicaba, ESALQ/USP. 1985. 26p.

ALMEIDA, D. L.; DE-POLli, H.; PESSANHA, G. G.; SOBRINHO, N. M. B. A. Adubação nitrogenada nos Estados do Rio de Janeiro e Espírito Santo. In: XVI Reunião Brasileira de Fertilidade do Solo, Ilhéus, BA. 1985. Anais. Ilhéus, BA. 1985. $290 \mathrm{p}$.

ANDERSON, A. C.; MACHADO, T. L. A.; MACHADO, T. L. R. Simulação computacional de fertilizantes, corretivos e sementes. In: XIX Congresso Brasileiro de Engenharia Agrícola. Piracicaba, S.P., v.2, 1990. Anais. Piracicaba.

ANGHINONI, I. Adubação nitrogenada nos Estados do Rio Grande do Sul e Santa Catarina. In: XVI Reunião Brasileira de Fertilidade do Solo, Ilhéus, BA. 1985. Anais. Ilhéus, BA. 1985290 p.

ARDILA, M. J. An Appealing Alternative: Aerial Guidance over Colombia's Banana Field. Precision Farming, December 1996. p. 10-15.

BALASTREIRE, L. A. \& COELHO, J. L. D. Aplicação Mecanizada de Fertilizantes e Corretivos. Boletim Técnico $\mathbf{n}^{\circ}$ 7. ANDA (Associação Nacional para Difusão de Adubos e Corretivos Agrícolas. São Paulo. 1992. 
BALASTREIRE, L. A. Aplicação Localizada de Insumos - ALI: Um velho conceito novo. In: Congresso Brasileiro de Engenharia Agrícola, 23.; Anais. Campinas: Unicamp, 1994. p. 248.

BALASTREIRE, L. A.; EliAS, A. I.; AMARAL, Jr. R. do. Agricultura de Precisão: Mapeamento da Produtividade do Milho. Engenharia Rural, Piracicaba. 8(1): 97 111. Julho 1997.

BAlastreire, L. A. Potencial de Utilização dos Conceitos de Agricultura de Precisão na Cultura da Cana-de-Açúcar. STAB, Açúcar, Álcool e Subprodutos. V.16. n.4, março-abril 1998a. p. 22-26.

BALASTREIRE, L. A. Agricultura de precisão. Piracicaba, 1998b. -p.: il

BALSARI, P. TAMAGNONE, M. An Automatic Spray Control For Airblast Sprayers: First Results. In: Precision Agriculture'97. v.I: Spatial Variability in Soil and Crop. Papers presented at the first European Conference on Precision Agriculture Wareick University Conference Centre, UK 7-1 September. p. 619-626. 1997.

BELLINGIERI, P. A., ALCARDE, J. M.; \& SOUZA, E. C. A de. Eficiência Relativa de Diferentes Frações Granulométricas de Calcário na Neutralização da Acidez dos Solos, Avaliados em Laborartório. Anais. Escola Superior de Agricultura "Luiz de Queiroz". Piracicaba. v.46, n.2, p. 303-317. 1989.

BELLINGIERI, P. A.; SOUZA, E. C. A.; ALCARDE, J. C.; SHIKASHO, H. W. Importância da reatividade de calcário sobre a produção de algumas características da cultura da soja. Scientia Agrícola, Piracicaba, S.P., 49(1): 61-71, 1992. 
BRAGA, J. M. Aspectos Qualitativos do Calcário. Informe Agropecuário, Belo Horizonte, v.15, n.170, p. 5-11, 1991.

BUICK, R. How Precise are Parallel Swathing Systems? Modern Agriculture. 1998. p.32-34.

CAMARGO, J. R. V.; DULlEY, R. D.; CHABARIBERY, D.; ASSUMPÇÃO, R. \& RIBEIRO, Jr. D. Estimativa de custo operacional e coeficientes técnicos da principais explorações agropecuárias do Estado de São Paulo, safra 1981/82. Informe Econômico. São Paulo, 11(7):19-101, 1981.

CAMPOS, H. de. Estatística aplicada à experimentação com cana-de-açúcar. Piracicaba: FEALQ, 1984. 292 p.

CARVALHO, V. D.; CHALFOUN, S. M. A importância do cálcio na agricultura. Informe Agropecuário, Belo Horizonte, v.15, n.170, p. 17-28, 1991.

COELHO, J. L. D.; MOLIN, J. P.; GADANHA Jr., C. D. In: II Seminário sobre uso do gesso na agricultura, Uberaba MG, INSTITUTO BRASILEIRO DO FOSFATO BRAFOS. 1992. Anais. Uberaba, MG, 1992. p. 83-103.

COLWELL, J. D. Modelos estatísticos gerais para o desenvolvimento da agricultura de baixos insumos. In: XVI Reunião Brasileira de Fertilidade do Solo, Ilhéus, BA, 1985. Anais. Ilhéus, BA. 1985. 290 p.

COOKE, G. W. Pesquisas dos fatores que limitam os rendimentos e sua importância no sistema de desenvolvimento de sistemas agrícolas. In: XVI Reunião Brasileira de Fertilidade do Solo, Ilhéus, BA. 1985. Anais. Ilhéus, BA. 1985. 290 p. 
DALLMEYER, A. U. Desenvolvimento de um rotor cônico para distribuição centrífuga de calcário seco. Santa Maria - RS, 1985. 103 p. Dissertação (Mestrado) Universidade Federal de Santa Maria.

DELAFOSSE, R. M.; BOGLIAN, M. P. Fertilizadoras centrifugas: la importancia de uma correcta eleccíon, uso y mantenimiento. Santiago, Chile, Oficina Regional de la FAO para America Latina y el Caribe, 1989. 32p.

ENGLAND, R. A.; AUDSLEY, E. On the use of the coefficient of variation as a measure of fertiliser distribuition performance. Div. Note DN 1385, AFRC Institute of Engeneering Research. Silsoe, UK. 1987.

FEKETE, A. Analysis of location error. In: Precision Agriculture'97. v.I: Spatial Variability in Soil and Crop. Papers presented at the first European Conference on Precision Agriculture Wareick University Conference Centre, September. p. 559-565. 1997.

FRANÇA, G. E.; FILHO, A. F. C. B.; VASCONCELLOS, C. A.; SANTOS, H. L. Adubação nitrogenada nos Estados de Minas Gerais. In: XVI Reunião Brasileira de Fertilidade do Solo, Ilhéus, BA. 1985. Anais. Ilhéus, BA. 1985. 290 p.

FONTANA, C.; SOUZA, J. M. de.; DALLMEYER, A. U. Uniformidade de semeadura de añoz com um distribuidor centrifugo. Centro de Ciências Rurais, Santa Maria, 15(3): 219-230. 1985.

GADANHA Jr., C. D.; MOLIN, J. P.; COELHO, J. L. D. Máquinas e Implementos Agrícolas do Brasil. São Paulo, NSI - MA, 1991.468 p. 
HAN, S.; HUMMEL, J. W.; GOERING, C.E.; CAHN, M.D. Cell size selection for sitespecific crop management. Tansactions of the ASAE, v.37, n.1, p.16-26, Jan./Feb. 1994.

HOFSTEE, J. W.; HUISMAN, W. Handling and Spreading of Fertilizers Part 1: Physical Properties of Fertilizer in Relation to Particle Motion. Journal of Agricultural Engineering Research, Wageningen, v. 47, p. 213-234. 1990.

HOFSTEE, J. W. Handling and Spreading of Fertilizers Part 2: Physical Properties of Fertilizer, Measuring Methods and Data. Journal of Agricultural Engineering Research, Wageningen, v. 53, p. 141-162. 1992.

HOFSTEE, J. W.; HUISMAN, W. Handling and Spreading of Fertilizers Part 3: Measurement of Particle Velocities and Directions with Ultrasonic Transducers, Theory, Measurement System, and experimental Arrangements. Journal of Agricultural Engineering Research, Wageningen, v. 58, p. 1-16. 1994.

HOFSTEE, J. W.; HUISMAN, W. Handling and Spreading of Fertilizers Part 5: The Spinning Disc Type Fertilizer Spreader. Journal of Agricultural Engineering Research, Wageningen, v. 62, p. 143-162. 1995.

KURASHI, S. A. H. et al. Código de avaliação de semeadoras e/ou adubadoras, Campinas, IAC, Série Documentos, 1986, 138 p.

INTERNATIONAL ORGANIZATION FOR STANDARDIZATION. Equipament for distributing fertilizer test methods - Part 1: Full width fertilizer distributors. Géneve, 1985. 5 p. (ISO 5690/1).

LONG, R. C., SELTMANN, H. Precision Application of Agricultural Chemicals. In: Precision Agriculture'97. v.I: Spatial Variability in Soil and Crop. Papers presented 
at the first European Conference on Precision Agriculture Wareick University Conference Centre, UK 7-1 September. p. 643-650. 1997.

LOPES, E. S.; DIAS, R.; FREITAS, S dos S. Influência dos microrganismos na nutrição dos cultivos nos trópicos. In: XVI Reunião Brasileira de Fertilidade do Solo, Ilhéus, BA. 1985. Anais. Ilhéus, BA. 1985. 290 p.

LUZ, P. H. C. Ensaio demonstração da determinação de faixa de deposição de corretivo do solo. In: Simpósio sobre aplicação de calcário na agricultura. Campinas, Fundação Cargill, 1986.

LUZ, P. H. C. \& TOURINO, C. Ensaio demonstração da determinação da faixa dedeposição de corretivo no solo. In: Simpósio sobre a aplicação de calcário na Agricultura, Campinas, Fundação Cargill, 1986.

LUZ, P. H. C. Máquinas para aplicação de calcário. Boletim Técnico $\mathbf{n}^{0}$ 1. Rio Claro S.P. EMBRACAL, 1989, 51 p.

MANUAL DE NSTRUÇÃO. MARCHESAN IMPLEMENTOS E MÁQUTNAS AGRÍCOLAS “TATU” S.A. 33 p.

MIALHE, L. G. Características das máquinas distribuidoras de calcário de fabricação nacional. In: Simpósio sobre aplicação de calcário na agricultura, Campinas, Fundação Cargill, 1986.

MLALHE, L. G. Máquinas Agrícolas: ensaio \& certificação. Piracicaba, S.P. Fundação de Estudos Agrários Luiz de Queiroz, 1996. 722 p. 
MILAN, M. \& GADANHA Jr., C. D. Máquinas Agrícolas: ensaio \& certificação. In:Máquinas para aplicação de adubos e corretivos. Capítulo 10, 1996, FEALQ, Piracicaba, S.P.

MOLIN, J.P. Aplicadores de calcário. Piracicaba, ESALQ, Apostila mimeogr., 1991, $\mathrm{n} / \mathrm{p}$.

MOLIN, J.P.; COELHO, J. L. D.; VASARHELYI, A. Programa computacional para análise de distribuição transversal em aplicadores de fertilizantes e corretivos a lanço. In: XXI Congresso Brasileiro de Engenharia Agrícola e I Simpósio de Engenharia Agrícola do Cone Sul, Santa Maria, 1992. 4v. em 5: il. Anais. Santa Maria, 1992.

MOLIN, J. P. Agricultura de Precisão - mais um desafio para o agricultor brasileiro. Revista Plantio Direto, n.39, p. 26-27. Maio-Junho 1997.

MOLIN, J. P. Utilização de GPS em Agricultura de Precisão. Engenharia Agrícola, Jaboticabal, v.17, n.3. p.121-132, Março 1998a.

MOLIN, J. P. Análise comparativa de sistemas de orientação com DGPS e com Bandeiras para aeronaves agricolas. In: XXVII Congresso Brasileiro de Engenharia Agrícola. Anais. Poços de Caldas: SBEA/UFLA. v.3, p. 64-66. 1998b.

PARISH, R. L. Pattem skewing with a pendulum spreader. St. Joseph: ASAE, 1995a. 6 p. (ASAE Paper 951303).

PARISH, R. L. Estimating effective swath width with a pendulum spreader. St. Joseph: ASAE, 1995b. 7 p. (ASAE Paper 951304).

PARISH, R. L. Particle Size Effects on Collection Efficiency Acroos Spreader Pattern Test. Applied Engeneering in Agriculture, 12(5): 527-529. 1996. 
PERES, J. R. R. \& SUHET, A. R. Adubação nitrogenada no Planalto Central. In: XVI Reunião Brasileira de Fertilidade do Solo, Ilhéus, BA. 1985. Anais. Ilhéus, BA. 1985. $290 \mathrm{p}$.

PIMENTEL, F. G. Curso de estatística experimental. 12 ed. Piracicaba: Livraria Nobel, 1987. 467 p.

PIMENTEL, F. G. O índice de variação, um substitutivo vantajoso do coeficiente de variação. Piracicaba: IPEF, 1991. 4 p. (Circular técnica, 178).

QUAGGIO, J. A. Método de aplicação do calcário em algumas culturas anuais e perenes. Trabalhos Apresentados. In: Simpósio Sobre Aplicação de Calcário na Agricultura, Ipanema, Fundação Cargill, 1986. i 123 p.

RAIJ, B. V. Avaliação de fertilidade do solo. Piracicaba, Instituto da Potassa e Fosfato e Instituto Internacional da Potassa, 1981. 142 p.

SILVA, L. C. F.; FILHO, J. O.; LAVORENTI, N. A.; MANOEL, L. A. Efeito de Diferentes Tipos de Calcário em Alguma Propriedades Químicas do Solo. STAB. Março/Junho 1991. p. 16-21.

SILVA, N. F. da.; CARDOSO. Jr., M. M. BALASTREIRE, L. A. Distribuidor Oscilante de Fertilizantes: Simulação de Desempenho. Engenharia Rural, Piracicaba, 1(2): 66-21, Dez, 1990.

SIQUEIRA, O. J. F. de. Adubação e Calagem: uma proposta de uso racional. Lavoura Arrozeira, Porto Alegre, 42(383), Jan.Fev. 1989. p. 13-22.

SPUGNOLI, P.; VIERI, M. ZOLI, M. Testing of spreaders for granular fertilizer. Agricultural Engineering, v.3, A. A. Balkema, Rotterdam, 1989. 
STAFFORD, J. V. Essential technology for precision agriculture. In: INTERNATIONAL CONFERENCE ON PRECISION AGRICULTURE, 3., Minneapolis, 1996. Precision Agriculture: proceedings. Madison: ASA, CSSA; SSSA; 1996, p. 595-604.

TOURINO, M. C. C. A semente no lugar certo. A Granja. - Junho 1986. p. 36-40.

VETTER, A.A. Quantitative Evaluation of DGPS Guidance for Ground-Based Agricultural Applications. Applied Engeneering in Agriculture. American Society of Agricultural Engineers. v:1 1(3): 459-464. 1995.

VETTER, A.A. Quantitative Evaluation of DGPS Guidance for Arial Agricultural Applications. Applied Engeneering in Agriculture. American Society of Agricultural Engineers. v:12(5): 611-616. 1996.

VETTORAZZI, C. A.; ANGUlO, $F^{\circ}$. R.; COUTO, H. T. Z. Sistemas de Posicionamento Global - GPS. Engenharia Rural, Piracicaba - S.P. 5(2): 61-70. 1994.

WHITNEY, R. W.; SOLIE, J. B.\& BRODER, M. F. Measuaring dynamic deposition patterns of pneumatic granular applicators. Applied Engeneering in Agriculture 8(2):159-164. 1992.

WHTNEY, R. W.; ROTH, L. O. \& KUHLMAN, D. K. Performance of selected granular colletors. Transactions of the ASAE. 30(2): 338-342. 1987.

YULE, I. J.; CROOKS, E. Precision Farming: the price of imperfection. Landwards, Spring. 1996. p.5-9. 
ZUYDAM, R. P. V., WERKHOVEN, C. High - accuracy remote position fix and guidance of moving implements in the open field: Test on sensor accuracy. In: Precision Agriculture'97. v.I: Spatial Variability in Soil and Crop. Papers presented at the first European Conference on Precision Agriculture Wareick University Conference Centre, UK 7-1 September. p. 611-618. 1997. 
APÊNDICE 
TABELA 14. Caracterização do ambiente durante realização dos ensaios.

\begin{tabular}{|c|c|c|c|c|c|c|}
\hline \multicolumn{3}{|c|}{ Ensaio com calcánio } & \multicolumn{2}{|c|}{ Tempertura } & \multicolumn{2}{|c|}{ Data: $17 / 02 / 1998$} \\
\hline Horário & Repetições & $\begin{array}{c}\text { Velocidade } \\
(\mathrm{m} / \mathrm{s})\end{array}$ & $\begin{array}{c}\text { Bulbo seco } \\
\left({ }^{\circ} \mathrm{C}\right)\end{array}$ & $\begin{array}{c}\text { Bulbo úmido } \\
\left({ }^{\circ} \mathrm{C}\right)\end{array}$ & $\begin{array}{l}\text { UR } \\
(\%)\end{array}$ & $\begin{array}{l}\text { Veloc. Vento } \\
(\mathrm{m} / \mathrm{s})\end{array}$ \\
\hline $08: 30$ & $\overline{11}$ & 8 & 24 & 20 & 70 & $0,2-0,3$ \\
\hline $08: 45$ & 2 & 8 & 24 & 20 & 70 & $0,3-1,2$ \\
\hline 09:00 & 3 & 8 & 24 & 20 & 70 & $0,1-0,4$ \\
\hline $09: 15$ & 4 & 8 & 24 & 20 & 70 & $0,4-0,5$ \\
\hline $09: 30$ & 1 & 13,5 & 24 & 20 & 70 & $0,3-0,6$ \\
\hline 09:45 & 2 & 13,5 & 24 & 20 & 70 & $0,2-0,5$ \\
\hline 10:00 & 3 & 13,5 & 24 & 20 & 70 & $0,0-0,1$ \\
\hline $10: 15$ & 4 & 13,5 & 24 & 20 & 70 & $0,1-0,2$ \\
\hline \multicolumn{3}{|c|}{ Ensaio com adubo granular } & \multicolumn{2}{|c|}{ Tempertura } & \multicolumn{2}{|c|}{ Data: $10 / 03 / 1998$} \\
\hline Horário & Repetições & $\begin{array}{c}\text { Velocidade } \\
(\mathrm{m} / \mathrm{s})\end{array}$ & $\begin{array}{c}\text { Bulbo seco } \\
\left({ }^{\circ} \mathrm{C}\right)\end{array}$ & $\begin{array}{c}\text { Bulbo úmido } \\
\left({ }^{\circ} \mathrm{C}\right)\end{array}$ & $\begin{array}{l}\text { UR } \\
(\%)\end{array}$ & $\begin{array}{c}\text { Veloc. Vento } \\
(\mathrm{m} / \mathrm{s})\end{array}$ \\
\hline $08: 30$ & 1 & 8 & 33 & 25 & 56 & $0,1-0,3$ \\
\hline 08:45 & 2 & 8 & 33 & 25 & 56 & $0,2-0,3$ \\
\hline 09:00 & 3 & 8 & 33 & 25 & 56 & $0,2-0,5$ \\
\hline 09:15 & 4 & 8 & 33 & 25 & 56 & $0,1-0,2$ \\
\hline 09:30 & 1 & 13,5 & 33 & 25 & 56 & $0,0-0,1$ \\
\hline $09: 45$ & 2 & 13,5 & 33 & 25 & 56 & $0,3-0,4$ \\
\hline $10: 00$ & 3 & 13,5 & 33 & 25 & 56 & $0,4-0,8$ \\
\hline 10:15 & 4 & 13,5 & 33 & 25 & 56 & $0,6-0,7$ \\
\hline \multicolumn{3}{|c|}{ Ensaio com uréia } & \multicolumn{2}{|c|}{ Tempertura } & \multicolumn{2}{|c|}{ Data: $16 / 03 / 1998$} \\
\hline Horário & Repetições & $\begin{array}{c}\text { Velocidade } \\
(\mathrm{m} / \mathrm{s})\end{array}$ & $\begin{array}{c}\text { Bulbo seco } \\
\left({ }^{\circ} \mathrm{C}\right)\end{array}$ & $\begin{array}{l}\text { Bulbo úmido } \\
\left({ }^{\circ} \mathrm{C}\right)\end{array}$ & $\begin{array}{l}\text { UR } \\
(\%)\end{array}$ & $\begin{array}{c}\text { Veloc. Vento } \\
(\mathrm{m} / \mathrm{s})\end{array}$ \\
\hline $08: 30$ & 1 & 8 & 34 & 29 & 69 & $0,0-0,0$ \\
\hline $08: 45$ & 2 & 8 & 34 & 29 & 69 & $0,0-0,0$ \\
\hline 09:00 & 3 & 8 & 34 & 29 & 69 & $0,0-0,1$ \\
\hline 09:15 & 4 & 8 & 34 & 29 & 69 & $0,1-0,1$ \\
\hline 09:30 & 1 & 13,5 & 34 & 29 & 69 & $0,0-0,0$ \\
\hline 09:45 & 2 & 13,5 & 34 & 29 & 69 & $0,0-0,0$ \\
\hline $10: 00$ & 3 & 13,5 & 34 & 29 & 69 & $0,0-0,1$ \\
\hline $10: 15$ & 4 & 13,5 & 34 & 29 & 69 & $0,0-0,2$ \\
\hline \multicolumn{3}{|c|}{ Ensaio com aveia } & \multicolumn{2}{|c|}{ Tempertura } & \multicolumn{2}{|c|}{ Data: $24 / 03 / 1998$} \\
\hline Horário & Repetições & $\begin{array}{c}\text { Velocidade } \\
(\mathrm{m} / \mathrm{s})\end{array}$ & $\begin{array}{c}\text { Bulbo seco } \\
\left({ }^{\circ} \mathrm{C}\right)\end{array}$ & $\begin{array}{c}\text { Bulbo úmido } \\
\left({ }^{\circ} \mathrm{C}\right)\end{array}$ & $\begin{array}{l}\text { UR } \\
(\%)\end{array}$ & $\begin{array}{c}\text { Veloc. Vento } \\
(\mathrm{m} / \mathrm{s})\end{array}$ \\
\hline $08: 30$ & 1 & 8 & 31 & 26 & 56 & $0,3-0,8$ \\
\hline $08: 45$ & 2 & 8 & 31 & 26 & 56 & $0,2-0,2$ \\
\hline 09:00 & 3 & 8 & 31 & 26 & 56 & $0,1-0,0$ \\
\hline $09: 15$ & 4 & 8 & 31 & 26 & 56 & $0,3-1,2$ \\
\hline 09:30 & 1 & 13,5 & 29 & 23 & 56 & $0,0-0,1$ \\
\hline $09: 45$ & 2 & 13,5 & 29 & 23 & 56 & $0,0-0,0$ \\
\hline $10: 00$ & 3 & 13,5 & 29 & 23 & 56 & $0,0-0,1$ \\
\hline $10: 15$ & 4 & 13,5 & 29 & 23 & 56 & $0,2-0,4$ \\
\hline
\end{tabular}


TABELA 15. Resultados das medições de deslocamento entre a linha base e a posição em que o trator passou para cada um dos tratamentos dos ensaios de percurso com sistema de orientação.

\begin{tabular}{|c|c|c|c|c|c|c|c|c|c|c|c|c|c|c|}
\hline \multicolumn{15}{|c|}{ Operador } \\
\hline & 1 & & & 2 & & & 3 & & & 4 & & & 5 & \\
\hline \multicolumn{15}{|c|}{ Velocidade de $2,20 \mathrm{~m} \mathrm{~s}^{-1}$ com DGPS } \\
\hline Rl & R2 & R3 & Rl & R2 & R3 & $\mathrm{R} 1$ & R2 & R3 & $\mathrm{R} 1$ & R2 & 23 & 1 & R2 & KJ \\
\hline 5,14 & 7,87 & 15,81 & 8,48 & 14,1 & 19,12 & 11,24 & 15,91 & 20,54 & 3,32 & 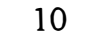 & 16,41 & 2 & 10,04 & 16,9 \\
\hline 5,2 & 8,21 & 15,19 & 7,92 & 13,27 & 18,06 & 10,34 & 16,23 & 19,94 & 6,49 & 0,87 & 16 & & 9,02 & 16,01 \\
\hline 4,99 & & 15,17 & 7,49 & 12,94 & 18,32 & 9,55 & 16,9 & 19,86 & 7,23 & & & 4 & 9,17 & \\
\hline 4,96 &, 28 & 15,51 & 7,28 & 13 & 7,7 & 8,32 & 15,79 & 18,49 & 7,86 & 98 & & 3 & 9,24 & \\
\hline 4,78 &, 89 & 15 & 7 & 3,13 & 2 & 9,29 & 15,55 & 18,3 & 8.2 & & & & 38 & \\
\hline 4,89 & 1 & 15, & 6.5 & 1 & & & 14 & 17,89 & & & & & נס & \\
\hline 4,96 & & 15 & & & & & & & & & & & & \\
\hline 4,94 & 5 & 15 & 0 & 9 & 17 & 8,78 & 12 & 17,56 & 7,61 & & & & 62 & \\
\hline 4,67 & 3 & 14 & 0,52 & 12,31 & 1 & 8,43 & 11 & 17 & 7 & & & &, 6 & \\
\hline 4,63 & 28 & 14,8 & 6,73 & 2,28 & 16 , & 7,4 & 11,74 & 17,72 & 7,56 & & & & 9,61 & \\
\hline 4,78 &, 53 & 14,86 & 6,53 & 1,73 & 17, & 6,6 & 11,49 & 18,31 & 7, & & & & 59 & \\
\hline 4,75 &, 42 & 14,5 & 63 & 1,19 & 17 & 6,2 & 11,53 & 17,65 & & & & & ,72 & \\
\hline 4,47 & 7 & 14 & 6,19 & 0,65 & 16 & & & 17, & & & & & 85 & \\
\hline 4,23 & & & & 7 & & & & & & & & & & \\
\hline 4 , & & & & & & & & & & & & & & \\
\hline 4,3 & & & & & & & & & & & & & & \\
\hline 4,3 & & 15, & 5 , & 8 & & 4,9 & 2 & 16 & 6,5 & & & & 1 & \\
\hline 4,3 & & 15, & & 97 & & $5,($ & 1 & 16 & & & & & 44 & \\
\hline 4,1 & & 15 & & 12 & & & & 15 & 0 , & & & & & \\
\hline 3,4 & & & & & & & & & & & & & & \\
\hline 3 & & & & & & & & & & & & & & \\
\hline & & & & & & & & 15 & & & & & & \\
\hline \multicolumn{15}{|c|}{ elocidade de $3,75 \mathrm{~m} \mathrm{~s}^{-1}$ com DGPS } \\
\hline 7,02 & & & & & & & & & & & & & & \\
\hline 6, & & & & & & & & 1 & & & & & & \\
\hline 6 & & 1 & & & & & & & & & & & & \\
\hline 6,1 & 5 & 16 & 5, & 1 & 1 & & 7, & & 3, & & & & & \\
\hline 5,7 & ,55 & 15 & 5, & 6 & & & 7,3 & & & & & & & \\
\hline 5,5 & 11,32 & 15 & 6,2 & 9 & & & 7 & 7 & 3, & & & & 2 & \\
\hline 5,0 & 8 & 15 & & & & & 68 & & & & & & & \\
\hline 4,5 & & 15 & & & & & & & & & & & & \\
\hline 4, & & & & & & & & & & & & & & \\
\hline & & & & & & & & & & & & & & \\
\hline & & & & & & & & & & & & & & \\
\hline 5,2 & 6 & 15 & & & & & & & & & & 5,07 & 44 & \\
\hline 5,7 & ,31 & 15 & 4 & 76 & & & $\gamma$ & 15 & & & & & 29 & 1572 \\
\hline 5,8 &, 44 & 15 & 4, & 3 & 16 & 5 & 0 & 15 & 4,59 & 11,9 & & & 5 & 29 \\
\hline 6 & 11,48 & 12 & 5 , & 6 & 1 & 5 & 9, & 1 & 4, & 4 & & 79 & 53 & \\
\hline 5,8 & & 11 & 5 & 3 & 15 & 6 & 9,92 & 15 & 4, & & & 4 & ,9 & \\
\hline 5. & 2 & 1 & & & & & & & & & & & & \\
\hline & & & & & & & & & & & & & & \\
\hline & & 15 & & & & 5 , & 10,12 & 16,74 & 5, & & & &, 47 & 16,27 \\
\hline 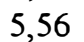 & & & 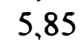 & & & 50 & & 16,85 & 6 & 13,45 & 17 & 6,3 & 9,3 & 16,91 \\
\hline
\end{tabular}


TABELA 16. Resultados das medições de deslocamento entre a linha base e a posição em que o trator passou para cada um dos tratamentos dos ensaios de percurso sem sistema de orientação.

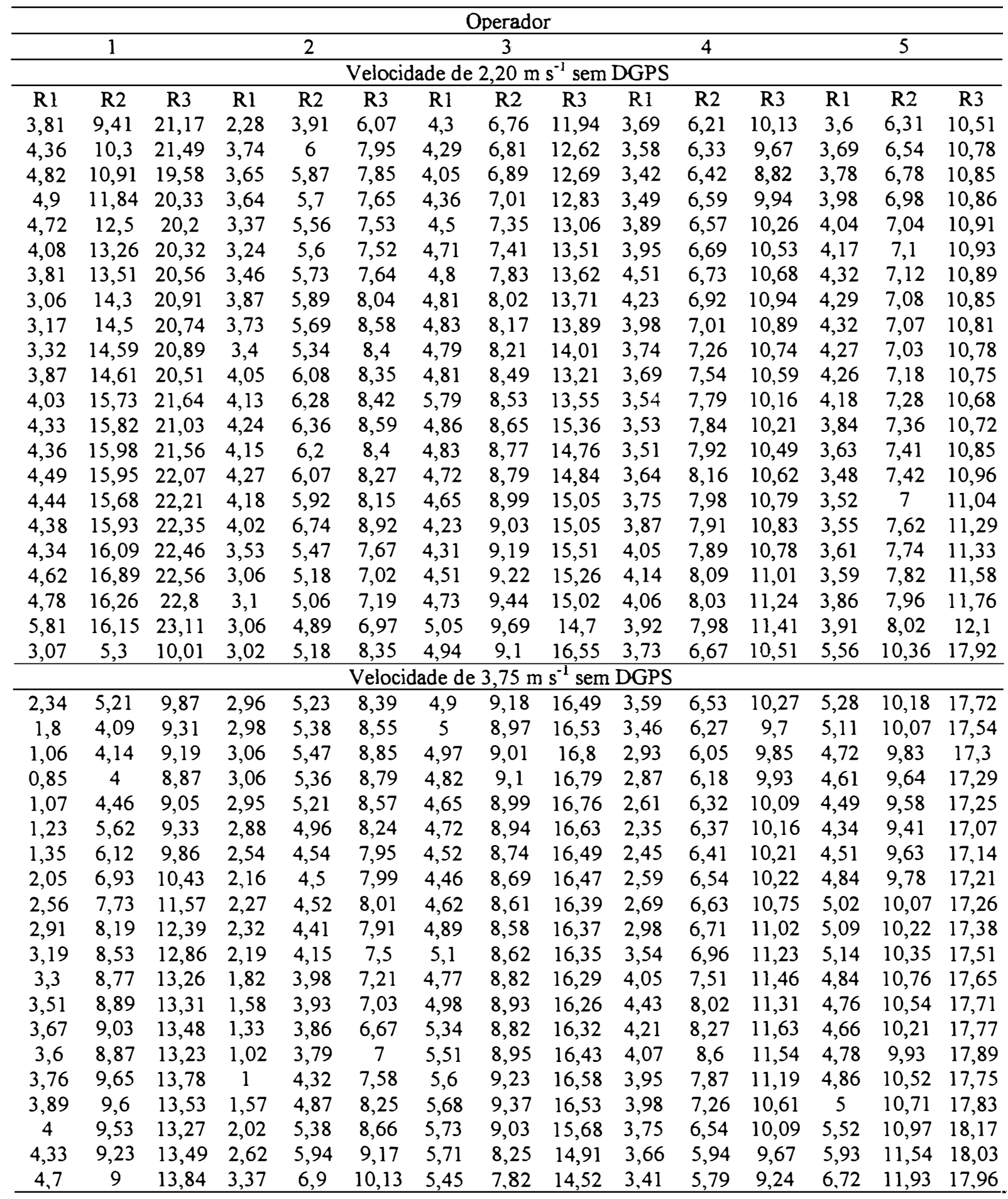


TABELA 17. Médias dos posicionamentos do trator em relação a linha base para cada tratamento no ensaio de caracterização do percurso.

\begin{tabular}{|c|c|c|c|c|c|c|c|c|c|c|c|c|c|c|c|}
\hline Tratamentos & \multicolumn{3}{|c|}{ Operador 1} & \multicolumn{3}{|c|}{ Operador 2} & \multicolumn{3}{|c|}{ Operador 3} & \multicolumn{3}{|c|}{ Operador 4} & \multicolumn{3}{|c|}{ Operador 5} \\
\hline & $\mathrm{Rl}$ & $\mathrm{R} 2$ & $\overline{\mathrm{R} 3}$ & $\mathrm{R} 1$ & $\mathrm{R} 2$ & $\overline{\mathrm{R} 3}$ & $\mathrm{R} 1$ & $\mathrm{R} 2$ & $\mathrm{R} 3$ & $\mathrm{Rl}$ & R2 & R3 & $\mathrm{R} 1$ & $\mathrm{R} 2$ & R3 \\
\hline $\begin{array}{c}2,20 \mathrm{~m} \mathrm{~s}^{-1} \mathrm{com} \\
\text { DGPS }\end{array}$ & 4,5 & 10,4 & 15,4 & 6,4 & 11,5 & 16,9 & 7,2 & 13,1 & 17,6 & 7,1 & 10,8 & 16,8 & 4,7 & 9,8 & 16,2 \\
\hline $\begin{array}{c}3,75 \mathrm{~m} \mathrm{~s}^{-1} \mathrm{com} \\
\text { DGPS }\end{array}$ & 5,7 & 11,0 & 15,0 & 5,8 & 10,9 & 15,5 & 4,9 & 8,3 & 15,4 & 4,1 & 11,2 & 15,4 & 4,8 & 9,8 & 15,3 \\
\hline $\begin{array}{c}2,20 \mathrm{~m} \mathrm{~s}^{-1} \text { sem } \\
\text { DGPS }\end{array}$ & 4,3 & 14,3 & 21,4 & 3,6 & 5,7 & 7,9 & 4,7 & 8,3 & 14,0 & 3,8 & 7,3 & 10,5 & 3,9 & 7,2 & 11,0 \\
\hline $\begin{array}{c}3,75 \mathrm{~m} \mathrm{~s}^{-3} \text { sem } \\
\text { DGPS }\end{array}$ & 2,8 & 7,3 & 11,6 & 2,3 & 4,6 & 8,1 & 5,1 & 8,9 & 16,3 & 3,4 & 6,8 & 10,5 & 5,0 & 10,3 & 17,6 \\
\hline
\end{tabular}

SEMDQS A2,20 $\mathrm{ms}^{-1}$

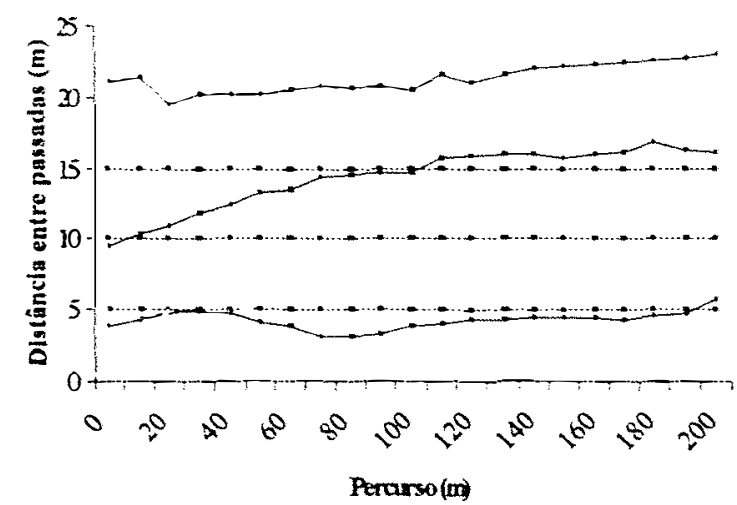

COMDGS A2,20 $\mathrm{ms}^{-1}$

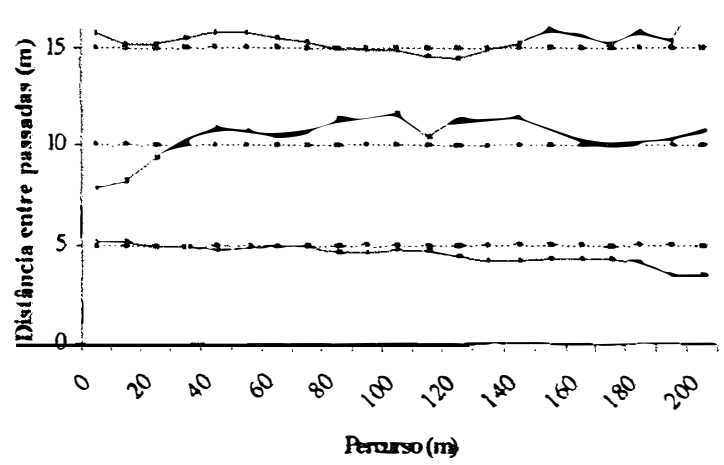

SEMDQP A3,75 ms

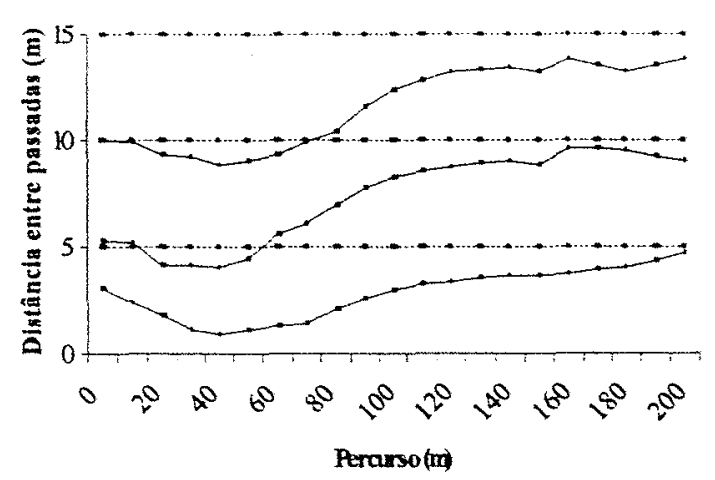

COMDCPS A3,75 ms $\mathrm{s}^{-1}$

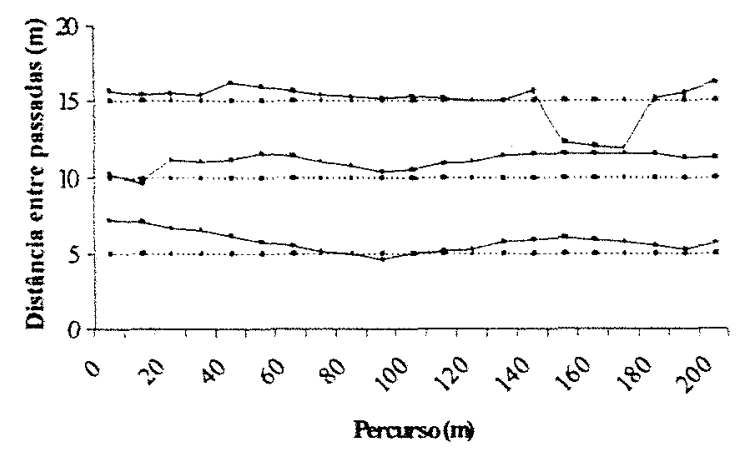

FIGURA 17. Percursos observados para o operador 1 a velocidade de deslocamento de $2,20 \mathrm{~m} \mathrm{~s}^{-1}$ e $3,75 \mathrm{~m} \mathrm{~s}^{-1}$, com e sem o uso da barra de luz. 


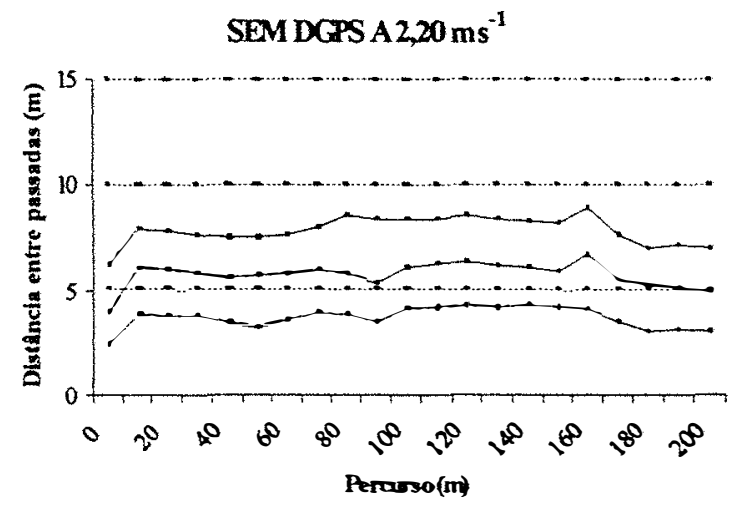

COMDGSA $2,20 \mathrm{~ms}^{-1}$

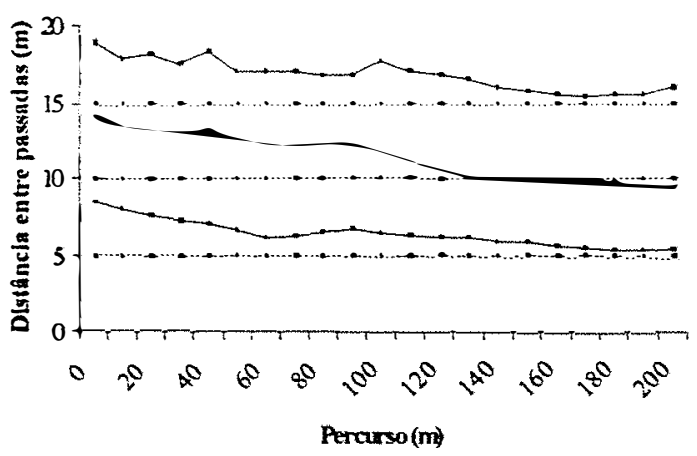

SEM DGPS A3,75 $\mathrm{ms}^{-1}$

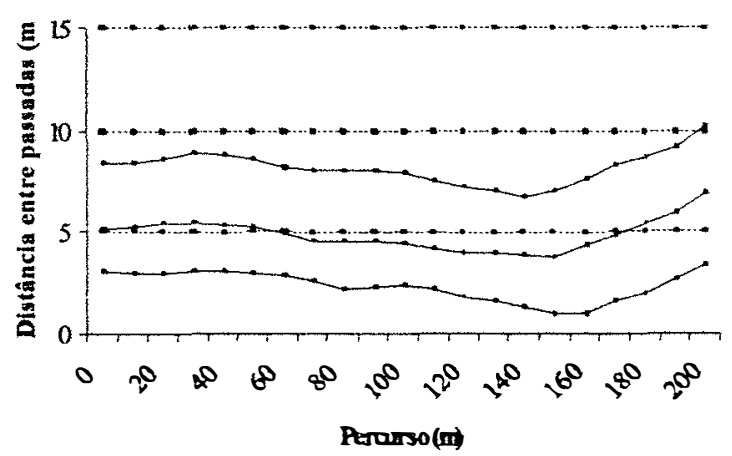

COMDGPS A3,75 $\mathrm{ms}^{-1}$

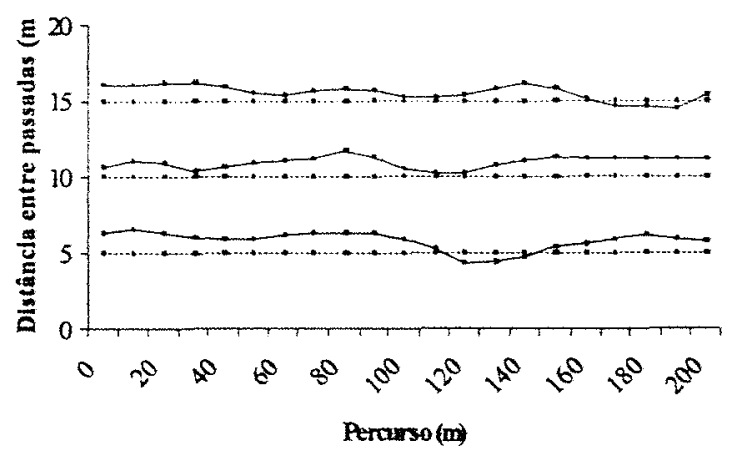

FIGURA 18. Percursos observados para o operador 2 a velocidade de deslocamento de $2,20 \mathrm{~m} \mathrm{~s}^{-1}$ e $3,75 \mathrm{~m} \mathrm{~s}^{-1}$, com e sem o uso da barra de luz. 
SEMDGPSA2,20 $\mathrm{ms}^{-1}$

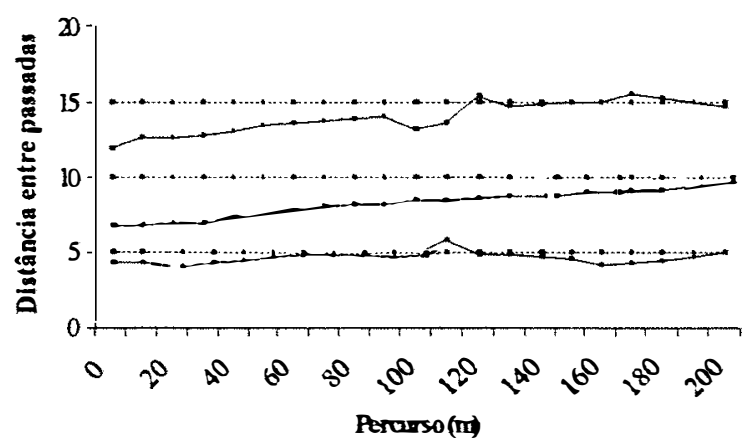

COMDGS A2,20 ms

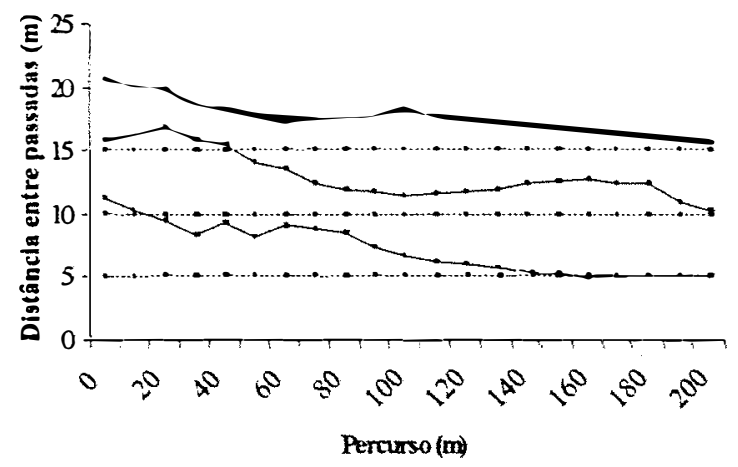

SEMDQPSA3,75 $\mathrm{ms}^{-1}$

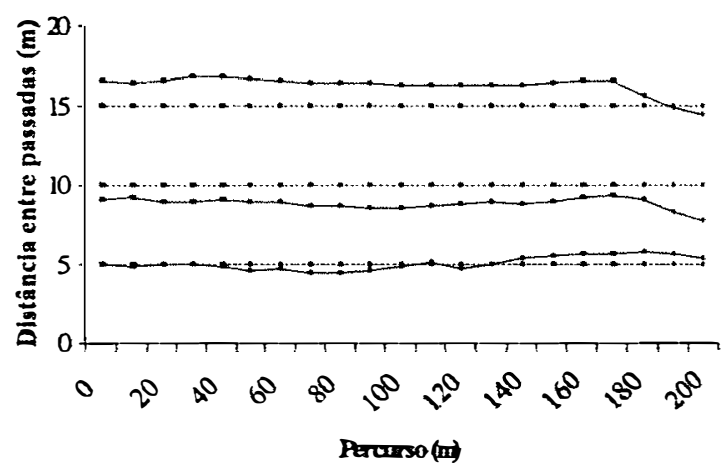

COMDGPA $3,75 \mathrm{~ms}^{-1}$

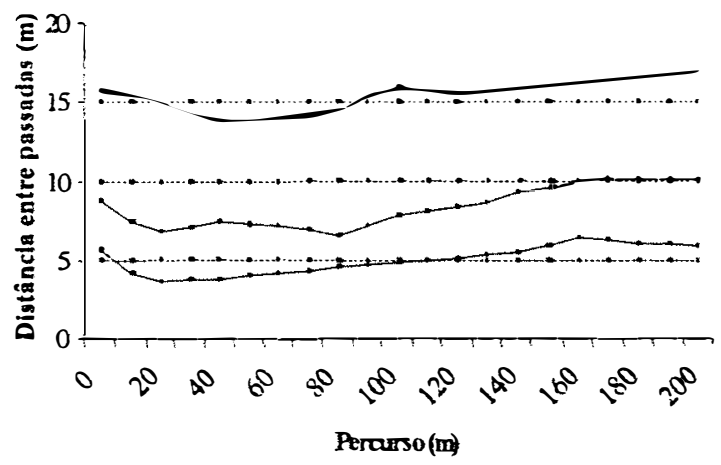

FIGURA 19. Percursos observados para o operador 3 a velocidade de deslocamento de $2,20 \mathrm{~m} \mathrm{~s}^{-1}$ e $3,75 \mathrm{~m} \mathrm{~s}^{-1}$, com e sem o uso da barra de luz. 
SEMDGS A2,20 $\mathrm{ms}^{-1}$

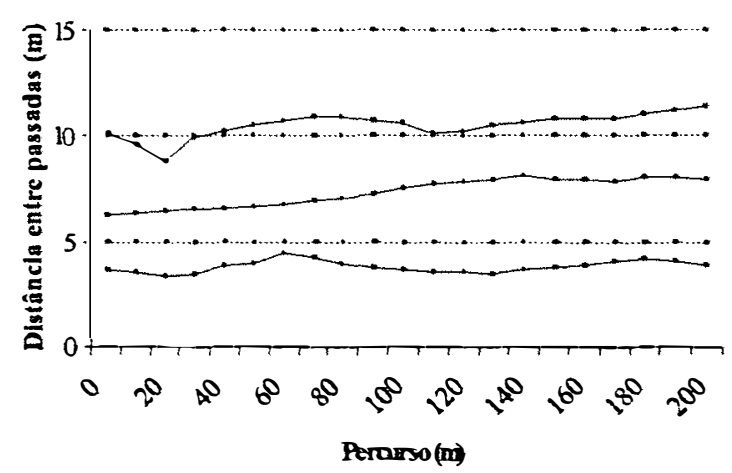

COMDCPSA2,20 $\mathrm{ms}^{-1}$

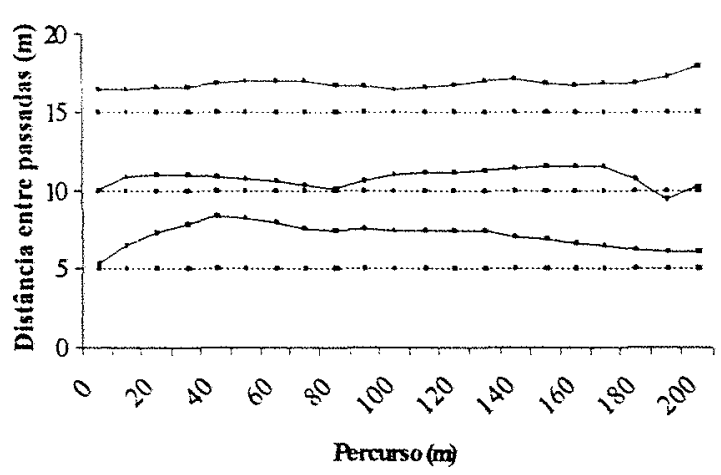

SEMDCPS A3,75 $\mathrm{ms}^{-1}$

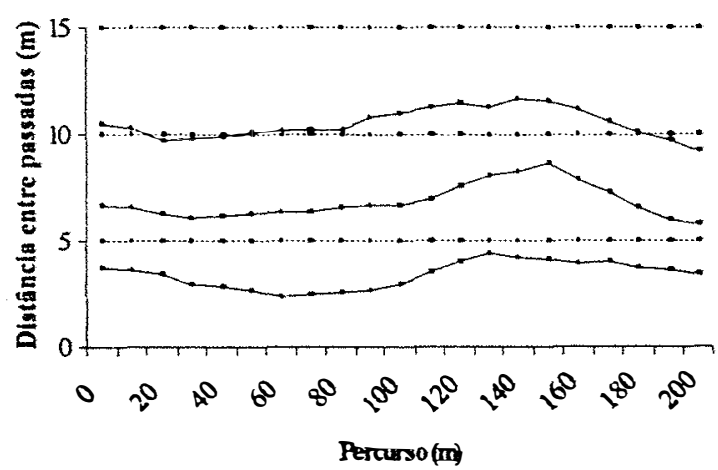

COMDASA3,75 ms

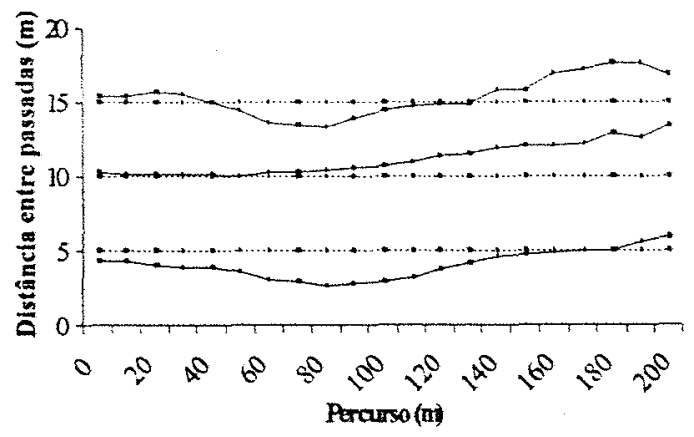

FIGURA 20. Percursos observados para o operador 4 a velocidade de deslocamento de $2,20 \mathrm{~m} \mathrm{~s}^{-1}$ e $3,75 \mathrm{~m} \mathrm{~s}^{-1}$, com e sem o uso da barra de luz. 
SEMDGPSA2,20 $\mathrm{ms}^{-1}$

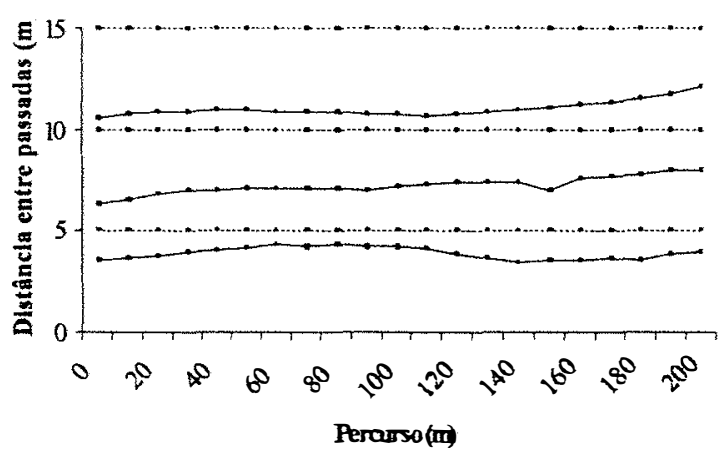

COMDGS A220 $\mathrm{ms}^{-1}$

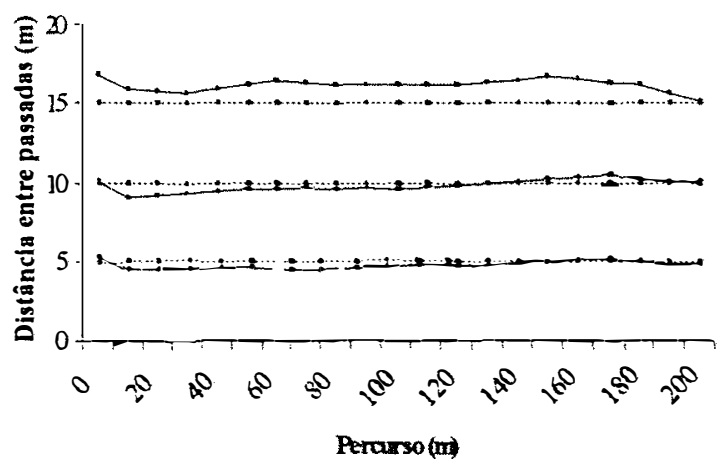

SEMDOPSA3,75 $\mathrm{m} \mathrm{s}^{-1}$

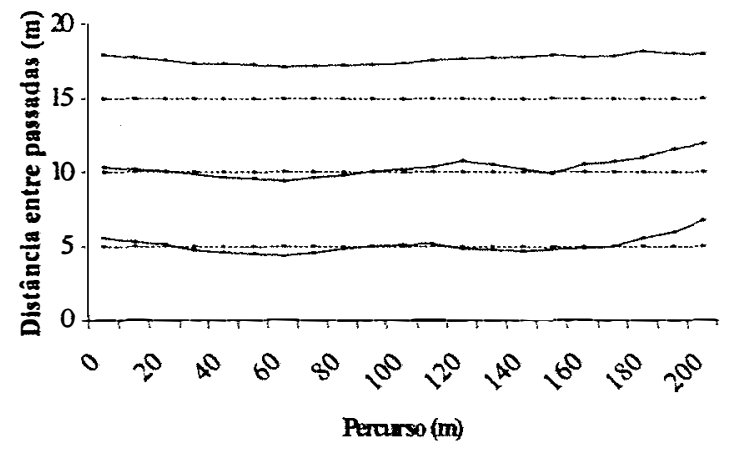

COMDASA3, $7 \mathrm{~ms}^{-1}$

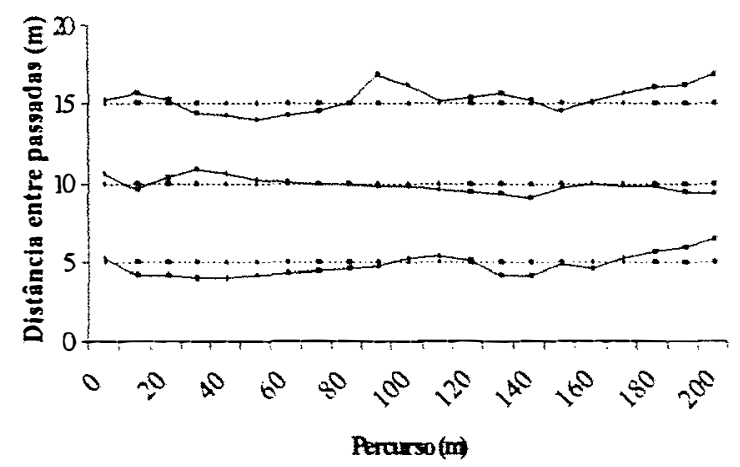

FIGURA 21. Percursos observados para o operador 5 a velocidade de deslocamento de $2,20 \mathrm{~m} \mathrm{~s}^{-1}$ e $3,75 \mathrm{~m} \mathrm{~s}^{-1}$, com e sem o uso da barra de luz. 